\title{
Análisis de una decadencia. La arqueología española del siglo XIX. II (2), La crisis de la restauración (1868-1885)
}

\author{
Analysis of a decline. The nineteenth century Spanish archaeo- \\ logy. II (2). The crisis of Restoration (1868-1885)
}

\author{
Alfredo Mederos Martín ${ }^{1}$
}

Recibido 09/06/2014

Aceptado 31/07/2014

\begin{abstract}
Resumen
Los estudios de Historia sólo adquirieron importancia en España con el Plan de Estudios de 1880, al incrementarse de 2 a 3 años la Licenciatura en Filosofía y Letras, y pasar las asignaturas de Historia del $3^{\circ}$ curso o último del Bachiller, a impartirse durante $4^{\circ}, 5^{\circ}$ y $6^{\circ}$ curso de la Licenciatura. Sin embargo, no había asignaturas específicas de Arqueología, que sólo se impartieron en la Escuela Superior de Diplomática, aunque tuvo un fuerte declive en el número de estudiantes en este periodo, con Numismática-Epigrafía y Arqueología en $2^{\circ}$ curso e Historia de las Bellas Artes en $3^{\circ}$. La institución de mayor influencia fue la Real Academia de la Historia, pero mantuvo un criterio de elección de sus miembros entre la alta sociedad, poco cualificados, y sólo un tercio de los Numerarios tenían algún grado de especialización en Historia. El cargo de Anticuario fue detentado entre 1866-94 por el crítico literario y dramaturgo, Aureliano Fernández-Guerra, lo que hizo perder influencia a la Academia en el ámbito de la Arqueología, que fue asumiendo el Museo Arqueológico Nacional, creado en 1867, pero cuya sede definitiva no fue inaugurada hasta 1892. Las Comisiones Provinciales de Monumentos Históricos y Artísticos no funcionaron adecuadamente, por el desinterés de los gobernadores civiles que presidían y convocaban las reuniones, la falta de renovación de sus miembros fallecidos y la ausencia de un Plan de General de Excavaciones de ámbito nacional. La supresión en 1868 de la Academia Real de Arqueología y Geografía del Príncipe Alfonso obligó a la burguesía aficionada a la arqueología a asociarse en sociedades de ámbito regional o provincial. El control académico de la arqueología fue detentado por un grupo granadino encabezado por Fernández-Guerra, junto con Rada y Riaño. Los arqueólogos más importantes de este periodo fueron Juan de Dios de la Rada, catedrático de Numismática y Epigrafía (1856-1900), director de la Escuela Superior de Diplomática (1876-1900) y del Museo Arqueológico Nacional (1891-1900) y Juan Vilanova, catedrático de Geología y Paleontología (1854-93), pero sus trayectorias científicas se vieron afectadas por duras polémicas de alcance internacional. Rada debido a la presencia de falsificaciones en su estudio de las esculturas ibéricas del Cerro de los Santos y Vilanova por su defensa de las posturas creacionistas frente a los darwinistas y del origen paleolítico de las pinturas rupestres de la Cueva de Altamira.
\end{abstract}

Palabras clave: arqueología española, siglo XIX, historiografía, arqueología monumental, darwinismo.

\begin{abstract}
The study of History only became important in Spain with the University Study Plan of 1880, with the increase of 2 to 3 years in the Degree of Arts, and the transfer of the subjects of History from the 3rd year or last in the High School, to span during 4, 5th and 6th year in the Degree or Bachelor of Arts. However, there was not specific subject of Archaeology, which was only taught at the Highest Diplomatic School, but had a sharp decline in the number of stu-
\end{abstract}

1 Departamento de Prehistoria y Arqueología, Facultad de Filosofía y Letras, Universidad Autónoma de Madrid,
Campus de Cantoblanco, 28.049 Madrid. Email: alfredo.mederos@uam.es 
dents during this period, with Numismatic-Epigraphy and Archaeology in 2nd year and History of Fine Arts in 3rd year. The most influential institution was the Royal Academy of History, but maintained a criterion of choice high society lowskilled members and only a third of the fellows had some degree of specialization in History. The Antiquarian was held, between 1866-1894, by the literary critic and playwright, Aureliano Fernández-Guerra, who made lost influence to the Academy in the field of Archaeology, which was assumed by the National Archaeological Museum, established in 1867, but whose permanent headquarters was not opened until 1892. The Provincial Commissions of Historical and Artistic Monuments did not work properly, because the lack of interes of the civil governors that presided and convened the meetings, the non-renewal of its deceased members and the absence of a General Plan of Excavations nationwide. The abolition in 1868 of the Royal Academy of Archaeology and Geography of Prince Alfonso forced to the bourgeoisie to create regional or provincial archaeological societies. The academic control in the field of Archaeology was held by a group headed by Fernandez-Guerra, along with Rada and Riaño, all from Granada. The most important archaeologists of this period were Juan de Dios de la Rada, Professor of Numismatics and Epigraphy (1856-1900), director of the Highest Diplomatic School (1876-1900) and the National Archaeological Museum (1891$1900)$ and Juan Vilanova, Professor of Geology and Palaeontology (1854-93), but their scientific careers were affected by bitter controversies of international scope. Rada due to the presence of forgeries in his study of Iberian sculptures of Cerro de los Santos and Vilanova for defending creationist positions against Darwinists and the Palaeolithic origin of the cave paintings of Altamira.

Key words: Spanish archaeology, nineteenth century, historiography, monumental archaeology, Darwinism.

\section{RENÉ VERNEAU Y LA INTRODUCCIÓN DE LOS ESTU- dios raciales: El hombre de Cro-Magnon en la Península Ibérica y las Islas Canarias}

En 1868 se descubrió durante la construcción de la estación de ferrocarril de Les Ezieres el Abric CroMagnon, situado en el Valle del río Vézère (Les Ezieres de Tayac, Dordoña, Francia). Excavado por Louis Lartet, se localizó restos de Homo sapiens, incluyendo 3 hombres, 1 mujer y 1 feto, actualmente fechados hacia el 28.000 AC, dentro del Gravetiense. El cráneo más característico fue el de un hombre adulto de ca. 50 años, denominado por Broca (1868a y 1868b) "el viejo", con gran capacidad craneal, 1590 $\mathrm{cm}^{3}$, frente ancha, órbitas rectangulares, mentón marcado y $1.82 \mathrm{~m}$. altura.

Después de observar Broca (1868b) cráneos procedentes de Barranco Hondo (El Rosario, Tenerife), presentes en la colección Bouglinval de París, los identificó como del tipo Cro-Magnon. El dato, confirmado por Hamy, sirvió para que Quatrefages y Hamy (1874) definieran la raza de Cro-Magnon en La race de CroMagnon dans l'espace et dans le temps, con cara corta, ancha y cráneo alargado dolicéfalo. Para confirmarlo, por una parte Jean Louis Armand de Quatrefages de Breu, catedrático de Antropología y Etnografía en el Museo de Historia Natural de París (1855-92), solicitó en 1873 más cráneos al cónsul francés en Tenerife, Sabin Berthelot (1879/1980: 129 n. 1), que le remitió 10 nuevos en 1876.

Por otra parte, encargó al médico René Verneau, preparador en su cátedra desde 1873, que había sido alumno libre de Antropología en las clases de ErnestThéodore Hamy en La Sorbonne, después alumno suyo en sus clases en el Muséum national d'Histoire naturelle, y con experiencia de trabajar con Broca en su laboratorio, que marchase a las Islas Canarias a realizar una investigación de campo para confirmar estos datos.

Para Quatrefages, según le comentó por carta en 1873 a Berthelot (1879/1980: 129), "las investigaciones craneológicas parecen indicar una filiación entre los guanches y una de las razas que poblaron en otro tiempo el mediodía francés". Berthelot le envió 3 cráneos de una cueva del Barranco de Agua de Dios (Tegueste, Tenerife), uno de ellos momificado. También 4 cráneos de Gran Canaria, de tres procedencias, un túmulo de La Isleta (Las Palmas de Gran Canaria), otro de la Cueva de los Huesos en Tafira (Las Palmas de Gran Canaria) y dos de una cueva del Barranco de Guayadeque (Ingenio, Gran Canaria). Además, 3 cráneos de la Cueva de Los Letreros de El Julan (Frontera, El Hierro). Según la interpretación de Quatrefages y Verneau, los nuevos cráneos indicaban la presencia de más razas, incluyendo la coexistencia de una raza semita tanto en El Hierro como Gran Canaria (Berthelot, 1879/1980: 129-130).

René Verneau fue enviado entre el 22 de marzo de 1876 hasta finales de 1878 a una misión científica en las Islas Canarias, Rapport sur une mission scientifique dans l'Archipiel Canarien (Verneau, 1887), siendo nombrado a su vuelta conservador del Muséum national d'Histoire naturelle de París desde 1879. Regresó en septiembre de 1884 hasta avanzado 1887, recorriendo detalladamente todas las islas, publicando una monografía Cinq années de sejour aux Iles Canaries (Verneau, 1891/1981: 9) y en particular el artículo La race de Cro-Magnon. Ses migrations, ses descendants (Verneau, 1886), redactado cuando estaba aún en las islas (fig. 1). 


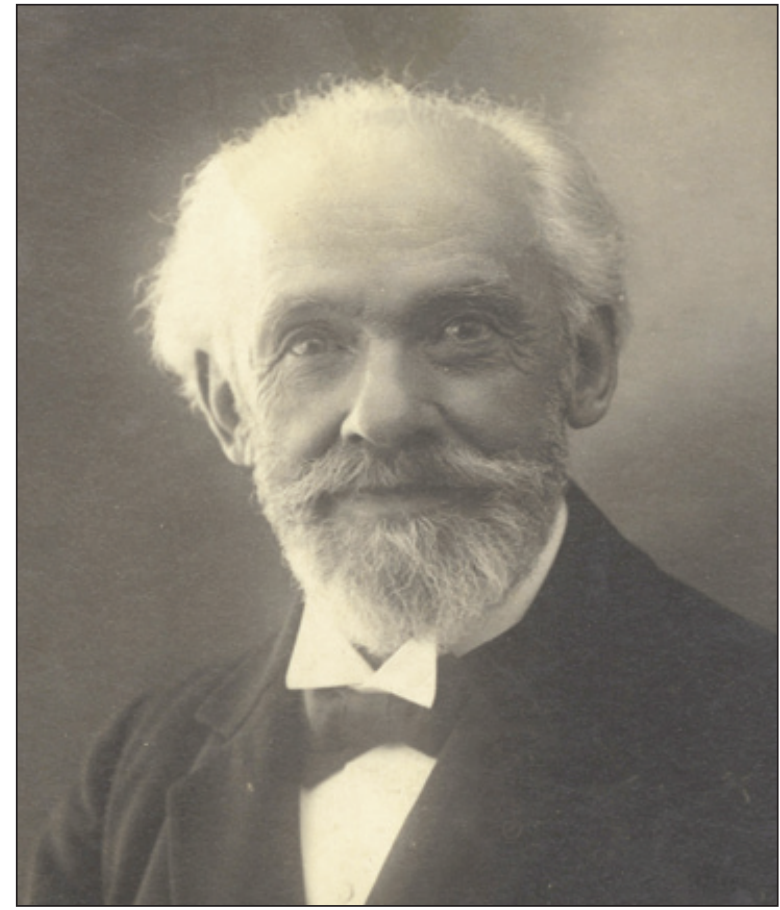

Figura 1. René Verneau. El Museo Canario.

A partir del estudio de los cráneos planteó una expansión del H. sapiens Cro-Magnon desde el Sur de Francia hacia las Islas Canarias. "Llegó al norte de África después de haber atravesado España y quizás Italia, donde se pueden seguir sus huellas hasta la Terre de Labour. Las Islas Canarias serían la última etapa de los viejos cazadores de la Vézère (...) y franquearan en embarcaciones la poca distancia que separa Marruecos del archipiélago canario". Otra ruta terrestre iría hacia el Este, desde Marruecos hacia Argelia, de acuerdo con su interpretación de los cráneos de la necrópolis megalítica de Roknia (Argelia), hasta alcanzar Túnez (Verneau, 1886/1996: 25).

Además, consideraba que se trataban de pobladores rubios con los ojos claros. "Los guanches, que indiscutiblemente vivieron en las cinco islas que hasta ahora hemos estudiado, presentaban todos los rasgos del hombre cuaternario de la Vézère (...) Como los cabilas de los que hemos hablado [de Beni-Menasser, Djurdjura y Denhadja], tienen los cabellos rubios y los ojos azules" (Verneau, 1886/1996: 24). "Todas las poblaciones de las que hemos hablado empleaban para sus muertos el mismo modo de sepultura (cuevas sepulcrales o dólmenes). Esta costumbre estable, pues, un nuevo lazo de unión entre los trogloditas de la Vézère, los hombres neolíticos de España, los antiguos rubios de Roknia, los del resto de Argelia y de Marruecos y los antiguos guanches de las Islas Canarias". En conclusión, "Los rubios del Norte [de África] del general Faidherbe, los celtas primitivos de Henri Martin, los constructores de los dólmenes africanos, 'esos hombres rubios que de la Galia pasaron a España y desde allí, sin duda, a África', no serían, pues, sino los descendientes de nuestros cazadores cuaternarios del valle de la Vézère" (Verneau, 1886/1996: 24-25, 27).

Para algún autor como Farrujia (2004: 270, 274 y 2005), esta publicación de 1886 pudo ser una consecuencia del Congreso de Berlín de 1884-85, cuando se endureció el conflicto por el reparto colonial, y la tesis de Verneau, defensor de un origen francés de la raza de Cro-Magnon, a su juicio implicaba que "Su presencia en el norte de África y Canarias legitimaba su anexión" francesa.

\section{Marcelino Sanz de Sautuola y el Descubri- MIENTO DEL ARTE RUPESTRE PALEOLÍTICO}

Marcelino Sanz de Sautuola y Pedrueca nació el 2 de junio de 1831, hijo único del burgalés Santiago Sanz de Sautuola, alcalde de Santander entre 1859-62, y la santanderina Gertrudis Pedrueca y Velarde. Cursó el bachillerato hasta 1848 en el Instituto Provincial de Segunda Enseñanza de Santander, trasladándose después a la Universidad Literaria de Valladolid a estudiar primero el curso de Ampliación de Filosofía en 184849 y luego la carrera de Derecho entre 1849-53, llegando a ser secretario del Gobierno Civil y diputado por Torrelavega en 1880 (Madariaga, 2004: 19-21, 26$27,38)$. Se encargó de administrar los bienes de su tío, el asturiano José de Posada Herrera (Madariaga, 2004: 35), diputado por Torrelavega y Santander entre 185771, adscrito al Partido Moderado, llegando a ser Ministro de Gobernación en 1858 y 1865, Presidente del Congreso de Diputados en 1876 y Presidente del Gobierno entre 1883-84 representando a Izquierda Dinástica (fig. 2).

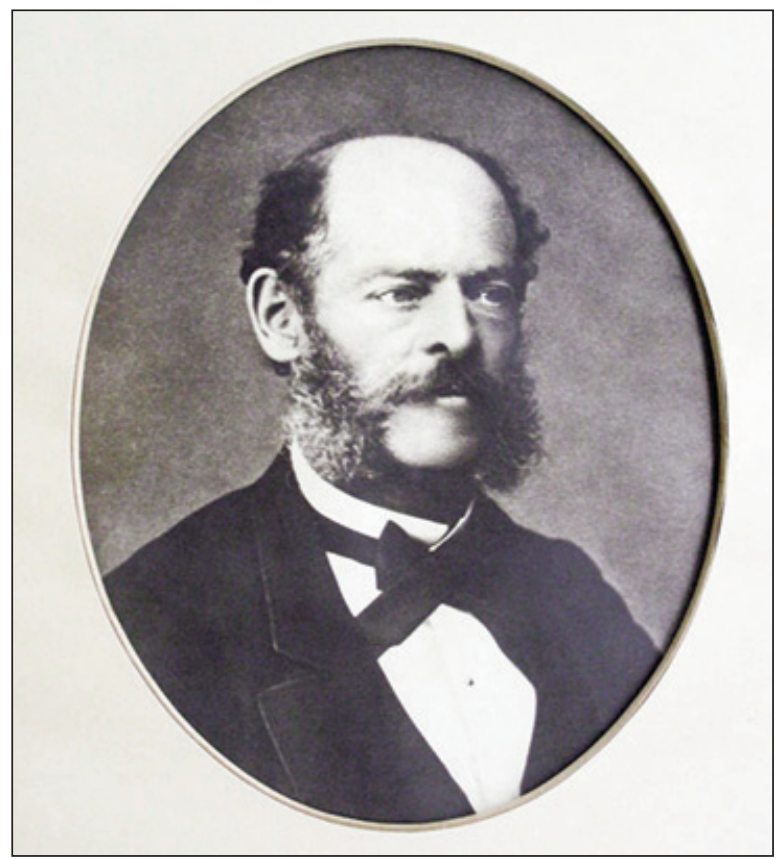

Figura 2. Marcelino Sanz de Sautuola. Museo de Altamira. 
Se casó en 1865 con $\mathrm{M}^{\mathrm{a}}$. Concepción Escalante, la hija del alcalde de Santander entre 1863-66, Cornelio Escalante, con la que tuvo tres hijas, $\mathbf{M}^{\mathrm{a}}$. Juana, $\mathbf{M}^{\mathrm{a}}$. Josefa y en 1870 a $\mathrm{M}^{\mathrm{a}}$. Justina Isabel, la única que llegó a edad adulta (Madariaga, 2004: 34-35).

Por su interés en la arqueología, a los 35 años se incorporó en 1866 a la recién reorganizada Comisión de Monumentos de Santander, de la que llegó a ser vicepresidente (Madariaga, 2004: 32,50) y ese año fue elegido Correspondiente de la Real Academia de la Historia. Poco después, en 1868, uno de sus aparceros, Modesto Cubillas Pérez, localizó la cueva de Altamira al introducirse en el interior su perro de caza (Madariaga, 1976: 20 y 2004: 63). La visita al pabellón de Antropología en la Exposición Universal de París de 1878 le impulsó a iniciar la exploración de las cuevas que conocía en su entorno inmediato, comenzando excavaciones durante varios días en una cueva en Camargo que parece tratarse de la Cueva del Pendo o de San Pantaleón, pues así la identifican Vilanova y de la Rada (1893: 459), donde a los $0.30 \mathrm{~m}$. ya localizó de útiles de sílex y hueso trabajados, huesos y dientes de animales, en particular de caballo y ciervo, patellas y ostras (Sanz de Sautuola, 1880: 3-8, lám. 1). Las prospecciones las continuó en Santillana del Mar, junto al prado de Altamira, en una cueva que había visitado en 1876 (Sanz de Sautuola, 1880: 11-12). Realizó también excavaciones en la cueva de Altamira, localizando en la galería principal, bajo una capa estalagmítica de $1 \mathrm{~cm}$. de grueso, otra de hasta $1 \mathrm{~m}$. de espesor con útiles de hueso y asta trabajados como una aguja y varios punzones, una pizarra perforada a modo de colgante, útiles de sílex, huesos y dientes de animales, numerosas patellas y pedazos de ocre rojo ( $\operatorname{Sanz}$ de Sautuola, 1880: 12-14, 21, lám. 2). Donde concluía esta capa, observó 23 animales pintados en ocre negro y rojo sobre la bóveda de la cueva, que representaban bisontes, un corzo y una cabeza de caballo. Estas últimas pinturas las localizó en la cueva en 1879 por la oscuridad de la sala (Sanz de Sautuola, 1880: 15-16, 23, lám. 3), siendo primero observadas por su hija María Justina con 8 años (Vilanova, 1881a/1997: 114). En la segunda galería sólo localizó en un hueco en el fondo 4 figuras con pinturas negras (Sanz de Sautuola, 1880: 17, lám. 4/1-4). En la tercera sala una figura (Sanz de Sautuola, 1880: 17, lám. 4/5) y a la entrada de la cuarta galería dos figuras más (Sanz de Sautuola, 1880: 17-18, lám. 4/6-7). Otras 5 nuevas figuras con pintura negra las localizó en la quinta galería, de difícil acceso pues exigía entrar de rodillas, siendo la $\mathrm{n}^{\circ} 12$ la primera que identificó en sus visitas a la cueva por estar a 2 pies del suelo y ser trazos negros (Sanz de Sautuola, 1880: 19, 22, lám. 4/8-12). En sus conclusiones señala que figuras de animales similares se localizaban sobre cuernos de reno y colmillos de marfil en la obra del Sir John Lubbock (1865: 303-305), primer barón de Avebury, calificándolas de época Paleolítica (Sanz de Sautuola, 1880: 21 n. 1, 23).
Sanz de Sautuola informó del descubrimiento al Anticuario de la Real Academia de la Historia, Fernández-Guerra, el 8 de agosto, cuando le escribió por primera vez, comunicándolo en sesión académica el 17 de octubre de 1879 (Madariaga, 2004: 65 n. 36, 68). Las pinturas fueron descubiertas antes del 8 de noviembre, pues una carta de Sanz de Sautuola señala que estaba buscando un buen pintor para reproducir "con toda fidelidad y exactitud una porción de animales pintados en la bóveda de una cueva (...) los animales están hechos con toda la perfección" (Madariaga, 1976: 277), eligiendo a Paul Ratier. El empleo en las excavaciones de labradores de varios pueblos contribuyó a divulgar el hallazgo en las localidades próximas y ya en noviembre de 1879 se organizó una visita, sin presencia de Sanz de Sautuola, con personas de los pueblos de Torrelavega, Cerrazo y Villapresente, que fue continuada por otras a lo largo de los primeros meses de 1880 (El Impulsor, 26-9-1880: 4; Madariaga, 1976: 235). Ello probablemente impulsó a Sanz de Sautuola a colocar una puerta de madera en la entrada de la cueva, previa autorización del ayuntamiento, cuya solicitud efectuó en enero de 1880 (Madariaga, 1976: 214-216, 280).

Cabe presumir que Vilanova, al menos desde inicios de 1880 , ya tuvo conocimiento del descubrimiento, pues en caso contrario no se entiende que ya antes de marchar a principios de septiembre de 1880 a visitar la cueva y de publicarse el trabajo de Sanz de Sautuola hablase de "la Cueva de Altamira, por tantos conceptos famosa ya" (Actas de la SEHN, 1-9-1880: 76). Según el mismo indica, recibió una primera carta informándole de los descubrimientos de artefactos en ambas cuevas y Vilanova (1881a/1997: 105) le confirmó su pertenencia al "periodo del reno", recibiendo "á poco tiempo", una segunda carta donde ya le informaba de la presencia también de pinturas rupestres, incluyendo algún dibujo (Vilanova, 1881a/1997: 106). Preparando su divulgación pública, Sanz de Sautuola solicitó al Ayuntamiento de Santillana del Mar el 22 de agosto de 1880 la colocación de una puerta de hierro para su protección (Madariaga, 1976: 214-215).

Antes de la publicación del trabajo Breves apuntes sobre algunos objetos prehistóricos de la provincia de Santander (Sanz de Sautuola, 1880), Vilanova recibió una selección de piezas de la cueva de Altamira y probablemente copia del texto quizás ya impreso, enviado por Sanz de Sautuola. Estos materiales los presentó en junta del 1 de septiembre en la Sociedad Española de Historia Natural, aprobándose una comisión formada por Vilanova y su presidente, Ángel Guirao, para hablar con el Ministro de Fomento, el guipuzcoano Fermín Lasala y Collado, Duque de Mandas, para que "estimule con su eficaz auxilio la exploración de esas cavernas" (Actas de la SEHN, 1-9-1880: 76-77). El Ministro comisionó a Vilanova (1881a/1997: 41) para evaluar las pinturas, a la vez que envió a un alto fun- 
cionario del ministerio, antropólogo y americanista, Miguel Rodríguez-Ferrer para asistir a la visita. El tercer comisionado fue Francisco Giner de los Ríos, que "conoce ya, como casa propia (...) esta provincia, porque la recorre casi anualmente con pies de bronce" (Rodríguez-Ferrer, 1880: 208). El 8 de septiembre los tres coincidieron en la cueva, señalando RodríguezFerrer (1880: 206-207) que ese día Vilanova localizó el cráneo completo de un oso de las cavernas o Ursus spelaeus "en lo más profundo de la galería larga" (Vilanova, 1881a/1997: 122). También identificó conchas de Littorina littorea, dientes de caballo, ciervo, uro y jabalí, con dudas sobre el bisonte pues "sólo las vértebras dorsales y lumbares ofrecen el carácter de tener más largas las apófisis espinosas" (Vilanova, 1881a/1997: 117 y 121). A su juicio, la clave en la antigüedad de la cueva era "la falta absoluta de restos de cerámica” (Vilanova, 1881a/1997: 122). En la descripción de Rodríguez-Ferrer también se aportan datos complementarios sobre las pinturas, como la presencia de un jabalí corriendo o de un caballo casi completo más desvanecido, rechazando la posible falsedad de las pinturas porque "se han utilizado los accidentes de la misma [roca] haciendo relieve de las protuberancias de su superficie" (Rodríguez-Ferrer, 1880: 207). La visita de Vilanova (1881a/1997: 116) se alargó una semana, pues dos días antes de la conferencia impartida en el Instituto Provincial, el 10 de septiembre, visitó la cueva del Pendo de Camargo, donde identificó mandíbulas de caballo, uro, ciervo y jabalí, o huesos con señales de haber sido quemados, destacando el mayor porcentaje de útiles líticos de cuarcita o cristal de roca (Vilanova, 1881a/1997: 125).

Durante su estancia, Vilanova (1881a) debía impartir dos conferencias en Santander, una de prehistoria general en el casino de Santander el 11 de septiembre y otra que tuvo mayor repercusión en el Instituto Provincial, a la que asistió el Gobernador Civil y se centraba en Altamira, el 12 de septiembre. Allí presentaron parte de los objetos recuperados en el Pendo de Camargo y Altamira y se señala que ya estaba impreso el texto de Sanz de Sautuola (Boletín de Comercio, 149-1880: 1-2; Madariaga, 1976: 223-225).

En Santander seguramente recogió ejemplares de la publicación para entregarlos en el IX Congreso Internacional de Antropología y Arqueología Prehistórica que se celebraba en Lisboa la semana siguiente, entre el 20 y 29 de septiembre. Simultáneamente al congreso, fue puesta a la venta la publicación el 20 de septiembre de 1880 (El Aviso, 219-1880: 2) y dada a conocimiento público en la portada de El Impulsor (26-9-1880: 1-4) de Torrelavega. Puesto que Vilanova realizó una invitación a visitar la cueva en Santander a los congresistas de Lisboa que "debían volver de Lisboa a Francia, por Bayona" (El Eco de la Montaña, 30-12-1880; Madariaga, 1976: 49), cabe suponer que la fecha de publicación y cono- cimiento público del hallazgo se retrasó conscientemente para darle mayor repercusión pública y conseguir de paso el reconocimiento científico por los asistentes al congreso. Sin embargo, quizás en Lisboa ya surgieron las primeras reticencias de algunos prehistoriadores franceses, pues aunque "se dirigió una atenta invitación á los congresistas que quisieran hacer el viaje hasta Santander, invitación que no pudo aceptarse por razones que debo reservar". A ello se sumó que otra parte de los congresistas pensaban continuar su viaje en dirección "hacia Andalucía y Valencia" (Vilanova, 1884b: 314-315).

El problema estalló a partir de la publicación de tres opiniones negativas. Por una parte, en la propia Santander, va a ser Ángel de los Ríos y Ríos, miembro de la Comisión Provincial de Monumentos, Correspondiente de la Real Academia de la Historia y Cronista de la provincia de Santander, quien sostendrá la cronología tardía de las pinturas en distintos artículos periodísticos desde el 30 de septiembre, al hacer una reseña del libro de Sanz de Sautuola (El Eco de la Montaña, 30-9-1880), que fueron contestadas por Sanz de Sautuola, ofreciéndose a llevarlo a visitar también la Cueva del Pendo de Camargo (El Eco de la Montaña, 4-11-1880; Madariaga, 1976: 144). El 20 de noviembre, Ángel de los Ríos visitó la Cueva de Altamira acompañado por Eduardo de la Pedraja, inclinándose por una cronología romana, cuando aún existían uros en la Selva Negra descritos por Julio César (El Eco de la Montaña, 2-1-1881; Madariaga, 1976: $159,163)$, concluyendo que la cronología de las pinturas sería entre Sertorio y Tiberio (El Eco de la Montaña, 13-1-1881; Madariaga, 1976: 166), esto es, entre inicios del siglo I a.C., pues Sertorio murió el 72 a.C., y mediados del I d.C., ya que Tiberio falleció el 37 d.C.

En segundo lugar, surgieron reticencias en Madrid, pues probablemente Giner de los Ríos no se quedó convencido en su visita, y envió una comisión de dos geógrafos, miembros de la Institución Libre de Enseñanza, Francisco Quiroga y Rafael Torres Campos, que fueron acompañados por Eduardo Pérez del Molino Rosillo, farmacéutico de Torrelavega. Los autores, aunque reconocen que hay "una cabeza de caballo o ciervo de gran parecido con las del bastón de mando hallado por MM. Lartet y Christy en la Magdalena", señalan que en las técnicas del pintor de Altamira se encuentran "perspectiva lineal, perspectiva aérea, color desleído en agua o grasa, pincel. Trabajo cuesta creer que los habitantes de las cavernas en la Edad del Reno adelantaran bastante para hacer dichas pinturas". Por ello acabaron defendiendo que fueron realizadas "Cuando después de la segunda guerra cantábrica las legiones romanas ocuparon el territorio de los vencidos, y los expulsaron de los sitios altos (...) pudo estar habitada la cueva de Altamira por soldados romanos que entretuvieran sus ocios pintando ciervos, 
caballos y bisontes" (Quiroga y Torres Campos, 1880: 162-163). Otro miembro de la Institución Libre de Enseñanza, Salvador Calderón y Arana (1884: 12), también propuso que eran posteriores a la llegada de las "civilizaciones orientales" a España, lo que fue rechazado por Vilanova aconsejándole visitar primero la cueva, y fue aprovechado por Quiroga para reafirmarse en su opinión negativa, señalando que había vuelto de nuevo a la cueva con el entomólogo Ignacio Bolivar y Urrutia, en el verano de 1883 , por sus conocimientos en el dibujo de animales (Actas de la SEHN 1884: 14).

El tercer frente y más problemático fue el internacional. El descubrimiento fue bien acogido al menos por Henri Martín, quien escribió a Sanz de Sautuola, disculpándose por carta el 5 de octubre de 1880 de no poder visitar la cueva después del congreso de Lisboa. "Parece muy poco probable que gentes de la Edad Media o Moderna hayan inventado dichas pinturas. ¿Quién les hubiera sugerido la idea, no conociendo el bisonte de Europa, tantos siglos hace desaparecido de España y Francia? (...) Por el contrario, hay en los dibujos ciertas analogías con los trazados sobre piedras o huesos (...) por los hombres de la última edad de las cavernas" (El Eco de la Montaña, 31-10-1880: 1; Madariaga, 1976: 48). Es probable que esta sea la carta leída por Vilanova en la Sociedad Española de Historia Natural en enero de 1881 (Actas de la SEHN, 5-11881: 6). Por su parte, Emile Cartailhac, director de la revista Matériaux pour l'histoire primitive et naturelle de l'homme desde 1869, le escribió el 5 de diciembre de 1880 desde Toulouse y señalaba la importancia del descubrimiento. "No creo que se halla hecho en España otro descubrimiento más importante que el de Vd., bajo el punto de vista de la arqueología prehistórica", indicándole que pensaba hablar con Louis Lartet (El Eco de la Montaña, 30-12-1880; Madariaga, 1976: 49-51), quizás para realizar una vista a la cueva. Al final la persona elegida fue el ingeniero de ferrocarriles Édouard Harlé, residente en Burdeos, que llegó a Santander a finales de febrero, durante el Carnaval, siendo acompañado por Sanz de Sautuola y Pérez del Molino a la cueva. Allí recogió ejemplos de los artefactos prehistóricos y realizó dibujos de las pinturas, considerando después de su estancia que "la importancia de las pinturas que encierra esta cueva es extraordinaria" (Boletín del Comercio, 3-3-1881: 2; Madariaga, 1976: 256-257). La visita se repitió durante la Semana Santa durante "dos días seguidos", "con el objeto de aclarar algunas dudas que han surgido de su informe verbal", destacando haber localizado un detalle que reforzaba la antigüedad de las pinturas, "en varios dibujos o pinturas se hallan trozos más o menos cubiertos por una capa estalactítica, compuesta de cristales casi microscópicos" (Boletín del Comercio, 24-41881: 2; Madariaga, 1976: 257-258). Sin embargo, el informe final de Harlé (1881: 282) indicaba que las pinturas de la sala principal eran recientes y "las incrustaciones [estalactíticas] son demasiado pequeñas para concluir una gran antigüedad", fechando en época contemporánea la falsificación, entre 1875-79, argumento irritante para Vilanova y Rada (1893: 458) que le respondía "¡risum theneatis amici!". Otro tanto sucedió con Cartailhac en 1881, que se manifestó públicamente en contra en el congreso de la Association française pour l'avancement des sciences de Argel. Allí Vilanova volvió a sacar el tema de la contemporaneidad de las pinturas rupestres con los "restos de cocina que se conservan en el suelo". Sin embargo, presumiendo que saldría este tema, Cartailhac había remitido una carta donde "desmiente que dichas pinturas sean prehistóricas", siendo respondido por Vilanova que emitía su opinión "sobre unas pinturas que no ha visto sino en reproducciones", lo que "revestía un carácter de imperdonable ligereza" (Actas de la SEHN, 1-6-1881: 32; Vilanova, 1881b: 32 y 1884b: 381). También Vilanova descalificó el informe de Harlé en la Sociedad Española de Historia Natural considerándola "una memorieta redactada por un ingeniero francés, que tiene poco conocimiento sobre el asunto" (Actas de la SEHN, 7-6-1882: 57).

Frente a la postura inicial más receptiva de Harlé y Cartailhac, fue Mortillet quien mantuvo una postura de rechazo frontal contra la autenticidad de las pinturas, señalándole en una carta a Cartailhac de 19 de mayo de 1881 que "Con sólo mirar las copias de los dibujos que me envía en sus cartas, puedo ver que se trata de una farsa; de una simple caricatura. Han sido hechas y mostradas al mundo para que todos se rían de los crédulos paleontólogos y prehistoriadores" (Madariaga, 1976: 34). La postura final adoptada por Mortillet (1883) en Le préhistorique. Antiquité de l'homme y después por Cartailhac (1886: 39) en Les âges prehistoriques de l'Espagne et du Portugal, fue mencionar las excavaciones dentro de la cueva, resaltando la ausencia de huesos de bisontes, e ignorar la existencia de las pinturas, descalificando implícitamente las opiniones de Sanz de Sautuola y de Vilanova, quien le contestaba señalando que "Con tanto desdén trata Cartailhac lo de la cueva de Santillana, que ni siquiera señala la existencia de las pinturas en la obra" (Vilanova y de la Rada, 1893: 458 n. 1).

Vilanova prosiguió con su defensa de la autenticidad de la Cueva de Altamira en los foros internacionales, en el $11^{\circ}$ Congreso de l'Association française pour l'avancement des sciences (La Rochelle, 1882) (Vilanova, 1883) y en el $15^{\circ}$ Congreso celebrado en Nancy (Vilanova, 1886a). Por otra parte, en España continuaban surgiendo voces contrarias a su cronología paleolítica en la Sociedad Española de Historia Natural, como la del santanderino de Torrelavega, Eugenio Lemus y Olmo, grabador y director de la Calcografía Nacional, que visitó la Cueva de Altamira en el verano de 1886, calificándolas de "escuela 
moderna (Actas de la SEHN, 3-11-1886: 81). Esta intervención motivó una defensa más detenida de las pinturas por Vilanova (1886b), si bien Lemus y Bolivar se ratificaron en sus opiniones previas, señalando Bolivar que "la perfección y proporciones de las figuras demuestran el dominio de las grandes líneas y el conocimiento de la perspectiva, cosas ambas que no pueden suponerse en un hombre salvaje". Otro tanto señalaba el biólogo Eduardo Reyes y Prósper, que había sido becario de la Real Academia de Pintura, Escultura y Grabado de San Carlos de Valencia, por la "seguridad y soltura en el trazado, una intención en el claro oscuro, que no se encuentra ni en los dibujos de edades prehistóricas, ni en los de las históricas, antigua y media", sugiriendo por defecto una cronología moderna o contemporánea (Actas de la SEHN, 1-121886: 95-97). Frente a estos argumentos, Vilanova les recordaba que "De haberlas pintado como algunos pretenden, en tiempos modernos, lo natural parece que el artista se hubiera valido de colores preparados para el fresco, temple ú oleo" (Vilanova y de la Rada, 1893: 457). En este contexto adverso, Sanz de Sautuola falleció el 2 de junio de 1888, sin que se aceptara mayoritariamente la autenticidad de las pinturas.

\section{JuAn de la Rada y Delgado y El DESCubrimien- TO DEL ARTE IBÉRICO}

Si Juan Vilanova fue el geólogo y prehistoriador español más importante de la Restauración, desde un punto de vista institucional el arqueólogo más importante fue Juan de la Rada, y como tales ambos fueron elegidos para redactar las secciones de Prehistoria y Protohistoria en la Historia General de España de la Real Academia de la Historia (Vilanova y de la Rada, 1893). La mejor etapa profesional de Rada cabe situarla entre 1870-85, aunque su trayectoria científica se vio afectada desde que accedió a la dirección de la Escuela Superior de Diplomática en 1876, que debió absorber buena parte de su tiempo, la cual simultaneó desde 1891 con la dirección del Museo Arqueológico Nacional. Hacia 1885 ambos fueron superados por una nueva generación de investigadores europeos como Siret, Bonsor o Paris, que cubrieron distintos aspectos de la prehistoria española por la ausencia de especialización en Catalina García, la elevada edad de Fernández-Guerra o la dedicación a la política y al derecho de Riaño.

Juan de Dios de la Rada y Delgado nació en Almería el 28 de septiembre de 1825, pero su fecha de nacimiento ya genera un problema serio pues existen dos partidas de nacimiento con su nombre, Juan de Dios Nicolás Fabio Miguel de la Rada y Delgado, del 28 de septiembre de 1825 y otra el 8 de abril de 1829 . No es un problema banal porque cuando fue obligado a jubilarse era el arqueólogo más importante de España. La sugerencia de Papí (2004: 253-254 n. 7-8) de que debió nacer primero otro hermano que falleció y se le dio de nuevo su nombre podría ser la más lógica, sugiriendo por ello la fecha de 1829, pues al fin y al cabo repite el nombre del padre al ser el primer hijo, pero en su necrológica se indica 1827 (Sentenach, 1901: 640) y más en concreto el 13 de agosto de 1827 (Ruiz Cabriada, 1958: 807; Vargas-Zúñiga, 1979: 30; Peiró y Pasamar, 1996: 70 n. 135; Pasamar y Peiró, 2002: 509), que no coincide tampoco ni en el año, ni en el mes, ni incluso en el día con ambas partidas de nacimiento (fig. 3).

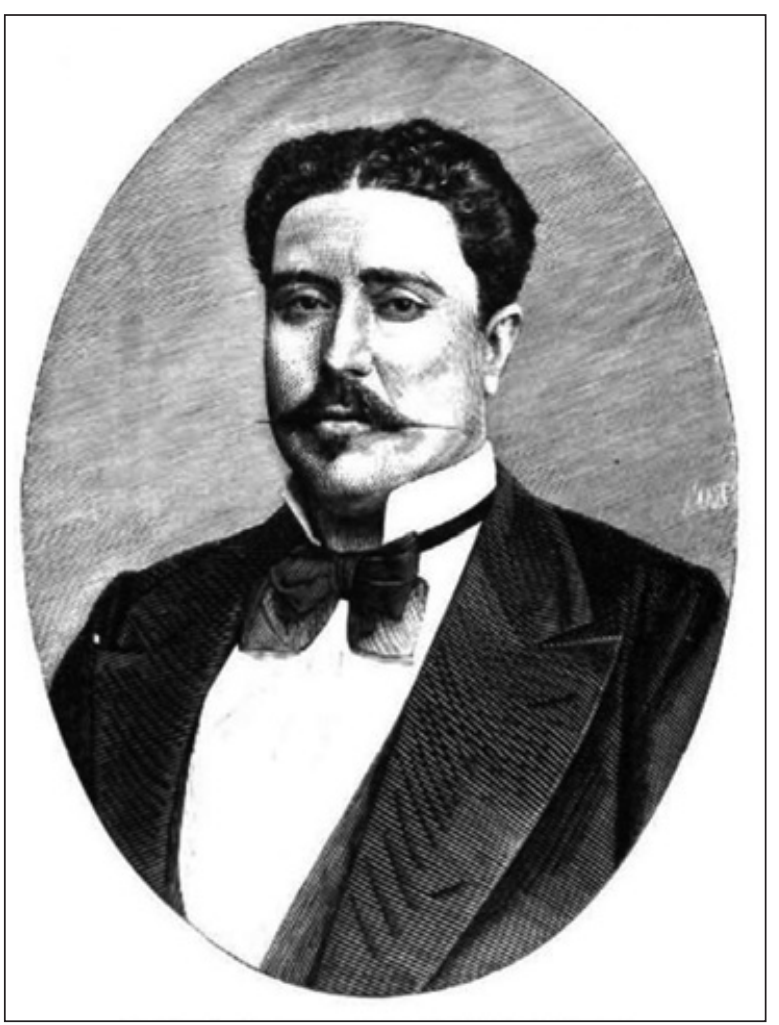

Figura 3. Juan de Dios de la Rada y Delgado.

Su padre, Juan de Dios de la Rada y Henares, profesor de Anatomía de la Facultad de Medicina de la Universidad de Granada, separado de su plaza en 1823 y objeto de persecución política por ser liberal, ganó la plaza de médico del Hospital del Cabildo Catedralicio de Almería el 12 de junio de 1825, al fallecer su anterior titular. Pudo reincorporarse a la universidad al menos desde noviembre de 1833 (Ramallo, 1976: 29-30), ya proclamada Isabel II, como catedrático de Ciencias Físico-Matemáticas hasta su jubilación en 1848 .

Rada entró a trabajar en la Universidad de Granada como Regente agregado en Ciencias Filosóficas (1847-49), cursó el primer año de Medicina (1849-50) al morir su padre, pero al año siguiente entró a trabajar como Oficial primero de la Secretaría de la Universidad (1850-53), a la vez que se doctoró en Derecho (1852) con Reflexiones sobre 
las pruebas judiciales en materia criminal y fue profesor gratuito en la cátedra de Notariado en el curso 1852-53. Sin embargo, en el curso siguiente se trasladó a Madrid, incorporándose en noviembre de 1853 a la secretaría de la Universidad de Madrid con la misma categoría de Oficial primero hasta 1856 (Pasamar y Peiró, 2002: 509; Papí, 2004: 254). Simultáneamente, probaba como literato con poesías, dramas de teatro y novela histórica.

Fue propuesto como Correspondiente en la Real Academia de la Historia el 26 de enero de 1854 y admitido el 28 de abril de 1854, avalado por el liberal Antonio Delgado entre otros (Vargas-Zúñiga, 1979: 30), seguramente vinculado a la presentación de un estudio sobre la ubicación de la antigua Iliberri, entregado el día que fue admitido (Almagro Gorbea, 1999: 147), que publicó años después (de la Rada, 1863). Es posible que en esos años asistiera a los cursos impartidos por Manuel de Assas en el Ateneo de Madrid sobre Arqueología Española (1854-56 y 1858-60) (Roca, 1898: 14-16) y tuvieran influencia en su formación.

Una cuestión importante es su entrada como catedrático de Arqueología y Numismática, en comisión desde el 18 de noviembre de 1856, en la Escuela de Superior de Diplomática, con 29 años, donde fue catedrático en propiedad desde el 10 de julio de 1858 hasta 1863 (Pasamar y Peiró, 2002: 509), que parece que fue debido al apoyo del Ministro de Gracia y Justicia hasta el 14 de julio de 1856, catedrático de Disciplina Eclesiástica general y particular de España y miembro del Partido Progresista, el soriano Joaquín Aguirre de la Peña, que colocó en la Escuela a sus dos ayudantes en la Facultad que le sustituyeron en las clases durante los cursos 1854-57. El abogado almeriense de la Rada en $4^{\circ}$ curso era sustituto en la cátedra de Disciplina Eclesiástica, y el abogado cordobés Santos de Isasa y Valseca en $6^{\circ}$ y $7^{\circ}$ curso, el cual accedió el 30 de septiembre de 1857 a la cátedra de Historia de España de los tiempos medios, con 25 años (Sentenach, 1901: 640; Ramírez, 1977: 219; Peiró y Pasamar, 1996: 65 n. 121, 69 n. 154; Pasamar y Peiró, 2002: 331; Papí, 2004: 254). El gobierno hasta julio de 1856 había sido dirigido por Espartero como Presidente, pero ya figuraba como Ministro de la Guerra, Leopoldo O’Donnell, quien asumió la presidencia con la Unión Liberal desde el 14 de julio de 1856 hasta el 12 de octubre y debía conocer bien a Aguirre. Sin embargo, las tomas de posesión de Rada y de Isasa fueron ya con gobierno de Narváez y siendo Ministro de Fomento, Claudio Moyano Samaniego. En segundo lugar, con este ministro entró Aureliano Fernández-Guerra, que había sido cesado durante el Bienio Liberal entre 1854-56, y fue nombrado Secretario del Consejo de Instrucción Pública el 29 de octubre de 1856 por Moyano. Como había amistad entre los padres de ambos por sus aficiones literarias (de la Rada, 1894b: 158), hace pensar que para que el nombramiento fuese efectivo, y más con un gobierno del signo político opuesto, Fernández-Guerra tuvo un papel importante.

Entre 1863-67 pasó a detentar la cátedra de Numismática Antigua y de la Edad Media y finalmente de Numismática y Epigrafía desde el 21 de noviembre de 1868 hasta la supresión de la escuela el 20 de julio y su jubilación el 4 de agosto de 1900. Su puesto de director de la Escuela Superior de Diplomática entre el 5 de abril de 1876 y el 20 de julio de 1900 (Peiró y Pasamar, 1996: 45), fue el cargo más importante que desempeñó, durante 24 años, a lo largo de toda la Restauración.

En los años sesenta su principal valedor fue Amador de los Ríos, con el que escribió una Historia de la Villa y Corte de Madrid (de los Ríos, de la Rada y Rosell, 1860-64). Eso favoreció que le incorporase desde el 6 de abril de 1868 al Museo Arqueológico Nacional, a los 2 meses de acceder Amador de los Ríos, junto con Manuel de Assas, que demuestran el buen criterio de Amador de los Ríos. Este museo lo dirigió de la Rada cuando le tocó por antigüedad en el escalafón, entre el 19 de febrero de 1891 hasta su jubilación el 4 de agosto de 1900, encargándose del traslado de las colecciones a su actual sede entre 1893-95, y permaneciendo brevemente como director del Museo de Reproducciones Artísticas hasta su muerte el 3 de junio de 1901 (Marcos Pous, 1993: 61).

Debido al cese de Amador de los Ríos en 1868, con sólo 9 meses en el cargo, fue Rada quien estableció el sistema de catalogación y presentación de piezas en el Museo Arqueológico Nacional al ser Jefe de Tercer Grado desde 1869, y puesto que su sustituto fue el poeta Ventura Ruiz Aguilera hasta 1872, señala Marcos Pous (1993: 56) que Rada "parecía dirigir el Museo". Tampoco debe olvidarse que en este periodo el museo se inauguró al público en julio de 1871. La situación no debió cambiar mucho durante el periodo de dirección del dramaturgo Antonio García Gutiérrez, entre 1872-1881, etapa en que ascendió en 1873 a Jefe de Segundo Grado (Papí, 2004: 255) y se publicó la Noticia histórica-descriptiva del Museo Arqueológico Nacional, publicada siendo Director del mismo el Excmo. Sr. D. Antonio García Gutiérrez (de la Rada, 1876c), pues como señala Sentenach (1901: 643) "es debido en casi su totalidad a D. Juan de Dios" y según Mélida (1903b: 140) fue "escrita en su mayor parte por el Sr. Rada y publicada para enviarla a la Exposición [Internacional] de Filadelfia" en 1876, en la exposición que conmemoraba el Primer Centenario de la Independencia de los Estados Unidos donde fue premiada. El 14 de diciembre de 1882 obtuvo el título de Archivero y Bibliotecario (Ruiz Cabriada, 1958: 807). Desde enero de 1884 fue ascendido a Jefe de Primer Grado (Papí, 2004: 255) y entró Mélida a sustituirlo como responsable de la Sección Primera de Protohistoria y Edad Antigua. 
Quizás su labor más brillante, aparte de la dirección de la Escuela Superior de Diplomática y del Museo Arqueológico Nacional, fue como editor. Tenía una notable experiencia dirigiendo la Revista Universitaria (1856-61) (Pasamar y Peiró, 2002: 509), que continuó con numerosas colaboraciones en El Museo Universal entre 1858-68, a veces con el pseudónimo de AdarRada, cuando finalmente creó la lujosa revista Museo Español de Antigüedades (1872-80), que representó institucionalmente al Museo Arqueológico Nacional. Publicada a gran formato, fue financiada por el editor José Gil de Dorregaray, y sirvió para dar prestigio a la institución, redactando además 41 artículos en ella. Al dejarse de publicar, por el fallecimiento de Gil de Dorregaray, junto a Fidel Fita, fue el responsable del Boletín de la Real Academia de la Historia desde 1883 a 1901, la revista más importante para la Arqueología del último cuarto del siglo XIX junto con los Anales de la Sociedad Española de Historia Natural.

Otros proyectos editoriales fueron la Revista de Bellas Artes, histórico-arqueológica (1867-68), primer proyecto conjunto con Francisco $\mathrm{M}^{\mathrm{a}}$. Tubino, que retomaron con La Academia. Semanario Ilustrado Universal. Artes, Ciencias, Literatura, Actividades (1877-79), patrocinado por Gil de Dorregaray, que finalizó también al morir el editor.

Quizás por esa razón fue una de las tres personas en las que Cánovas delegó después de una reunión en su casa el 21 de julio de 1886, la publicación de una Historia General de España (Peiró y Pasamar, 1996: 80 n. 141). Los elegidos fueron Gayangos que había dirigido el Memorial Histórico Español; Menéndez y Pelayo, quien a partir de 1900 fue el director de la Revista de Archivos, Bibliotecas y Museos y de la Rada. Sin embargo, no viene mal recordar que ni Gayangos, ni Menéndez y Pelayo redactaron la parte que les correspondía en la obra.

Parte de sus libros se centraron en catálogos de las colecciones en las instituciones que trabajó, generalmente encargándoselos a otros investigadores. Primero el Catálogo del Museo Arqueológico Nacional. Primera Sección [Protohistoria y Edad Antigua] (de la Rada, 1882), reescrito por Mélida (Almela Boix, 1991b: 131), quien indica que Rada "dirigió la publicación de este libro" (Mélida, 1903b: 147) y más en concreto la "Introducción é inspección del tomo" (Sentenach, 1901: 643). Después el Catálogo de monedas arábigas españolas que se conservan el Museo Arqueológico Nacional (de la Rada, 1892), realizado por Vives y revisado por Codera (Alfaro, 1993: 151), y buena parte del Inventario de las antigüedades y objetos de arte que posee la Real Academia de la Historia (Almagro Gorbea, 1999: 147), publicado una vez muerto por Catalina García (1903), donde no se incluyó ni la numismática ni la epigrafía. Su docencia en numismática, de la que no era especialista, también fue recogida por uno de sus alumnos, Eduardo González
Hurtebise (1895), en Apuntes de Numismática tomados de las explicaciones del catedrático de la asignatura D. Juan de Dios de la Rada y Delgado.

$\mathrm{Su}$ interés por la Arqueología del Próximo Oriente se refleja en los lujosos 3 tomos del Viaje a Oriente de la fragata de guerra 'Arapiles' y la Comisión científica que llevó a su bordo (de la Rada, 1876, 1878 y 1882). Poco después de su regreso de la expedición del viaje en la fragata Arapiles, de la Rada fue propuesto el 16 de febrero de 1872 como Numerario en la Real Academia de la Historia, avalado por FernándezGuerra, Madrazo o Fernández y González, siendo elegido el 8 de marzo (Vargas-Zúñiga, 1979: 30).

Trató de preparar un discurso de ingreso adecuado, que le llevó 3 años su redacción, la primera monografía sobre el arte ibérico, Antigüedades del Cerro de los Santos en término de Montealegre (de la Rada, 1875a y b), pues "Hallé en el Museo las primeras estatuas y objetos que á él vinieron, al regresar de mi viaje á Oriente" (de la Rada, 1875b: 250). Al año siguiente publicó un artículo donde daba noticia de las nuevas adquisiciones de esculturas a Amat para el museo en 1875 , que por incluir el principal grupo de falsificaciones egiptizantes le hicieron reforzarse en la influencia egipcia y la presencia de inscripciones jeroglíficas (de la Rada, 1876b), un tema que le atraía desde muy joven (de la Rada, 1858 y 1860a).

El Cerro de los Santos quedó accesible cuando se taló el bosque que lo cubría en 1830 (Savirón, 1875: 128), lo que propició que hallazgos aislados de esculturas sirvieran para otorgarle el nombre de Cerro de los Santos (Lasalde, 1871: 67; Savirón, 1875: 127). Comenzó a ser explorado más intensivamente en 1859 por el valenciano José Biosca Mejía (1873) y en 1860 por un "lapidario y escultor francés" residente en Yecla (Fernández de Avilés, 1948-49: 59), divulgándose su conocimiento, y en enero de 1860 fue explorado por el artista Juan de Dios Aguado y Alarcón (1875-76). Durante sus excavaciones localizó 18 fragmentos de esculturas, enviando el 28 de junio una comunicación a la Real Academia de Bellas Artes de San Fernando con dibujos de 7 esculturas, la cual remitió el informe el 29 de octubre a la Real Academia de la Historia y donde el 3 de noviembre se agradeció su envío (Fernández de Avilés, 1948-49: 60-61 n. 13; Maier, 1999c: 26), pero ninguna de las dos academias parecen haberse interesado en detalle por los hallazgos. De esta colección, 2 cabezas acabaron en el Museo del Louvre y otras 2 en los museos de Murcia y Yecla (Mélida, 1903a: 474-475; Fernández de Avilés, 1948-49: 6061). El escrito de Aguado fue utilizado por Amador de los Ríos (1863) para plantear que se trataban de esculturas visigodas de mártires procedentes de un martyrium, hipótesis que siguió defendiendo 25 años después su hijo, Rodrigo Amador de los Ríos (1889: 762771), afirmando la presencia "durante la dominación visigoda [de] un Martyrium, y que todas aquellas estatuas (...) pertenecen á la época visigoda”. 
Entre 1860-70 debieron producirse nuevas rebuscas en el cerro, formándose pequeñas colecciones como la del cura de la Concepción de Yecla, José Palao Marco, de 5 cabezas y 3 fragmentos, fallecido en 1890 , que fueron vendidos a Paris para el Museo del Louvre (Fernández de Avilés, 1948-49: 63). En 1870 se hicieron excavaciones en la base del cerro y se localizó la estatua femenina completa de $1.50 \mathrm{~m}$. de altura que fue la primera publicada por Savirón (1873: 478-479 lám.), la cual en 1871 no pudo ser localizada para adquirirla, aunque ya entonces "tuvimos ocasión de admirarla en fotografía” (Savirón, 1875: 194).

Hacia noviembre de 1870 se incorporó a hacer excavaciones el relojero y artista de Yecla, Vicente Juan y Amat, avisado por el notario de Yecla, José Martínez Yuste, que también le consiguió autorización para hacer excavaciones de Juan Antonio Soriano, administrador del Conde de Montealegre y del Marqués de Valparaíso, Francisco de Paula de Bernúy Osorio de Moscoso y Valda, propietario del cerro. Amat se dedicaba a "componer relojes, recoger monedas antiguas y comprar objetos viejos" (Lasalde, 188081 ), indicativo que ya practicaba al comercio de antigüedades. Una vez finalizó la excavación mostró al profesor de los padres Esculapios de Yecla, Carlos Lasalde, algunos de sus resultados y le informó que había sacado "dos ó tres carros de estatuas o pedazos", aunque "apenas había arañado la tierra en un pequeño espacio", quien ponderó tanto la importancia de los hallazgos, quedando Amat "entusiasmado al oirme decir que parecían egipcias" (Lasalde, 1880-81), hasta el punto que el administrador le retiró el permiso. Inmediatamente, inició nuevas excavaciones el padre Lasalde con uno de los hijos del administrador, José María Soriano -guarda mayor del término de Montealegre-, otro guarda denominado el Pelaillas y Juan Bañón -jardinero del Ayuntamiento de Yecla-, entre diciembre de 1870 y enero de 1871, publicando sus resultados inmediatamente en febrero de 1871 (Lasalde y Sáez, 1872; Fernández de Avilés, 1948-49: 64-66; López Azorín y Ruiz Molina, 2000: 39). No es bien valorada la excavación de Lasalde por Savirón (1875: 162) que habla de "las muchas excavaciones practicadas (...) aún sin órden, ni concierto rigurosos", si bien sólo señala dos cortes, uno junto a la estructura rectangular que denomina "recinto principal", excavando "a un lado", y otro corte "Entre el recinto y la cañada” (Lasalde, 1871: 67).

El 13 de mayo de 1872, la Real Academia de la Historia agradeció el envío de la memoria de las excavaciones y se trató la autorización a la continuación de las excavaciones por los padres Escolapios que fue concedida (Mora Rodríguez et alii, 2001: 161), lo que sugiere que quizás Lasalde retomó en 1872 los trabajos de campo después de la campaña de Savirón en 1871, y podrían explicar mejor el comentario de Savirón (1875: 162) sobre "las muchas excavaciones practicadas".
Mucho más rápido reaccionó el Museo Arqueológico Nacional donde ya el 26 de febrero de 1871 solicitaban de la Rada, Bermúdez de Sotomayor, Malibrán y Sala la urgencia de enviar una comisión del museo a visitar el yacimiento, la cual el 28 de febrero el director Ruiz Aguilera trasladaba al Ministro de Fomento, y el 20 de marzo se autorizaba a Savirón, Malibrán y Rodríguez Villa. La marcha de Rada al viaje del Arapiles el 7 de julio, la inauguración del museo por Amadeo I el 9 de julio y el retraso en la recepción de los fondos hasta el 9 de septiembre, relentizaron la partida de la comisión que marchó entre el 13 y el 27 de septiembre, con la baja de Rodríguez Villa por enfermedad. Allí adquirieron el 24 de septiembre en Yecla, 40 esculturas o fragmentos en 630 pesetas o 2.500 reales y no pudieron excavar porque la autorización del propietario llegó el 21 de septiembre, poco antes de regresar, pues sólo estaban autorizados a permanecer fuera durante un máximo de 15 días (Savirón, 1875: 126, 231-232; Mélida, 1903a: 470-471 y 1905b: 32 n. 4).

Ya en esta serie de 40 esculturas o fragmentos había varias falsas, "el Argos, el Fénix, el hipocampo, el rinoceronte, el Cervero (...) la estatua con la flor de loto, la del personaje bendiciendo y una de las sentadas" (Mélida, 1905: 31). Incluso sobre algunas de ellas el padre Sáez del Caño (1871: 371) avisaba que "el ave fénix, un cuadrante" y otras "no vaya a suponerse que indistintamente ha sido extraído todo esto de las excavaciones". Entre esta primera serie de esculturas del Cerro de los Santos sólo entraron un grupo de 3 claras falsificaciones egiptizantes como la Esfinge, el Obelisco o el Cinocéfalo (Pérez-Accino, 2001: 255, 257 fig. 1), pero precisamente el arte egipcio era lo peor que el propio Rada había podido conocer directamente durante la expedición de la fragata Arapiles en 1871, al sólo haber hecho escala en Alejandría ante la falta de recursos.

Paulino Savirón y Estevan fue autorizado a realizar las excavaciones en el Cerro de los Santos por Real Orden de 3 de octubre, para lo cual partió durante un mes, entre el 25 de octubre y el 26 de noviembre de 1871. Una vez llegó, le compró a Amat, apenas tres días después, el 28 de octubre, por 1.100 pesetas, 4 estatuas de piedra, 14 cabezas, varios fragmentos de otras y un toro de piedra, mientras dispuso de 1.400 pesetas para la excavación y otras adquisiciones (Mélida, 1903a: 471 y 1905b: 32 n. 4). De esta serie, las cuatro estatuas de mujer eran auténticas, pero la más que le impresionó era la falsa, una mujer ofreciendo una copa de fuego y los símbolos del sol y la luna, la cual se la regaló Amat "a una sola indicación de los comisionados (...) prueba de su patriotismo" (Savirón, 1875: 233-234; Mélida, 1905b: 22-23, 32). En compensación le compraron el 3 de enero de 1872 dos nuevas esculturas originales por valor de 500 pesetas (Mélida, 1905b: 34 n. 1, 35). 
En la excavación de Savirón se localizaron restos escultóricos por debajo de $1.50 \mathrm{~m}$. de profundidad, e inclusive a nivel de la roca madre donde se hallaron "algunos fragmentos de estatuas, manos y pedazos de cabezas" (Savirón, 1875: 163), destacando dos estatuas fragmentadas "bajo la escalinata del templo" (Savirón, 1875: 229-230, lám. 4/13-14).

Los dos trabajos de Lasalde (1871; Lasalde y Sáez, 1872) atrajeron la atención de otros investigadores como Riaño (1872: 23) que consideró estas estatuas de los siglos III o IV d.C., e hizo desplazarse a Madrid en las navidades de 1872 a uno de los conservadores del British Museum para estudiar directamente estas estatuas (Fernández de Avilés, 1948-49: 59 n. 6), lo que probablemente debió acelerar las compras del Museo Arqueológico Nacional. La primera opinión favorable la dio Layard después de verlas en el museo, lo que motivó que "dos conservadores del Museo Británico (...) uno primero y otro después, han vendido a Madrid (...) sin la más pequeña vacilación ni duda", según le indicaba Fernández-Guerra a Hübner (Fernández-Guerra, 28-10-1875 en Miranda et alii, 2011: 171 carta $^{\circ}$ 143).

Ya desde septiembre de 1872, Rada estuvo barajando el estudio de las esculturas del Cerro de los Santos como tema de su discurso de ingreso, al apreciar una mezcla entre el arte oriental y el griego, contactando con Fita por sus conocimientos en hebreo y el miedo a la presencia de falsificaciones, al que envió calcos de casi todas las inscripciones, quien a su vez le remitió 8 cartas contestándole a sus consultas (Abascal, 1996: 312 y 1999: 21-22).

El problema se agravó con la compra de 1875 de unas esculturas que fueron ofrecidas hacia inicios de 1874, pues en agosto de 1875 se señala que "Mas de un año ha transcurrido desde que llegaron a mis manos las pequeñas fotografías" de una nueva serie de 27 esculturas, que "En el acto las cedí muy gustoso (...) á D. Juan de Dios de la Rada, mi querido compañero (...) ocupado en redactar su discurso"(Savirón, 1875: 245246), además de un jarrón árabe, "la pieza más importante". Rada (1876b: 595) confirma que recibió las fotos en el verano de 1874 . Se trató por primera vez de 7 falsificaciones egiptizantes de un grupo de 13 falsas que están claramente inspiradas en esculturas e inscripciones jeroglíficas egipcias (Pérez-Accino, 2001: 254-255, 258-259 fig. 2-3), elaboradas por Amat u otra persona, pues según Lasalde (1879 y 1880-81), “El punto donde los adquirió fué Montealegre", e incluían "los [ejemplares] más preciosos (...) adquiridos por él después de sus excavaciones". Por ellas, por primera vez pidió una cifra realmente alta, 22.000 pesetas, que quedaron finalmente en 15.000 , de las cuales 7.500 corresponderían al jarro árabe y las otras 7.500 por las esculturas, es decir, suponía una cifra similar al grupo pagado a Miró por la mejor serie de esculturas (Mélida, 1905b: 35). Por una Real Orden de 17 de junio se envió a Savirón de nuevo a Yecla para adquirirlas y con ellas vinieron también el mayor número de inscripciones falsas (Savirón, 1875: 247 lám. 5). Lamentablemente, como ha señalado Mélida (1903a: 480), "No desconfió Savirón ni un momento de la autenticidad de lo que en Yecla le ofrecieron". Por otra parte, ingresaron en el Museo Arqueológico Nacional en el peor momento, coincidiendo justo con el discurso de ingreso en la Real Academia de Rada (1875a y 1875b). Al formalizarse el ingreso de Rada y la publicación de su discurso en junio de 1875, Savirón (1875: 125) optó finalmente publicar poco antes, desde abril de 1875 , lo resultados de la excavación de 1871 en el Cerro de los Santos.

La procedencia egipcia defendida por Rada (1876b: 599), quien creía que el templo del Cerro de los Santos estaba "consagrado al sol, y que cerca de él existió un colegio de sacerdotes osiriacos é isiacos", y "al ciclo egipcio pertenecen la mayor parte de las estatuas religiosas y divinidades del Cerro de los Santos" (Rada, 1875b: 264), tuvo también otro importante apoyo en los trabajos de Lasalde (1879), quien propugnó un origen egipcio de los pueblos bastitanos, a los que consideraba hispano-egipcios, identificando poco después un culto a Isis (Lasalde, 1880-81) y por Salvador Sanpere i Miquel (1880), que en su Contribución al estudio de la religión de los iberos también identificó un culto a Osiris en el Cerro de los Santos.

Aunque pueda pensarse lo contrario, muy pronto se fue generalizando la idea que existían falsificaciones entre las esculturas e inscripciones compradas. Ya en la reseña del libro de la Rada (1875a), quedaba claro para Hübner (1876: 217) que las inscripciones eran falsas y también algunas de las esculturas. Previamente ya se lo había avisado por carta a Fernández-Guerra, "Los letreros que en ellos se encuentran, son de tal modo contrarios a todo lo que hay de verdaderamente antiguo (...) [que] no puedo forzar mi conciencia a admitirlos desde luego como genuinos" (Hübner, 6-101875, Miranda et alii, 2011: 170 carta $^{\circ} 142$ ). En cambio, Fernández-Guerra, convencido de su autenticidad, le animaba desde 1875 a venir a verlas personalmente a Madrid (Hübner, 28-10-1875, Miranda et alii, 2011: 172 carta $^{\circ} 143$ ), pero la consecuencia final es que la correspondencia entre los dos se interrumpió durante 3 años hasta julio de 1878. El error por la presencia de falsificaciones no sólo afectaba a Rada (1875b: 250), sino que se proyectaba a sus dos principales asesores epigráficos, tema que ocupaba tres cuartas partes del texto, Eduardo Saavedra, "cuya fama y competencia en estas materias alcanza con justicia altísima reputación" y al padre Fidel Fita, por "la poderosa ayuda y generosas enseñanzas, principalmente en lo relativo á la interpretación de las inscripciones" que le había asesorado en todas las inscripciones, pues no conviene olvidar, Hübner las consideraba todas falsas. El propio Lasalde 
acabó pronto asumiéndolo, "se mezclan algunos de origen muy dudoso y otros que á todas luces son apócrifos" (Lasalde, 1880-81).

Un segundo trabajo interesante de Rada es la publicación de los nuevos bronces de Osuna (de la Rada e Hinojosa, 1878), que compró para el Museo Arqueológico Nacional el 26 de agosto de 1876, y al día siguiente, una vez le reveló el vendedor el lugar del descubrimiento, emprendió excavaciones en dicho lugar junto con Francisco Mateos-Gago y Fernández entre el 27 y 29 de agosto. El dato más importante fue la localización de un fragmento del ángulo superior izquierda de la tabla II de la Lex Vrsonensis (de la Rada e Hinojosa, 1878: 121-122) que confirmaba la procedencia de dicho lugar, regresando después a Madrid con las tablas, siendo continuadas las excavaciones por Francisco Mateos-Gago entre octubre y noviembre de 1876 (Salas y Beltrán Fortes, 2008: 247-251).

La Memoria sobre la Necrópolis de Carmona (de la Rada, 1885), con excelentes dibujos y plano de Bonsor (Maier, 1999a: 67), fue resultado de las excavaciones de 225 sepulturas por los propietarios de la necrópolis, Juan Fernández López y George Bonsor entre 1883-85 (de la Rada, 1885: 79-138), a los que incorporó un estudio de sus precedentes y otro comparativo en Occidente y Oriente (de la Rada, 1885: 25-78, 139-150).

Finalmente, redactó la parte de la Protohistoria Ibérica (441-622) con los capítulos de la Época de la Piedra Tallada (Mesolítico), Período Neolítico, Período del Cobre, Período del Bronce y Período del Hierro, que incluye al final las Islas Canarias, en Geología y proto-historia ibéricas (Vilanova y de la Rada, 1893), dentro de la Historia General de España dirigida por Cánovas del Castillo, mientras Vilanova hizo la parte de Geología (1-268), la introducción de Protohistoria general (269-413) y el Paleo o Arqueolítico (415-440).

Durante la hegemonía de los liberales en la Regencia de María Cristina, fue con Riaño uno de los senadores más influyentes en temas culturales y educativos, siendo elegido Senador por Lérida, dentro del sistema caciquil, en las legislaturas de 1886, 1887, 1887-88, 1888-89, 1889-90, y posteriormente por Castellón de la Plana en 1893-94 y 1894-95 (ES.28079-AS.HIS-0362-03), y no por Almería o Granada, donde hubiera sido más lógico.

Su ideología fue claramente "de ideas liberales" (Sentenach, 1901: 640) y como especifica su necrológica en La Ilustración Española y Americana, "en política estuvo afiliado al partido liberal" (de Cuenca, 1894: 84), siguiendo los pasos de su padre, aunque Pasamar y Peiró (2002: 510) lo identifican como "conservador".

\section{LAS APORTACIONES EPIGRÁFICAS DE RODRÍGUEZ DE BERLANGa Y NUMISMÁticas DE ZóBEL DE ZANGRONIZ}

Como epigrafista, Rodríguez de Berlanga siguió realizando aportaciones importantes durante esta etapa, primero el estudio de Los bronces de Osuna con la Lex Ursonensis de Urso-Osuna (Sevilla) del 43 a.C., (Rodríguez de Berlanga, 1873), aprovechando las 3 tablas localizadas a finales de 1870 o inicios de 1871 , que pasaron a la colección del ingeniero Jorge Loring Oyarzábal, adquiridas a Francisco Mateos-Gago, en cuya casa sevillana pudo estudiarlas directamente, preparando parte del libro durante su exilio en Tánger (Rodríguez de Berlanga, 1873: 251). Con la hermana del Marqués de Loring, Elisa, se casó el 8 de noviembre de 1874, que le aportó estabilidad económica en un momento paralelo a la quiebra del Banco de Málaga, de la que era su secretario desde 1856 y del que había dimitido dos años antes, entre 1871-72 (Olmedo, 1985: 73, 75 y 2000: 51). El estudio fue ampliado con Los nuevos bronces de Osuna (Rodríguez de Berlanga, 1876), al aparecer dos nuevas tablas en 1873, que fueron compradas por el Museo Arqueológico Nacional (de la Rada e Hinojosa, 1878), gracias a las gestiones de Cánovas del Castillo, evitando que se vendieran en el extranjero (Paris, 1908 y 1910: 154-163), encargándole el propio Cánovas del Castillo que redactase un libro sobre estas dos nuevas tablas (Rodríguez de Berlanga, 1876: viii-ix).

Estos estudios epigráficos los continuó con Los bronces de Lascuta, Bonanza y Aljustrel (1881c), incluyendo el documento latino más antiguo de Iberia, localizado en Lascuta (Alcalá de los Gazules, Cádiz), del 189 a.C., aparecido en 1840, que acabó en el Museo del Louvre y estudió en París en 1878. La lex metallis Vispascensis, localizada cerca de Ajustrel, que analizó directamente en Lisboa en 1879 (Rodríguez de Berlanga, 1881c: 496, 625), y el bronce de Bonanza (Sanlúcar de Barrameda, Cádiz) de la colección Loring. La importancia del bronce de Lascuta era obvia para Hübner que le indicaba a Fernández-Guerra, "En París he visto el más interesante de todos los monumentos epigráficos que a excepción de los Bronces de Málaga, hasta hoy ha salido de la Península, el Decreto de L. Aemilio Paulo (...) el ingeniero Labinsky (...) lo compró junto a Gibraltar" (Hübner, 1-11-1867, Miranda et alii, 2011: 109 carta $\left.n^{\circ} 60\right)$.

Este libro recibió duras críticas en el seno de la Real Academia de la Historia por sus más férreos adversarios, Fernández-Guerra, "mi oficioso padrino [como Correspondiente de la RAH] me vapuleó de lo lindo", pero lo califica de "folletinista de hopalanda", señalando en una carta a Riaño que "no puedo aprender nada de esto [epigrafía y derecho romano] de él ni de su divino hermano en Jesucristo" (Olmedo, 2000: 100-101), el padre Fita. 
Su última aportación epigráfica importante fue $E l$ nuevo bronce de Itálica y el precio de los gladiadores en el siglo II d.C. (Rodríguez de Berlanga, 1891), en cuya adquisición para el Museo Arqueológico Nacional colaboró con Hübner y Cánovas del Castillo, quien también le encargó el estudio del bronce como refleja su correspondencia con Riaño y Cánovas entre 1889-90 (Gallero et alii, 2008: 247, 249, 251-253). La pieza aparecida en la calle de Medina Sidonio, fue resultado de la apertura de zanjas para la construcción de casas dentro del yacimiento de Itálica y fue adquirida por Rada en agosto de 1889 al coleccionista sevillano Antonio María de Ariza, cuyo nombre permaneció oculto por ser secretario de la Comisión Provincial de Monumentos (Luzón, 1999: 102-103).

Otra faceta menos conocida es su estudio de los pueblos protohistóricos de la Península Ibérica, que inició con Hispaniae Anteromanae Syntagma (Rodríguez de Berlanga, 1881a), estudio introductorio a Los bronces de Lascuta, Bonanza y Aljustrel (Rodríguez de Berlanga, 1881c), cuya importancia en la época es señalada por Hübner (1888: 3) al calificarlo de "el tratado más completo, lleno de extenso saber de aguda crítica, sobre lo que se puede conocer respecto a los más antiguos pobladores de la península". También pretendía completarlo elaborando una recopilación de las fuentes clásicas de la España antigua (Rodríguez de Berlanga, 1903b: 216), que no finalizó.

Uno de las fuentes utilizadas en el estudio fue la numismática, con un trabajo notable, Estudios sobre las leyendas púnicas y tartesias de las monedas antiguas de la Bética (Rodríguez de Berlanga, 1881b: 400475), en una línea ya empezada por Zobel de Zagróniz (1866) con la Noticia de varios monumentos que demuestran la existencia de un alfabeto desconocido empleado antiguamente en alguna de las regiones meridionales de la Bética.

En los últimos años su investigación se orientó hacia artículos más breves de epígrafes y monedas inéditas, pues "pensar yo en escribir otro libro sería locura, dado los grandes desembolsos que los hasta aquí publicados me han producido" (Olmedo, 1985: 76), salvo el catálogo del Museo de Casa-Loring (Rodríguez de Berlanga, 1903a) que pagó Francisco Silvela, su sobrino político y nuevo líder conservador, ya muertos los marqueses y asesinado Cánovas del Castillo. La primera década del siglo XX fue triste al ir perdiendo a "mis amigos íntimos (...) Emilio Lafuente, el obispo de Pamplona [José Oliver Hurtado], su hermano [el presbítero Manuel Oliver Hurtado], Cánovas del Castillo, y ahora el inolvidable Hübner" en febrero de 1901, el Marqués de Casa-Loring en febrero de 1900, la Marquesa en octubre de 1902, su esposa Elisa Loring el 15 de julio de 1903, Theodor Mommsen en noviembre de 1903 y finalmente falleció el propio Rodríguez de Berlanga en su residencia veraniega de Alhaurín el Grande (Málaga) el 3 de junio de 1909 (Olmedo, 1985:76-78 y 2000: 15; Rodríguez Oliva, 1991: 105). Encargado el padre Fita de elaborar su nota necrológica para el Boletín de la Real Academia de la Historia (Olmedo, 2000: 14 n. 8), nunca la llegó a realizar, indicativo de su relación con Rodríguez de Berlanga, el mejor epigrafista español del siglo XIX (fig. 4)

El grupo más importante de numismáticos y coleccionistas españoles se reagrupó en el Círculo Numismático de Sevilla (1870), dirigido por el canónigo Francisco Mateos-Gago y Fernández, catedrático de Teología entre 1857-68 y luego de Hebreo desde 1877 de la Universidad de Sevilla y Francisco Collantes de Terán, que fueron quienes finalizaron y publicaron el Nuevo método de clasificación de las medallas autónomas de España de Delgado (1871-73).

Peor valorado fue el libro Description générale des monnaies antiques de l'Espagne (Heiss, 1870), importante para el ámbito francófono, pero que fue criticado por copiar básicamente las propuestas de Delgado por Zobel de Zangróniz (Mateu, 1949: 67), Rodríguez de Berlanga (1881a: 11) o Hübner (1888: 189, 192). También destaca la publicación del Indicador. Manual de la Numismática española (1890) por Álvaro Campaner y Fuertes, que había sistematizado en

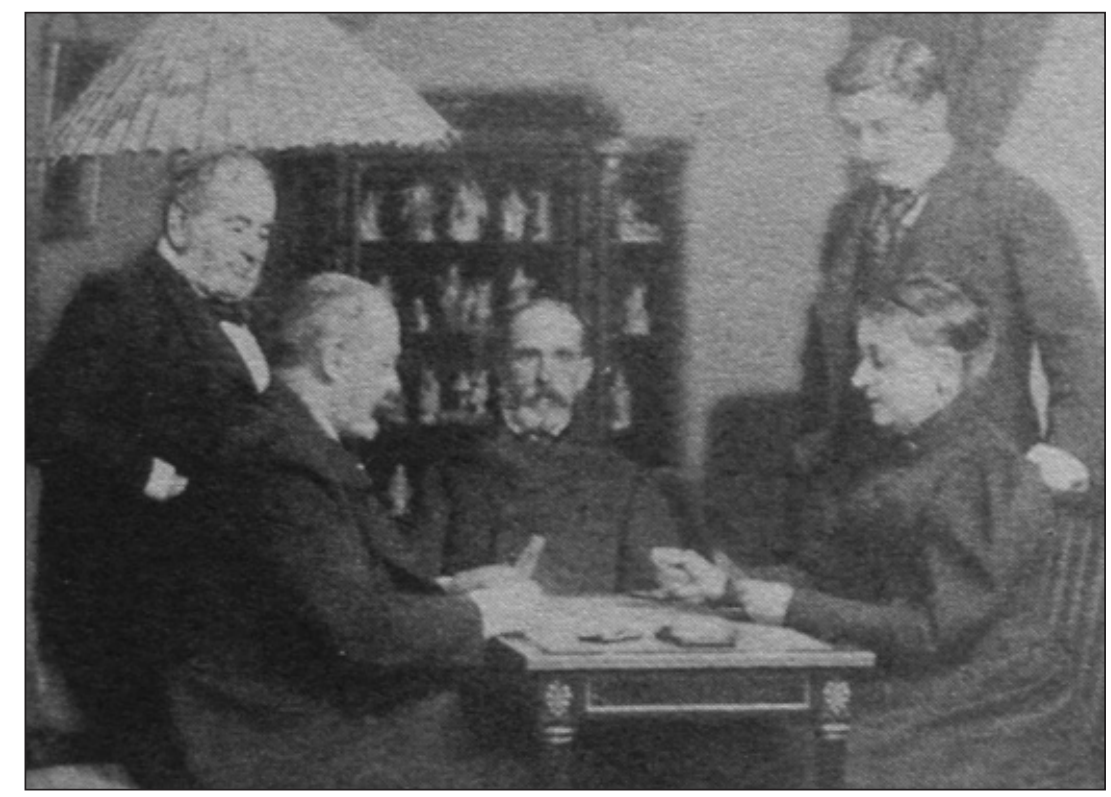

Figura 4. Manuel Rodríguez de Berlanga. 
Numismática Balear (1879) todas las acuñaciones insulares desde los púnicos hasta época moderna. Para Cataluña el trabajo más relevante fue el de Celestino Pujol y Camps (1878) con su Estudio de las monedas de Ampurias y Rhodas.

No obstante, el numísmata más creativo de este periodo fue Jacobo Zóbel de Zangroniz, nacido en Manila el 12 de octubre de 1842, hijo del farmacéutico alemán Jacobo Zóbel y Hirsch, y de María Ana Zangroniz y Arrieta, hija de un juez de la Real Audiencia de ascendencia navarra. Con 6 años fue enviado al Gymnasium de San Juan en Hamburgo para iniciar sus estudios, donde permaneció hasta 1858, y aprendió bien griego y latín, además de las lenguas modernas de inglés, francés e italiano, hasta que con 16 años se trasladó a Madrid para iniciar sus estudios superiores (Hübner, 1897: 168), primero de Bachiller y después la Licenciatura en Ciencias Naturales hasta 1864. Mostró pronto su interés por la numismática, viajando por los museos europeos entre 1862-63 que le permitieron completar su aprendizaje, lo que le permitió publicar trabajos en alemán y francés de 1863. En 1860, cuando Hübner (1897: 167) llegó por primera vez a España, lo conoció en casa de Antonio Delgado, ya coleccionando monedas y solicitándole siempre consejo a Delgado.

Sobre Zobel tenía excelente opinión Hübner, quien le señalaba a Fernández-Guerra, "me ha mandado un excelente trabajo numismático que ha causado admiración al mismo Mommsen (...) Vamos ha hacerlo correspondiente del Instituto porque lo merece altamente" (Hübner, 15-10-1861, Miranda et alii, 2011: 61 carta $\left.n^{\circ} 18\right)$. Después de sus primeros artículos en 1863, en la Real Academia de la Historia fue propuesto como Correspondiente por el Anticuario Delgado, Cardedera y Lafuente el 28 de abril de 1865, siendo elegido el 26 de mayo (Vargas-Zuñiga, 1981: 77-78).

De vuelta a Manila desde 1864 , a solicitud de su padre ya enfermo, se ocupó del laboratorio farmacéutico de la familia (Hübner, 1897: 172) y se involucró en política dentro del partido liberal, siendo elegido primero concejal en 1869 y posteriormente alcalde de Manila en diciembre de 1870, durante el Sexenio Revolucionario. Los cambios políticos en España acabaron convirtiéndolo en sospechoso de revolucionario y fue detenido el 22 de septiembre de 1874, permaneciendo en prisión varios meses en Fuerte Santiago.

Enterado Hübner, escribió a Fernández-Guerra pidiéndole ayuda para "Zobel, el joven más distinguido, quizás, entre sus paisanos de V., que conozco (...) está en la cárcel de Manila bajo la acusación (absurdísima) de haber conspirado en contra España, de haber intencionado de insurgir las Filipinas, y de entregarlas al Gobierno Alemán" (Hübner, 27-12-1874, Miranda et alii, 2011: 163 carta $\mathrm{n}^{\circ}$ 134). Las gestiones de Fernández-Guerra y las del gobierno alemán de Bismark consiguieron su liberación.
Poco después se casó con Trinidad Roxas de Ayala, el 5 de febrero de 1875, con la que tuvo 4 hijos, el primero Enrique en 1877, Alfonso, Fernando y Margarita, los cuales se criaron en España. En esta etapa publicó su obra más valiosa, Estudio histórico de la moneda antigua española desde su origen hasta el Imperio romano (Zóbel de Zangroniz, 1877-80), que dedicó a Delgado, y fue excelentemente considerada por Hübner (1888: 192-193) o Rodríguez de Berlanga (1902: 575) y recibió el premio del Institute de France al mejor trabajo numismático de los últimos 5 años en 1882. A propuesta de Cánovas del Castillo, Rossell, Saavedra y Manuel Oliver, fue elegido para ocupar la vacante de Amador de los Ríos el 10 de mayo de 1878, pero se marchó 4 años después y sólo volvió a España puntualmente en 1886, volviendo a ser Correspondiente por Filipinas desde el 21 de enero de 1892 (Vargas-Zuñiga, 1981: 78; Hübner, 1879: 179).

Regresó a Manila en 1882 (Hübner, 1897: 179) para dedicarse a los negocios ferroviarios. Como representante de la casa Eiffel de París, construyó la primera línea de ferrocarril entre Manila y Tondo acabada en 1885, falleciendo en Manila el 6 de octubre de 1896, con apenas 54 años.

5. El ESPLENDOR DE LOS CONGRESOS INTERNACIONALES DE ANTROPOLOGÍA Y ARQUEOLOgía Prehistóricas Y SU CUlminación EN LisboA (1865-80)

Los Congresos Internacionales de Antropología y Arqueología Prehistóricas sirvieron para proyectar por primera vez a escala europea los descubrimientos arqueológicos realizados en España y Portugal, a la vez que consolidaron la posición de Juan Vilanova como el investigador español más conocido. Su labor también gozó de amplia difusión nacional, pues solía redactar informes de los congresos internacionales que contribuyeron a la divulgación de las principales discusiones científicas.

Primero se celebró un congreso inicial, La Spezia, Italia (1865), consolidándose su denominación a partir del $1^{\text {er }}$ Congreso celebrado en Neuchatel, Suiza (1866), y el $2^{\circ}$ Congreso de París, Francia (1867), ya con representación española y portuguesa, Vilanova y da Costa. En el $3^{\text {er }}$ Congreso de Norwich-Londres, Reino Unido (1868), asistieron Vilanova, Machado y Busk. Para el $4^{\circ}$ Congreso de Copenhague, Dinamarca (1869), marcharon Vilanova, Tubino, Ichaurrandieta y da Silva. Con motivo de la Guerra Franco-Prusiana en 1870, no hubo congreso ese año, y provocó en el futuro una fractura. En el $5^{\circ}$ Congreso de Bolonia, Italia (1871), participó da Silva y en el $6^{\circ}$ Congreso de Bruselas, Bélgica (1872), fueron Ribeiro y da Silva, no asistiendo Vilanova a ambos congresos por la inestabilidad antes de la proclamación de la Primera República Española en 1873. En Bruselas se votó que el congreso fuera bianual. En el $7^{\circ}$ Congreso de Estocolmo, 
Suecia (1874), volvió a asistir Vilanova. En el $8^{\circ}$ Congreso de Budapest, Hungría (1876), no hubo participación española o portuguesa. Este congreso, con menor representación internacional, comienza a mostrar problemas que se reflejarán en la convocatoria de la siguiente sesión, ya cuatro años después, en el $9^{\circ}$ Congreso de Lisboa, Portugal (1880), donde la representación ibérica fue muy importante e intervinieron Vilanova, Caldas, Coelho, Nery Delgado, d'Oliveira, Ribeiro, Martins Sarmento y da Silva. Su celebración en Lisboa, y no en Madrid, fue considerada un fracaso por Vilanova (Actas de la SEHN, 1880: 70), pues "sufrimos el bochorno de que Portugal nos tome en este asunto la delantera", intentando gestionar ese año Tubino y Vilanova con el Ministro de Fomento que se celebrase una sesión extraordinaria en Madrid a la vuelta del congreso de Lisboa, que al final no se logró.

Esta iniciativa de los congresos se paralizó casi 10 años, hasta su celebración de nuevo del $10^{\circ}$ Congreso en París (1889), donde asistieron Vilanova y Nery Delgado, mientras V. Jacques (1891) presentó el estudio antropológico de las excavaciones de los hermanos Siret. Se consiguió celebrar el $11^{\circ}$ Congreso en Moscú, Rusia (1892), sin representación ibérica y otros muchos países europeos occidentales. Finalmente, volvió a ser el $12^{\circ}$ Congreso de París (1900), donde se trató de nuevo de revitalizar estos encuentros, 8 años después, actuando Breuil y Bonsor como secretarios y participando Chil y Naranjo. Francia, tanto en 1889 como 1900 , trató por dos veces de liderar y dar continuidad a estos congresos, pero los arqueólogos alemanes y austriacos no apoyaron estas iniciativas.

Los trabajos presentados en estos congresos suelen recoger las líneas de trabajo más novedosas de la Prehistoria de la Península Ibérica. Si inicialmente Vilanova presentó sus primeras exploraciones en cuevas de Valencia (Vilanova, 1869a), pronto pasó a ofrecer un balance general de las novedades de la arqueología española en los congresos de Copenhage (1869) (Vilanova, 1875a), Estocolmo (1874) (Vilanova, 1876a), Budapest (1876) (Vilanova, 1877) y París (1889) (Vilanova, 1891), a la vez que sintetizaba para los españoles las principales conclusiones de los congresos de Copenhage (1869) (Vilanova y Tubino, 1871) y Lisboa (1880) (Vilanova, 1884b), recogiendo el contenido de los informes que redactó para el gobierno y después utilizó para impartir cursos en el Ateneo de Madrid. Poco puede extrañar que desde un punto de vista internacional, como le señalaba Pierre Paris a León Heuzey, conservador del Départament des Antiquités orientales del Museo del Louvre, Vilanova era considerado "el más autorizado de los prehistoriadores españoles" (E. y J. Gran-Aymerich, 1991: 118) (fig. 5).

Dentro del Paleolítico, la aportación más importante fue el estudio del cráneo de mujer de Homo neanderthalensis, procedente de la Cantera de Forbes (Gibraltar), localizado en 1848 por el teniente Edmund

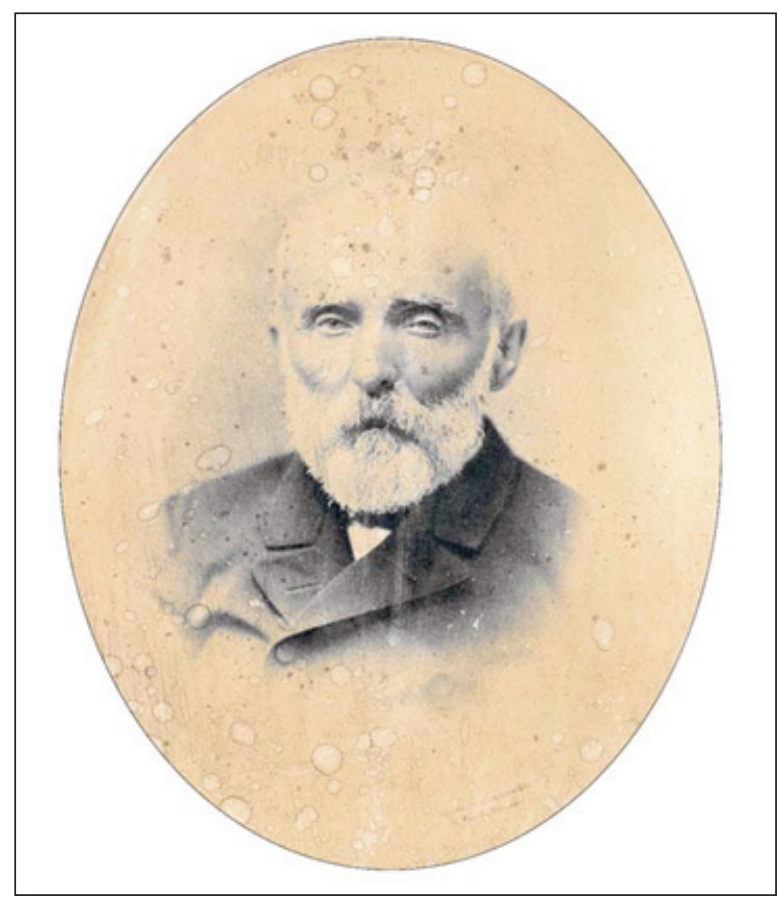

Figura 5. Juan Vilanova y Piera.

Flint, de la Sociedad Científica de Gibraltar, el cual fue estudiado en 1864 por George Busk (1869) y H. Falconer. En Portugal, Ribeiro realizó el estudio de las terrazas fluviales en los ríos Tajo y Sado (Ribeiro, 1873).

La etapa epipaleolítica y mesolítica está representada por el trabajo de Carlos Ribeiro, Joaquim Felipe Nery Delgado y Francisco António Pereira da Costa, miembros de la Comisión Geológica de Portugal (1857-1882), y autores de la Carta geológica de Portugal (1867). Ribeiro excavó entre 1863-64 en Cabeço da Arruda y desde 1880 en Moita do Sebastiâo, concheros epipaleolíticos con enterramientos de Muge, los cuales publicó como Les Kjoekkenmoeddings de la vallée du Tage (Ribeiro, 1884), mientras Pereira da Costa (1865) presentó el estudio de los enterramientos de Cabeço de Arruda (Muge).

Para el Neolítico Final y Calcolítico Inicial, el megalitismo fue el tema que levantó mayor interés, presentándose síntesis del megalitismo en Portugal (da Costa, 1868) y Andalucía (Tubino, 1875). Por otra parte, Nery Delgado, director de la Comisión Geológica de Portugal entre 1882-1908, excavó en 1874 en la necrópolis de Gruta da Furninha (Peniche, Leiria, Centro) (Delgado, 1884).

No obstante, la aportación más significativa, por plantear el problema de su inserción como una etapa específica en la secuencia europea, fue Del cobre y del bronce en España, presentado en el Congreso de Lisboa de 1880, donde Vilanova (1884a) defendió una Edad del Cobre autóctona, que habría precedido a la 
Edad del Bronce, resultado de las excavaciones en el poblado calcolítico de Bolbaite-Ereta del Pedregal (Navarrés, Valencia), que consideró un yacimiento palafítico. Su propuesta quedó reforzada después que el ingeniero Enrique Vilaplana i Juliá excavó en 1884 la Cova de les Llometes (Alcoy, Alicante), que presentaba 6 enterramientos con un ajuar metálico sólo de cobre (Vilanova, 1884c).

Para el Bronce Inicial y Medio, el trabajo más relevante es de Rogelio de Inchaurrandieta y Páez, ingeniero y profesor de la Escuela de Caminos, Canales y Puertos de Madrid (1862-1909), quien en su artículo Noticia sobre la montaña funeraria de La Bastida (Murcia, España) (Inchaurrandieta, 1870a, 1870b y 1875) publicó el primer yacimiento argárico del Sureste ibérico. Del Bronce Final cabe mencionar diversas hachas de bronce presentadas por Possidónio da Silva (1884) y para la Segunda Edad del Hierro merece citarse el trabajo sobre el origen precético de los lusitanos de Martíns Sarmento (1884).

\section{Primeras revistas científicas}

Este periodo asiste al nacimiento de las primeras revistas científicas, primero vinculadas a la Escuela de Minas, el sector económico más dinámico, Anales de Minas (1838-49), después denominada Revista Minera Metalúrgica y de Ingeniería (1850-1936) y las monografías del Memorial Histórico Español. Colección de documentos, opúsculos y antigüedades (1851-65) por la Real Academia de la Historia.

Durante el Sexenio Revolucionario surgieron revistas especializadas, como el Memorial Numismático Español (1866-80), o representativas de sus instituciones como la Revista de la Universidad de Madrid (1869-77), y las tres revistas clave del intento de modernización que surgió durante el Sexenio Revolucionario: la primera etapa de la Revista de Archivos, Bibliotecas y Museos (1871-78, 1883, 1897 1931), que en su segunda época también se llamó Anuario del Cuerpo de Archiveros, Bibliotecarios y Museos (1881-82), los Anales de la Sociedad Española de Historia Natural (1872-) y el Museo Español de Antigüedades (1872-80) del Museo Arqueológico Nacional, cuyo precedente como revista especializada fue la Revista de Bellas Artes, histórico-arqueológica (1867-68), aunque carente de un apartado gráfico.

La calidad y espíritu que tuvo La Ilustración Española y Americana desde 1870 la recogió en una revista científica el Museo Español de Antigüedades, que en su primer número de 1872 cuenta con Tubino, Vilanova, Fernández-Guerra, Madrazo, Demetrio de los Ríos, Fita, Rada, Assas, José Amador de los Ríos, Villa-amil, Savirón, Fernández y González, Saavedra o Janer, incluyendo una sección sobre "tiempos conocidos con el nombre de prehistóricos" en la que escriben
Tubino y Vilanova. Un panel de autores que sólo cabe calificar de brillante. En el n ${ }^{\circ} 2$ de 1873 se incorporan también Hernández Sanahuja, Riaño y Rodrigo Amador de los Ríos. En el $n^{\circ} 6$ de 1875 se suma Codera e Hinojosa en el n 7 de 1877 . El último número como revista, el 10 de 1880, aún tiene a Demetrio de los Ríos, Rodrigo Amador de los Ríos, Rada, Saavedra, Savirón, Tubino y Assas. Sin embargo, estamos ya en el final científico de la generación romántica de la España isabelina con José Amador de los Ríos, Assas, Fernández-Guerra, Hernández Sanahuja, Demetrio de los Ríos, Saavedra, Tubino o Vilanova. Por otra parte, como el contenido de la publicación refleja perfectamente, es el final de una generación de eruditos capaz de trabajar desde la Antigüedad hasta la Edad Moderna y entre el Arqueología y el Arte, que carecía generalmente de una especialización que estaba ya imponiéndose en Europa.

La Restauración monárquica supuso el nacimiento y rápida paralización del primer número del Boletín de la Real Academia de la Historia, al año siguiente de empezar la Revue Historique (1876), encargada a Cayetano Rosell, pero que tardó 3 años en publicarse (1877 (1), 1878 (2), 1879 (3-5)). Pronto fue potenciada por el nombramiento de Antonio Cánovas del Castillo como director de la Real Academia de la Historia (1882-97), con quien se retomó la publicación de la revista con el número 2 entre 1882-83. Por entonces surgió paralelamente el Boletín de la Real Academia de San Fernando (1881-1900), que se publicó mensualmente hasta paralizarse entre 1901-06, coincidiendo con la muerte de Riaño como director de la Academia. Menor éxito tuvo la Revista de Antropología (1874-75, 1880) de la Sociedad Antropológica Española o La Antropología Moderna (1883) de la Academia Española de Ciencias Antropológicas. Otro tanto sucedió con la Revista de Arqueología Española (1880).

Las sociedades arqueológicas situadas en regiones periféricas como Andalucía, Valencia, Baleares, Canarias y Galicia aportaron también revistas especializadas, los mejores indicadores de su dinamismo, caso de la Revista Arqueolójica Sevillana (1870-73), las Memorias de la Sociedad Arqueológica Valenciana (1871-1880), el Museo Balear de Historia y Literatura, Ciencias y Artes (1875-77, 1884-88), la Revista de las Provincias Euskaras (1878-81), el Butlletí de l'Associació d'Excursions Catalana (187890), El Museo Canario (1880-82, 1899-1905), Galicia Diplomática (1882-93), el Boletín de la Sociedad Arqueológica Luliana en Palma de Mallorca (1885-), El Archivo (1886-93) publicada en Denia y después en Valencia por un antiguo miembro de la Sociedad Arqueológica Valenciana, la Revista de Menorca (1888-90, 1896-99, 1902, 1906-34), el Boletín y luego Revista de la Asociación Artístico-Arqueológica Barcelonesa (1891-96, 1896-1913) vinculada al 
Centro Excursionista de Cataluña, y en Oporto, Portugalia (1899-03). En algún caso, sirvieron como órgano de las Comisiones Provinciales de Monumentos, caso de la Revista de Extremadura (1899-1911) para las de Cáceres y Badajoz, pero por los años de su publicación se puede observar la falta de continuidad.

Las revistas más importantes fueron las que tuvieron mayor continuidad, Anales de Minas-Revista Minera (1838-1936) y los Anales de la Sociedad Española de Historia Natural (1872-), que recogieron las contribuciones de los investigadores más vinculados a la ingeniería de minas, geología e historia natural durante la polémica darwinista. Los miembros del Museo Arqueológico Nacional y la Escuela Superior de Diplomática optaron por la lujosa Museo Español de Antigüedades (1872-80), editada por Rada, y los archiveros y bibliotecarios mantuvieron la Revista de Archivos, Bibliotecas y Museos (1871-83). Sin embargo, la suspensión de las dos últimas y la presencia de Cánovas del Castillo dio la hegemonía final al Boletín de la Real Academia de la Historia, quien supo elegir a Fita, con la ayuda de Rada, para dirigir la revista desde 1883 y contaba con financiación anual del Estado dentro de la partida para la Real Academia de la Historia, como también había sucedido con la Revista de Archivos, Bibliotecas y Museos. En Portugal, junto a la Revista Archeologica (1887) de Lisboa, la fundación más tardía del Museo Etnológico Portugués en Belem (Lisboa) propició su mejor revista, O Archeologo Português (1895-1918).

Es importante señalar la ausencia de especialización en las revistas, que también reflejan los arqueólogos españoles, salvo el caso único del Memorial Numismático Español (1866-80) de Álvaro Campaner, beneficiado por un coleccionismo privado de alto poder adquisitivo (Mora Serrano y Volk, 2002). Por otra parte, incluso las revistas específicamente arqueológicas son excepcionales y no tuvieron continuidad como refleja su escasa periodicidad, estando siempre vinculadas a un museo arqueológico como el Museo Español de Antigüedades (1872-80) del Museo Arqueológico Nacional, El Museo Canario (1880-82, 1899-1905) y O Archeologo Português (1895-1918) del Museo Etnológico Portugués. Sociedades arqueológicas como la Sociedad Arqueológica Sevillana y su Revista Arqueolójica Sevillana (1870-73), las Memorias de la Sociedad Arqueológica de Carmona (1887), y la Sociedad Carlos Ribeiro de Oporto con Portugalia (1899-03), o más excepcionalmente las Comisiones Provinciales de Monumentos, como el Boletín de la Comisión de Monumentos de Navarra (1895-1936).

En todo caso, la Prehistoria o la Arqueología tuvo una escasa presencia en las revistas no especializadas, siendo un buen ejemplo que el Boletín de la Real Academia de la Historia sólo tuvo entre 1877-
1902 un $1.29 \%$ de artículos de Prehistoria y Protohistoria, sólo 24 de 1636 artículos, además de algunos de Arqueología dentro de la sección de Historia Antigua con el $14.75 \%$. Más en concreto, de Prehistoria hubo 1 entre 1877-83, 5 entre 188488, 14 entre 1889-93 y 7 entre 1894-98 (Peiró, 1995/2006: 294 gráfico 8, 295-296 gráficos 9-12, 310 cuadro 17). En cambio, la epigrafía, sobre todo por los trabajos del padre Fita, alcanzan 160 con el $8.54 \%$ y la Numismática con 30 supone el $1.60 \%$. Más difícil de evaluar es la Arqueología y Arte, que se agrupan al contabilizarlos juntos con 178 trabajos y el 9.50 \% (Peiró, 1995/2006: 310 cuadro 17).

La Restauración endureció inicialmente el control de la prensa y los libros en la Ley de Imprenta de Francisco Romero Robledo en 1879, que fue el Ministro de Gobernación desde 1876 con Cánovas del Castillo. Sin embargo, los liberales aprobaron la libertad de prensa con la Ley de 26 de julio de 1883 , que hizo despegar las tiradas y calidad del periodismo en España. Así, el mejor periódico de la época, el Imparcial de Madrid, de la familia Gasset, alcanzaba 50.000 ejemplares en 1885 y más de 100.000 en la década de los noventa (Martínez Cuadrado, 1973: 67).

La alta divulgación científica, artística y literaria, con habituales artículos de arqueología y buenas ilustraciones, siempre estuvo bien cubierta por La Ilustración Española y Americana (1870-1921), complementada por La Ilustración Católica (1877-94) o La Ilustración de Madrid (1870-72).

Desde el extranjero, la única revista que prestó interés por la arqueología española fue la Revista de las Universidades del Midi-Sur (1888), de Burdeos y Toulouse, la cual incluía un Bulletin Hispanique (1899), el cual después cambió su nombre a Revue d'Études Anciennes, potenciando su especialización en historia antigua y filología clásica.

\section{Síntesis SOBRe LA ARQUeOlogía de ESPAÑa Y Portugal}

El progresivo incremento de la información disponible sobre la Prehistoria y Protohistoria de la Península Ibérica y el creciente interés desde Europa, hizo necesario la elaboración de síntesis que son indicativas del proceso de maduración de la disciplina. Algunas fueron realizadas por investigadores franceses o alemanes que ya trabajaban en España. Así destacan la de Émile Cartailhac, profesor en la Universidad de Toulouse que aún impartía Prehistoria en la Facultad de Ciencias (1882-89) con Les âges préhistoriques de l'Espagne et du Portugal (Cartailhac, 1886), después de sus misiones en España entre 1880-81. Poco después se publicó un trabajo donde Hübner aprovechó estudios suyos previos para poder ganar el premio Martorell, La arqueología de España (Hübner, 1888). 
En Portugal se realizaron dos obras de síntesis, una de ámbito peninsular, Introducçao a Archeologia da Peninsula Iberica. Antiguidades prehistoricas por A.F. Simoes (1878) y otra específica para Portugal, el trabajo más detallado de J. Leite de Vasconcelos, Portugal Pre-Histórico (1885), además de un libro de introducción a la arqueología por Possidónio da Silva, Noções elementares de archeologia (1878).

En España, una labor importante fueron los manuales elaborados por M. Sales y Ferré, el primero con estudios sobre el origen del hombre y el Paleolítico, Prehistoria y origen de la civilización. Tomo I. Edad paleolítica (Sales y Ferré, 1880), y posteriormente el primer tomo de una Historia Universal donde se estudiaba la Prehistoria y las civilizaciones del Próximo Oriente, Compendio de Historia Universal. Edad prehistórica y período oriental (Sales y Ferré, 1883-85). Aún en la segunda década del siglo XX se seguían utilizando, señalando Pericot (1964: 19) que "no carecía España de un buen manual para su tiempo. La "Prehistoria" de Sales y Ferré, era obra meritoria donde se recogía el esquema que la Ciencia francesa había fijado" para el Paleolítico. Desde un punto de vista introductorio cabe mencionar el Manual de Arqueología Prehistórica de Manuel de la Peña y Fernández (1890).

La primera Historia de España que va a integrar estas etapas fue el volumen elaborado por Vilanova para la Prehistoria y Rada para la Protohistoria, Geología y proto-historia ibéricas (Vilanova y de la Rada, 1893), dentro de la Historia General de España que preparó A. Cánovas del Castillo para la Real Academia de la Historia. Sin embargo, este proyecto fracasó por la poca implicación de quienes participaron, finalizándose sólo 8 encargos de los 28 que estaban planificados, fallando su propio director, Cánovas, Codera, Madrazo, Menéndez y Pelayo, Riaño o Saavedra (Peiró, 1995/2006: 327 n. 118), entre otros.

\section{PRINCIPALES EXCAVACIONES ENTRE 1868-1885}

Un factor importante que trató de estimular las actuaciones arqueológicas fueron los nuevos nombramientos de la figura del Inspector de Antigüedades, a propuesta de la Real Academia de la Historia. Así, para Andalucía, desde 1859, Manuel de Góngora y Martínez lo fue de Granada y Jaén, mientras que Luis Maraver y Alfaro fue nombrado para Córdoba en 1867. Al inicio de la Restauración hubo otra serie de nombramientos, Mariano Vergara para Murcia y Albacete en 1875, Raimundo Pérez Villamil para León y Palencia en 1876 y Enrique Claudio Girbal y Nadal en Gerona desde 1876 hasta 1896 (Maier, 2003a: 37), pero sólo Góngora destacó en este grupo.

En yacimientos paleolíticos cabe citar la primera planimetría de la Cueva Mayor de Atapuerca (Burgos), realizada por Pedro Sampayo y el ingeniero de minas Mariano Zuaznavar (Sampayo y Zuaznavar, 1868). La sierra de Atapuerca fue afectada posteriormente por la construcción de una vía de ferrocarril entre 1896-1901, que funcionó hasta 1910.

Para el Neolítico destaca la excavación en 1869 y 1871 por el gaditano de ascendencia escocesa, Guillermo MacPherson (1870-71), en la Cueva de la Mujer, Mesa del Baño (Alhama, Granada), del Neolítico Medio-Final, estimulado por la publicación de Góngora (1868) de la Cueva de los Murciélagos (Granada). Estas actuaciones que tuvieron continuidad en 1872 y 1875 por Manuel Gómez-Moreno González y finalmente por su hijo Manuel Gómez-Moreno Martínez en 1894. La otra cueva del Neolítico Final que tuvo un estudio fue una cueva sepulcral de la Punta de Torremolinos, a $10 \mathrm{~km}$. de Málaga, actualmente desaparecida, con el Estudio prehistórico sobre la Cueva del Tesoro elaborado por Eduardo J. Navarro Pérez (1884: 7), miembro de la Sociedad Malagueña de Ciencias Físicas y Naturales, quien criticaba "el desprestigio que se encuentran en España, y sobre todo en Madrid" los estudios de Prehistoria.

Del Calcolítico, el estudio más reseñable fue la excavación de la necrópolis de tholoi de Alcalar (Algarve) por Sebastião Filipes Martins Estacio da Veiga, que publicó en Antiguidades Monumentaes do Algarve. Tempos prehistoricos (da Veiga, 1886-91). Estacio da Veiga había realizado sus primeras prospecciones entre 1865-66, siendo encargado desde 1877 de la carta arqueológica del Algarve, siguiendo las instrucciones del Congreso de Estocolmo de 1874, y después organizó el Museo Arqueológico de Faro desde 1880 (fig. 6).

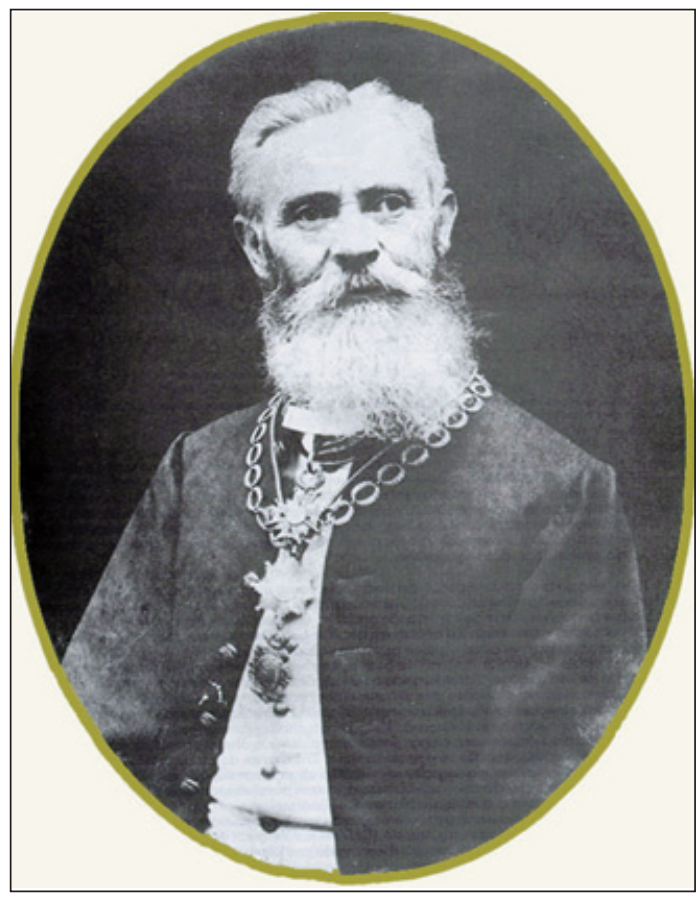

Figura 6. Sebastião Filipes Martins Estacio da Veiga. 
Otra aportación interesante es el intento síntesis sobre el megalitismo ibérico de Sanpere i Miguel, Contribución al estudio de los monumentos megalíticos ibéricos (Sanpere, 1881), además de las aportaciones de Tubino (1876). Entre las actuaciones concretas, en marzo de 1851, Antonio Cortés no fue autorizado por el propietario, Conde la Vega del Sella, a excavar el dolmen de Santa Cruz (Cangas de Onis, Asturias), pero la Comisión de Monumentos de Oviedo le animó a iniciarlas y se descubrieron al menos 10 piedras del dolmen y se excavó parte de su interior. En 1868 trató de retomar la excavación, para lo cual la Comisión de Monumentos de Oviedo le concedió 2.000 reales en marzo de 1868, pero el dinero al final no se libró con el estallido revolucionario (Adán, 1997: 212-213, 226).

En Navarra, la persona más activa en el estudio del megalitismo fue el vocal y luego presidente de la Comisión de Monumentos, el pintor Juan Iturralde y Suit, aunque sus trabajos fueron publicados años después (Iturralde, 1911). En este sentido, la Real Academia de la Historia instó a la Comisión de Monumentos de Navarra en enero de 1887 para el estudio de los megalitos en la vertiente pirenaica ante los descubrimientos que se estaban obteniendo por Julien Lacaze en el Pirineo francés (Lavín, 1997: 410-411).

Para el Calcolítico Final campaniforme destaca el trabajo de Carlos Ribeiro (1878-80) sobre el poblado fortificado de Leceia (Oeiras, Estremadura), en sus Estudos prehistóricos em Portugal. Noticia de algumas estações e monumentos prehistóricos.

De los poblados de la Edad del Bronce, además del estudio del poblado argárico de la Bastida de Totana (Murcia) por Inchaurrandieta (1870a y b; 1875), merece reseñarse el de Santiago Moreno en los poblados argáricos de la Ladera de San Antón y el Cabezo de San Miguel (Orihuela, Alicante), con sus Apuntes sobre las estaciones prehistóricas de la Sierra de Orihuela (Moreno, 1872/1942).

Para contextos de final del Bronce Medio o inicios del Bronce Final I, Recadero de Garay y Anduaga excavó en octubre de 1870 varias necrópolis del Bronce del Suroeste en Huelva, en Barranco Gómez (Almonaster la Real), Fuente del Durasnillo (Almonaster la Real), Cabezo del Águila de Olivarga (Almonaster la Real), Cabezo del Guijarro (Calañas) y Corral Alto (Calañas), estudiando unas 25 tumbas (Garay, 1923: 41-47; Maier et alii, 2000: 242, 243 fig. 26). Este ingeniero de Minas, Garay y Anduaga, también localizó mazos de minero en la mina de Monte Romero (Almonaster la Real, Huelva) y Rodeo del Madroño (Valverde del Camino, Huelva) en febrero de 1870, cuya explotación sitúa en la Edad del Cobre (Garay, 1923: 36-37 lam. 1; Maier et alii, 2000: 240-241).
De las necrópolis orientalizantes, aunque en sus fases más tardías, merece reseñarse las excavaciones de Joaquim Possidónio da Silva en la necrópolis de Olivar de Senhor dos Mártires en Alcacer do Sal en 1875 , localizada el año anterior al realizarse la nivelación del terreno para construir una era, con hallazgos de cerámicas griegas, publicando Sobre a necrópole de Alcácer do Sal (da Silva, 1875 y 1887).

Respecto a la colonización griega, es interesante el trabajo del futuro conservador del Museo de Gerona desde 1896, Joaquín Botet y Sisó, Noticia históricoarqueológica de Emporion (Botet, 1879).

Dentro de la segunda Edad del Hierro, en el ámbito de los pueblos celtas, para Asturias, la excavación más relevante fue la de José María Flores y González, en 1877, en el Castro de Coaña, Villacondite (de la Rasilla, 2000: 31-32), que publicó en su Memoria relativa a las excavaciones de El Castejón en el Concejo de Coaña (Asturias) (Flores, 1878), si bien las campañas continuaron 3 años más entre 1878-80 cuya memoria no se llegó a publicar a pesar de comprometerse la Diputación a editarla (Adán, 1997: 227). En el ámbito celtibérico, destacan las excavaciones en el Cabezo de Alcalá (Azaila, Teruel) entre 1868-72 por el conservador del Museo de Zaragoza, Pablo Gil y Gil.

Para Galicia, merece resaltarse la excavación de castros gallegos entre 1868-69 por José Villa-Amil y Castro, madrileño nacido el 15 de noviembre de 1838 , de ascendencia gallega pues su abuelo paterno, José Villa-Amil era de Mondoñedo (Lugo), a donde regresó su familia (López Cdad y Tostón, 2004: 107), cuya catedral estudió. Residía en Lugo cuando empezó a publicar trabajos sobre Arqueología Sagrada en 1863, culminados con Rudimentos de Arqueología Sagrada (Villa-Amil, 1867). Empezó sus estudios tarde, obteniendo el Bachiller en Lugo el 9 de junio de 1869 (Manso, 2008-09: 245), con 31 años, ingresando como alumno libre después en la Escuela Superior de Diplomática donde se graduó el 25 de octubre de 1871. Realizó a partir del curso 1873-74 la Licenciatura en Derecho, el primer año como alumno libre, pues se incorporó como Oficial de Tercer Grado a la Biblioteca de la Universidad de Salamanca en febrero de 1874, estudios que finalizó en 1877 y alcanzó el grado de Doctor en 1879 en Derecho Civil y Canónico (López Cdad y Tostón, 2004: 109-110; Manso, 2008-09: 246). Sus investigaciones fueron centrándose en los depósitos del Bronce Final con Armas, utensilios y adornos de bronce recogidos en Galicia (Villa-Amil, 1875) y en particular en el mundo castreño de la Edad del Hierro, primero con Antigüedades Prehistóricas y Célticas de Galicia (Villa-Amil, 1873), continuados con Adornos de oro encontrados en Galicia (VillaAmil, 1874) y Los castros y las mámoas de Galicia (Villa-Amil, 1876) (fig. 7). 


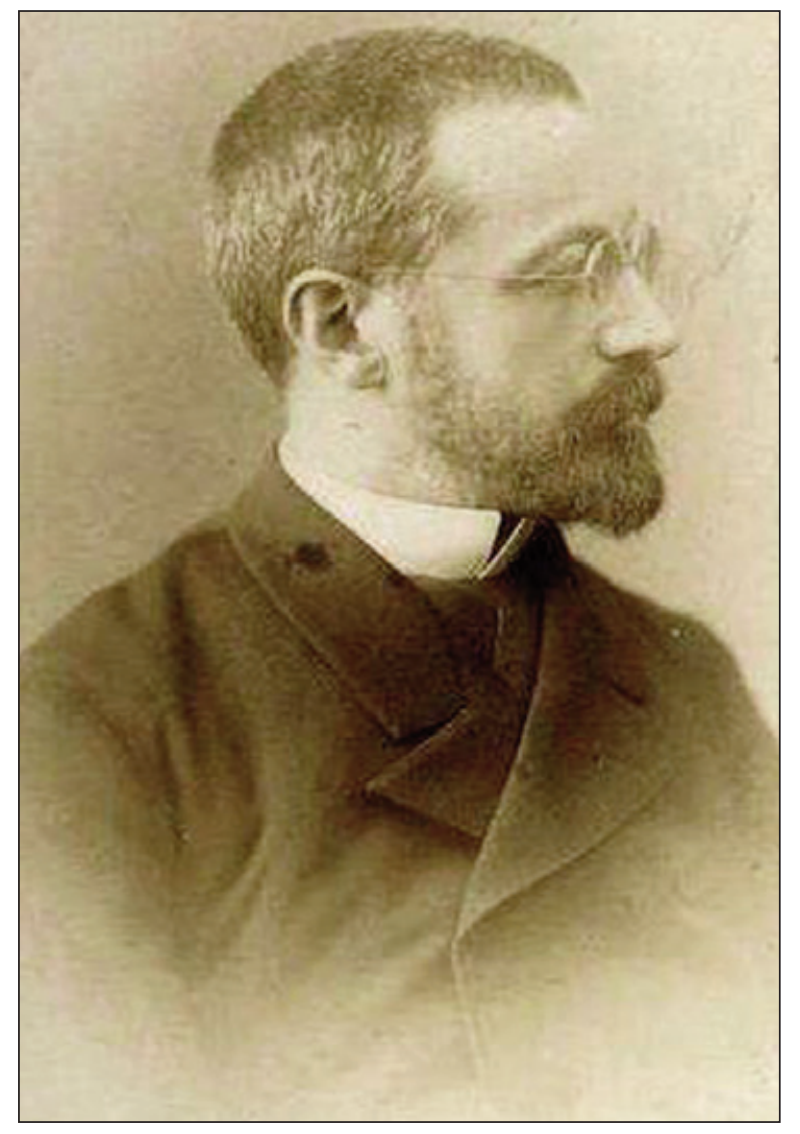

Figura 7. José Villa-Amil y Castro.

En el Norte de Portugal cabe reseñar que Francisco Martins Sarmento inició excavaciones en los oppida de Citania de Briteiros (Güimaraes, Braga) entre 187475 y el castro de Sabroso (Güimaraes, Braga) entre 1876-80, defendiendo un origen precéltico de los lusitanos (Sarmento, 1879), que desarrolló en su libro, Os lusitanos: questões d'ethnología (Sarmento, 1880).

En el ámbito ibérico, aparte del Cerro de los Santos, cabe mencionar la monografía de Aureliano Ibarra y Manzoni (1879) sobre Illici, su situación y antigüedades, donde trató de demostrar que la antigua colonia romana estaba en La Alcudia de Elche y no en Alicante.

En las Islas Baleares una primera aproximación a los monumentos talayóticos de Mallorca y Menorca fue elaborada por Martorell (1879), después de una visita a las islas entre 1875-76, que después amplió a Córcega.

Para las Islas Canarias, Sabin Berthelot, cónsul francés en Tenerife desde 1867, publicó unas Noticias sobre los caracteres jeroglíficos grabados en las rocas volcánicas de las Islas Canarias (Berthelot, 1875/1877) y Antigüedades Canarias (Berthelot, 1879/1980). De Gan Canaria resalta el descubrimiento de la Cueva Pintada (Gáldar, Gran Canaria) con enterramientos en su interior por Diego Ripoche (1883) y el estudio de las momias de Gran Canaria por el médico Gregorio Chil y Naranjo, en su artículo Momias del Barranco de Guayadeque (Ingenio-Agüimes, Gran Canaria) (Chil, 1880b y c).

Entre los yacimientos romanos más destacables, en Portugal se iniciaron las excavaciones en Coimbriga entre 1873-74 por Augusto Filipe Simoes, después de la fundación del Instituto de Coimbra en 1873, quien publicó sus resultados en Introducçao á Arqueología da la Península Ibérica. Antiguidades prehistoricas (Simoes, 1878).

Sobre epigrafía romana en Galicia, Ramón Barros Silvelo hizo un notable estudio en Antigüedades de Galicia (Barros, 1875), algunas de las cuales fueron comunicadas a la Real Academia de la Historia en 1878 (González Ruibal, 2000: 122).

Para Santander cabe resaltar que el Correspondiente de la Real Academia de la Historia desde 1866, Ángel de los Ríos y Ríos (1889; Duque, 1885), exploró en 1885 el campamento romano en Julióbriga (Reinosa, Santander). En León destaca la excavación de una villa romana en Navatejera por Juan Eloy Díaz-Jiménez (1922) en 1885. Y en Madrid merecen reseñarse las excavaciones por José $\mathbf{M}^{\mathrm{a}}$. Escudero de la Peña en La Fuente del Juncal de Complutum (Alcalá de Henares) en 1881, durante la cual se localizó un ara votiva (Maier, 1998: 77).

Un buen ejemplo de la parálisis en las excavaciones durante este periodo es el caso de Itálica, cuyas últimas campañas fueron entre 1872-74, dirigidas por Demetrio de los Ríos, que fueron pagadas por Candelaria Rodríguez, dueña del olivar de Las Coladas, después del hallazgo fortuito de un mosaico romano. Se excavaron diversas viviendas con mosaicos como la Casa de Hylas y la Casa del Patio Rodio, que Demetrio de los Ríos pensaba que podrían corresponder a un palacio, totalizando $851 \mathrm{~m}^{2}$ de mosaicos (Luzón, 1999: 96-97).

Finalmente, para la época islámica cabe citar la localización de una necrópolis en el camino del cementerio de Toledo en 1888 (Maier, 1999c: 19, 114) y el trabajo de los hermanos J. y M. Oliver y Hurtado (1875), Granada y sus monumentos árabes. Las aportaciones más importantes son de Rodrigo Amador de los Ríos, formado como arabista con Simonet en la Universidad de Granada, que publicó primero Inscripciones árabes de Sevilla (Amador de los Ríos, 1875), continuó con Inscripciones árabes de Córdoba (Amador de los Ríos, 1879) y culminó estos estudios con la Memoria acerca de algunas inscripciones arábigas de España y Portugal (Amador de los Ríos, 1883), que lo convierten en el mejor especialista español en inscripciones arábigas de la segunda mitad del siglo XIX. 


\section{CONCLUSIONES ENTRE 1868-85}

9.1. Instituciones educativas: universidades $y$ Escuela Superior de Diplomática

Durante la Restauración sólo hubo un intento por los liberales en mayo de 1886 de dividir el Ministerio de Fomento en uno de Instrucción Pública y de Ciencias, Letras y Bellas Artes, y otro de Obras Públicas, Agricultura, Industria y Comercio. El nuevo Ministerio de Instrucción Pública debía contar con dos direcciones generales, una de Establecimientos de Enseñanza y otra de Ciencias, Letras y Bellas Artes. Sin embargo, la oposición a esta medida terminó con el rápido cese del ministro Eugenio Montero.

En el Plan de Estudios de 1857, la Licenciatura era de 2 años $\left(4^{\circ}\right.$ y $\left.5^{\circ}\right)$, más un tercero de Doctorado $\left(6^{\circ}\right)$, y carecía de asignaturas de Historia, que se concentraban en el $3^{\circ}$ curso de Bachiller con Historia General e Historia de España. Su modificación se aprobó por Real Decreto el 13 de agosto de 1880, donde se estableció una Licenciatura de Filosofía y Letras de 3 años y más un cuarto año de Doctorado: en $1^{\circ}$, se estudiaba Historia Universal [antigua] (1), Literatura General, Lengua Griega (1) y Metafísica (1); en $2^{\circ}$, Historia Universal [moderna] (2), Metafísica o Historia de la Filosofía (2), Lengua Griega (2) y Literatura Griega y Latina; en $3^{\circ}$, Historia Crítica de España, Literatura Española y Lengua arábiga o Hebreo; y el doctorado incluía Historia Crítica de la Literatura Española y Estética. Estos contenidos reforzaron notablemente la disciplina de Historia, pero su efecto no se empezó a notar hasta 1884 cuando finalizó la primera promoción con el nuevo plan de estudios.

Más contenidos en Arqueología se impartían en la Escuela Superior de Diplomática, pero no puede hablarse estrictamente de una formación de élite como a veces se ha sugerido, aunque sí se adelantó aspectos en 1856 que fueron recogidos en el Plan de Estudios de 1880. Los alumnos entraban con 16 años, una vez finalizado el bachillerato, y obtenían el grado con 19 años, después de cursar tres años, donde aprendían los rudimentos que irían perfeccionando una vez comenzaban a trabajar. La carga docente era pequeña, con sólo 3 asignaturas anuales de 3 , o excepcionalmente 4 , horas semanales. La plantilla docente del $1^{\circ}$ curso trabajaba en el Archivo Histórico Nacional, la de $2^{\circ}$ curso en el Museo Arqueológico Nacional y la de $3^{\circ}$ curso en la Biblioteca Nacional. Del Museo Arqueológico Nacional estaban Juan de Dios de la Rada, Jefe de Tercer Grado con Numismática y Epigrafía en $2^{\circ}$ y Manuel de Assas y de Ereño, Ayudante de Segundo Grado con Arqueología elemental de $2^{\circ}$. La excepción fue Juan Facundo Riaño, con Teoría e Historia de las Bellas Artes en la Edad Antigua, Media y Renacimiento de $3^{\circ}$, director del Museo de Reproducciones Artísticas entre 1878-1901. Tanto Assas como Riaño impartieron una Arqueología Monumental, vinculada con las Bellas Artes.
El intento de suprimir la Escuela en 1873, durante la Primera República, trató de reforzar las asignaturas de la Facultad de Letras con optativas procedentes de la Escuela Superior de Diplomática como Arqueología e Historia del Arte de Assas y Epigrafía, Glíptica y Numismática de Rada, e incrementar el estudio de las lenguas, y junto al Árabe y el Hebreo, Caldeo y Rabínico, se introducía el Sanscrito, pero el proyecto fracasó ese mismo año.

La Restauración muestra el progresivo desinterés por los estudios de archivero y bibliotecario impartidos por la Escuela, decreciendo el número de alumnos a 82 en 1888-89, 62 en 1891-92, 56 en 1895-96 y 21 en 1899-1900, de los cuales la mayoría eran alumnos libres ese último año, pues sólo 2 alumnos asistían a cada una de las 12 asignaturas.

Los neocatólicos del Marqués de Pidal consiguieron crear nuevas plazas en la Escuela Superior de Diplomática para personas afines, primero una para el abogado Eduardo de Hinojosa, que se ocupó de la Geografía Histórica en 1882, la antigua Geografía Antigua y de la Edad Media que impartió Delgado, y después para el antiguo presidente de Juventud Católica, Catalina García, que impartió la cátedra de Arqueología y Ordenación de Museos desde 1885. Su nombramiento buscaba posicionar a un neocatólico en un ámbito científico, la Prehistoria, que se consideraba peligroso, o al menos sospechoso, para la iglesia, por su relación con el darwinismo. Otro tanto sucedió con la cátedra de Geología de la Universidad Central, al dividirse la cátedra que impartía Vilanova, la cual fue adjudicada en 1877 al Marqués del Socorro, José Solano y Eulate, defensor de postulados claramente creacionistas. Sus efectos fueron de larga duración porque en 1900, al suprimirse la Escuela, Catalina García pasó a ser el primer catedrático de Arqueología, Epigrafía y Numismática hasta 1911 e Hinojosa de Historia Antigua y de la Edad Media en la Universidad Central hasta 1914.

9.2. Instituciones oficiales: Real Academia de la Historia, Museo Arqueológico Nacional y Comisiones Provinciales de Monumentos Históricos y Artísticos

La Real Academia de la Historia mantuvo un perfil poco especializado durante el periodo de 1874-1910 estudiado por Peiró. Sólo incorporó entre sus miembros a un 36.89 \% con algún grado de especialización histórica, mientras dos tercios de los académicos carecían de ella. De ese $37 \%$, un $13.09 \%$ se habían formado en la Escuela Superior de Diplomática y un 9.52 $\%$ eran titulados en Filosofía y Letras.

El Gabinete de Antigüedades también experimentó durante la Restauración una evidente decadencia porque la persona elegida para desempeñar el puesto de Anticuario entre 1866-94, el crítico literario y drama- 
turgo Aureliano Fernández-Guerra, un prometedor epigrafista en su juventud (Fernández-Guerra, 1834/2010: 252-273 y 1867b), entre los 12 y los 22 años según sus palabras, cuyas aportaciones fueron decayendo al orientar su principal investigación hacia la crítica literaria, "en junio de [1]838 regresé á Granada; y desde esta época data mi frialdad en el estudio de las antigüedades, y mi afición a la bella literatura" (Fernández Guerra, 1839/2010: 308, 310), coincidiendo que fue encargado el curso 1838-39 de impartir la cátedra de Literatura e Historia en la Universidad de Granada. Esta decadencia ya se refleja en su contestación al discurso de ingreso de Rada (Fernández-Guerra, 1875a), dos años después de su elección como Bibliotecario Perpetuo de la Real Academia Española, que le obligó a dedicarse más a esta segunda institución. Su nombramiento mantuvo al Gabinete de Antigüedades relativamente desvinculado de la Escuela Superior de Diplomática (ESD) y del Museo Arqueológico Nacional (MAN), cargos directivos que ocupó de la Rada entre 1876-1900 y 1891-1900. Previamente, ni Francisco Bermúdez de Sotomayor, director del MAN entre 1881-86, ni Castellanos de Losada, director del MAN entre 1886-91, fueron elegidos Numerarios. Tampoco pudo acceder a la Academia de la Historia el catedrático de Arqueología de la ESD entre 1867-1880 y conservador en el MAN, Manuel de Assas (fig. 8).

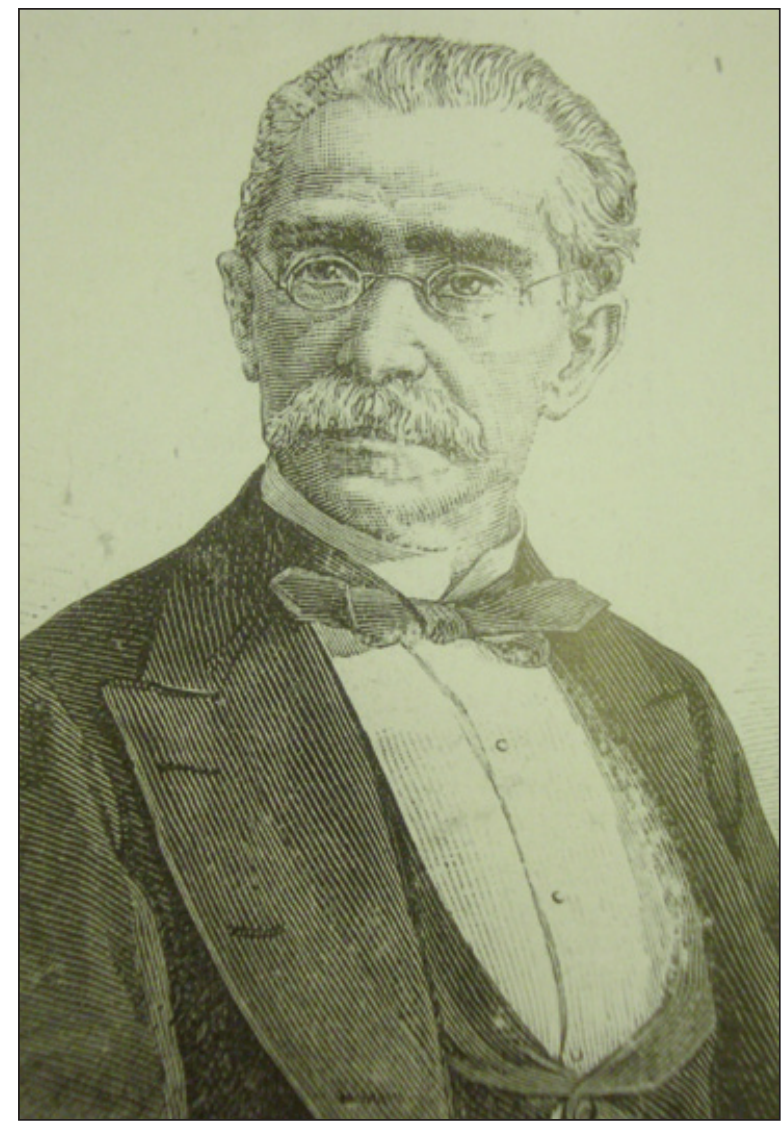

Figura 8. Aureliano Fernández-Guerra y Orbe. La Ilustración Española y Americana.
El desinterés que tuvo la Real Academia de la Historia y su Anticuario por la Prehistoria y el problema del origen del hombre queda perfectamente reflejado en el rechazo a la petición de Vilanova en 1872 de poder dedicar su libro Origen, naturaleza y antigüedad del hombre a la Real Academia de la Historia. Sólo en 1887 logró ser nombrado Correspondiente, apoyado por los liberales Rada, Fabié y Fernández y González, sin el significativo apoyo del neocatólico y Anticuario, Fernández-Guerra, pero rápidamente se produjo su nombramiento como Numerario en 1889, a propuesta de Cánovas del Castillo, que contestó su discurso, lo que supuso la admisión en la Academia de la Prehistoria como disciplina histórica.

La pérdida de peso en el ámbito de las antigüedades de la Real Academia de la Historia fue asumida por el Museo Arqueológico Nacional, creado al inicio del periodo, por Real Decreto el 20 de marzo de 1867, pero su consolidación tampoco fue fácil. No se inauguró hasta el 9 de julio de 1871 y la construcción de su sede definitiva llevó casi 26 años hasta la inauguración del edificio el 11 de noviembre de 1892 para poder celebrar el IV Centenario del Descubrimiento de América. En todo caso, la exhibición de las colecciones no se abrió hasta el 5 de julio de 1895, 28 años después.

Institucionalmente, al principio se trató de mantener un lazo con la Escuela Superior de Diplomática y se nombró a su director, el médico higienista Pedro Felipe Monlau, primer director del museo entre 186768. La entrada de un especialista como Amador de los Ríos a la dirección en 1868 quedó frustrada por su cese con la revolución de septiembre de 1868. A partir de entonces empezó una etapa con el médico y poeta salmantino Ventura Ruiz Aguilera, director entre 186872 , sucedido por el dramaturgo Antonio $\mathbf{M}^{\mathrm{a}}$. García Gutiérrez entre 1872-81, durante la cual Rada se encargó de buena parte de la gestión más especializada del museo. Con la llegada de los liberales y la entrada de Gayangos como Director General de Instrucción Pública se primó el criterio de antigüedad dentro del Cuerpo de Archiveros y Bibliotecarios, positivo por tratarse de buenos conocedores de la institución, pero hizo que llegaran a la dirección con bastante edad, lo que restó eficacia a su labor. Primero fue Bermúdez de Sotomayor entre 1881-86, después Castellanos de Losada entre 1886-91 y finalmente Rada entre 18911900. Por otra parte, desde marzo de 1881, se nombró a los directores de los museos de Tarragona, Barcelona, Valladolid, Granada y Sevilla entre los miembros del Cuerpo de Archiveros y Bibliotecarios.

El Reglamento de las Comisiones Provinciales de Monumentos de noviembre de 1865 no sufrió apenas modificaciones, salvo un punto introducido en diciembre de 1881, siendo Riaño nuevo Director General de Instrucción Pública, modificando los criterios de la restauración de los edificios monumentales. En todo 
caso, las Comisiones Provinciales de Monumentos no funcionaron adecuadamente durante la Restauración, en principio por la ausencia de un Plan General de Excavaciones de ámbito nacional. Más habitualmente por la falta de nombramientos y renovación por fallecimiento de los miembros que las conformaban. A ello se sumó el escaso nivel científico de muchos de los correspondientes elegidos. Finalmente, por la relativa indiferencia de los gobernadores civiles que presidían estas comisiones y no las convocaban.

\subsection{Clases medias burguesas y sociedades arqueológicas}

Los defensores de las teorías darwinistas, muchos de ellos médicos, se agruparon en Madrid bajo el paraguas de la Sociedad Antropológica Española (1865) y en la Sociedad Antropológica de Sevilla (1871-74), mientras que los naturalistas lo hicieron en la Sociedad Española de Historia Natural (1871), que acabó integrando a algunos de los anteriores. Sin embargo, la Real Academia de la Historia marginó a los partidarios de las tesis darwinistas y nunca los eligió como Correspondientes. Por otra parte, el Ateneo de Madrid, especialmente durante el Sexenio Revolucionario, fue uno de los lugares de discusión de las teorías darwinistas, aunque las conferencias anuales a partir del año 1868 fueron impartidas por Vilanova desde una perspectiva creacionista, desde los cursos El hombre fósil y La geología aplicada al estudio del Hombre Primitivo.

La supresión de la Academia Real de Arqueología y Geografía del Príncipe Alfonso, con la revolución de 1868, dejó un vacío entre la burguesía aficionada a la arqueología, lo que impulsó el nacimiento de sociedades de ámbito regional o provincial, caso de la Sociedad Arqueológica Valenciana (1871-81), la Asociación Catalana de Excursiones (1878), El Museo Canario (1879) o la Sociedad Arqueológica Luliana (1881) de Palma de Mallorca.

En todo caso, la burguesía urbana siguió asumiendo los estudios arqueológicos por la falta de suficientes especialistas en las universidades, Museo Arqueológico Nacional, Escuela Superior de Diplomática y Real Academia de la Historia. Entre ellos nos encontramos con comerciantes (Ariza), médicos (Chil y Naranjo, Béthencourt Alfonso, Manuel Fernández López, Verneau), farmacéuticos (Zóbel de Zangroniz, Sepúlveda, Juan Fernández López), profesores de colegios religiosos (Lasalde), abogados (Rodríguez de Berlanga, Sanz de Sautuola), notarios (Costa), periodistas (Tubino), cónsules (Berthelot), ingenieros de caminos (Inchaurrandieta) y de minas (Garay, Zuaznavar, Henri y Louis Siret), arquitectos (Possidonio da Silva, Demetrio de los Ríos, Velázquez Bosco) o pintores (Iturralde, Bonsor), los cuales a veces llegaron a ser elegidos correspondientes de la Real Academia de la Historia o de la Real Academia de Bellas Artes de San Fernando.

\subsection{Legislación y financiación de las excavacio- nes arqueológicas}

La etapa entre 1868-85 marca una clara decadencia en la inversión e interés por la arqueología. Nunca se retomó el Plan General de Excavaciones que ya había sido informado favorablemente por la Real Academia de la Historia en mayo de 1868 , paralizado con la revolución de septiembre de 1868 y apenas hubo financiación por parte de las diputaciones provinciales, con un hundimiento en el número de excavaciones arqueológicas. No deja de sorprender este desinterés porque Cánovas del Castillo, varias veces Presidente del Gobierno, era aficionado a la arqueología y además fue Director de la Real Academia de la Historia entre 1882-97.

Hubo intentos de reforma desde el punto de vista legislativo, como el borrador de una Ley de Monumentos que redactó Demetrio de los Ríos, vicepresidente de la Comisión Provincial de Monumentos de Sevilla en 1875, contando con el apoyo de varias Comisiones Provinciales de Monumentos. El proyecto más importante fue impulsado por un ministro liberal, el marqués de Sardoal, que encargó en diciembre de 1883 la creación de una comisión que debía elaborar en 3 meses una Ley de conservación de Antigüedades Españolas, pero la entrada en el gobierno de los conservadores con Cánovas del Castillo y su ministro, el neocatólico Alejandro Pidal y Mon, paralizó el proyecto.

Pese a lo que pueda pensarse, el inicio de la Restauración supuso el final de una etapa muy activa de las revistas durante el Sexenio Revolucionario, cesando la publicación de la Revista de la Universidad de Madrid (1869-77), la Revista de Archivos, Bibliotecas y Museos (1871-78), el Boletín de la Real Academia de la Historia (1877-79), reanudado en 1882, el Memorial Numismático Español (1866-80), el Museo Español de Antigüedades (1872-80) o las Memorias de la Sociedad Arqueológica Valenciana (1871-1880).

\subsection{Los arqueólogos}

El aspecto más llamativo es la escasa especialización de los arqueólogos españoles, con una formación de anticuarios, capaces de afrontar temas muy variados entre la Protohistoria y la Edad Media, como reflejan bien los trabajos publicados en el Museo Español de Antigüedades, pero poco cualificados, lo que habría permitido aportaciones más elaboradas. Derecho fue lo que estudiaron Assas, Costa, Fernández-Guerra, Rada, Riaño o Sanz de Sautuola, y varios de ellos también trabajaron como abogados, caso de Fernández-Guerra en Granada, Rada, Costa y Rodrigo Amador de los Ríos en Madrid o Riaño en el despacho de Rada. La generación de los formados en la Escuela Superior de Diplomática no accedió a puestos relevantes hasta la 
década de los años ochenta, caso de Mélida como conservador en el Museo Arqueológico Nacional desde 1881 o Catalina García en la cátedra de Arqueología de la Escuela a partir de 1885 .

El control académico fue realizado por una generación de arqueólogos andaluces, iniciada por José Amador de los Ríos y Antonio Delgado, liberales de Sevilla, Huelva y Córdoba, con especial actividad entre 1840-70, la cual fue sustituida progresivamente por un grupo liberal de Granada, promocionado por Delgado y Amador de los Ríos, encabezado por Aureliano Fernández-Guerra, al que se unió con 10 años menos, Juan de Dios de la Rada y Juan Facundo Riaño, activos especialmente entre 1870-85 y de orientación liberal. La excepción fue Fernández-Guerra, quien procedente de una familia liberal, se inclinó progresivamente a los postulados neocatólicos después de haber sido declarado cesante, primero por la Unión Liberal entre 1854-56 y luego por la revolución de 1868 hasta 1875 (fig. 9).

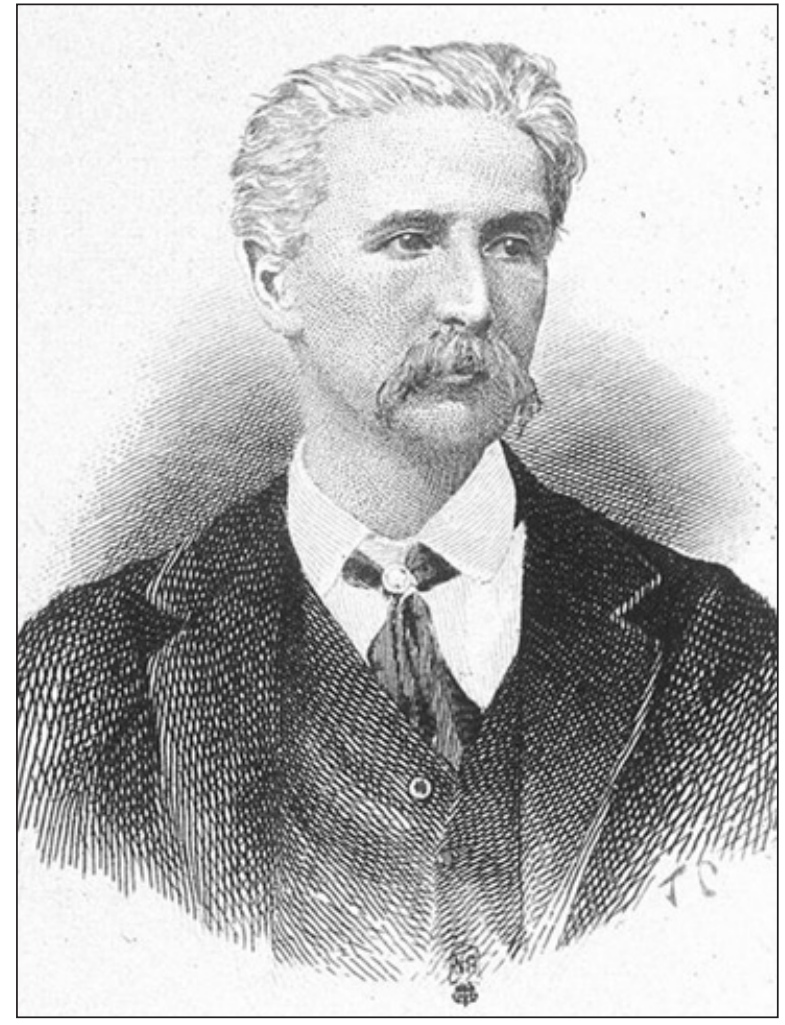

Figura 9. Juan Facundo Riaño.

La Ilustración Española y Americana.

Estas dos generaciones fueron sustituidas definitivamente por un grupo formado en la Escuela Superior de Diplomática, promocionado por Rada, que incluyó a Catalina García, nacido en Guadalajara y cuyo padre se trasladó a Madrid, y Mélida, nacido en Madrid. Continuó el goteo de profesores procedentes de las universidades de Sevilla y Granada en dirección a la
Universidad Central, caso de Machado que marchó en 1883 o Sales y Ferré en 1899, pero abandonaron su interés por la Prehistoria y sus especialidades fueron otras, Zoografía y Sociología.

De todos ellos, sólo presentan formación en el extranjero el geólogo Vilanova, con 4 años postdoctorales en París entre 1849-53, el único becado por el gobierno, y el filólogo García Ayuso en la Universidad de Munich durante 2 años y medio entre 1868-71. El único investigador que realizó sus estudios completos en el extranjero, tanto de licenciatura como de doctorado, fue el médico canario Chil y Naranjo entre 184958. Como puede observarse, Vilanova y Chil se formaron en la etapa precedente, y la marcha a Alemania de García Ayuso estuvo vinculada a su exilio por el estallido revolucionario de 1868, como también le sucedió al epigrafista y jesuita Fidel Fita, que marchó a Francia entre 1868-70. En algunos casos, la muerte prematura privo de algunas de las personas mejor formadas como el orientalista Rivadeneyra en 1882 con 40 años, Zóbel de Zagroniz en 1896 con 54 años o el propio García Ayuso, fallecido en 1897 con 52 años. Por otra parte, no consiguieron plaza universitaria algunos de los mejor preparados, caso de Rodríguez de Berlanga, Joaquín Costa o García Ayuso.

Desde un punto de vista institucional, el arqueólogo más importante de este periodo fue claramente Juan de Dios de la Rada y Delgado, que dirigió la Escuela Superior de Diplomática entre 1876-1900 y detentó la Cátedra de Arqueología y Numismática (1856-63), Numismática Antigua y de la Edad Media (1863-67) y Numismática y Epigrafía (1868-1900). Además, en el Museo Arqueológico Nacional debió ejercer una labor complementaria al director, primero siendo Jefe de Tercer Grado con el poeta Ventura Ruiz Aguilera, cuando se inauguró al público en 1871, después siendo Jefe de Segundo Grado con el dramaturgo Antonio García Gutiérrez, entre 1872-1881, alcanzando finalmente el puesto de director entre 1891-1900. Por otra parte, dirigió la revista arqueológica más importante de este periodo, el Museo Español de Antigüedades (1872-80). Sin embargo, careció de una proyección exterior por su investigación poco especializada y su no participación en los congresos internacionales, en parte quizás por la ausencia de apoyo institucional para los gastos de desplazamiento, siendo llamativa la falta de correspondencia de Hübner con Rada.

La situación opuesta es la que muestra Juan Vilanova y Piera, el geólogo y prehistoriador español más importante de la Restauración, pues si su investigación es muy genérica, salvo en su defensa de una Edad del Cobre que habría precedido a la Edad del Bronce, resultado de los datos de las excavaciones en el poblado calcolítico de Bolbaite-Ereta del Pedregal (Navarrés, Valencia), su participación regular en con- 
gresos internacionales hicieron que sus trabajos tratasen de recoger las novedades de la arqueología española en los congresos de Copenhage (1869), Estocolmo (1874), Budapest (1876) y París (1889), a la vez que sintetizaba para los españoles las principales conclusiones de los congresos de Copenhage (1869) y Lisboa (1880).

En todo caso, los dos principales arqueólogos españoles del periodo estuvieron afectados por duras polémicas. Vilanova por la no aceptación de las pinturas rupestres paleolíticas descubiertas por Sanz de Sautuola y, ya dentro de España, le perjudicó el duro debate entre darwinistas y creacionistas. En el caso de la Rada, por la no admisión del arte ibérico, identificado a partir de las esculturas del Cerro de los Santos, en cuyo conjunto se incluían inscripciones falsas y de algunas esculturas. La insuficiente formación científica de ambos investigadores en Prehistoria y Protohistoria y la modesta consideración que sobre ellos tenían sus colegas extranjeros minimizó el notable interés de sus trabajos.

La nula participación de arqueólogos españoles fuera de las fronteras españolas sólo tienen la excepción de la excavación en la necrópolis de Deir el Medina de la tumba del artesano Sennedjem, de la XIX Dinastía, por el cónsul español Eduardo Toda y Güell en 1886.

\subsection{Obras más representativas}

Los trabajos más relevantes de este periodo son puntuales y buen reflejo del panorama científico de la época. Destaca especialmente la numismática, con la publicación final del trabajo redactado durante años de Delgado (1871-73), Nuevo método de clasificación de las medallas autónomas de España y la síntesis de Zóbel de Zangroniz (1877-80), comenzada a escribir en la década de los sesenta, Estudio histórico de la moneda antigua española desde su origen hasta el Imperio romano, y que en ambos casos responden a la etapa precedente. En epigrafía también continuó el sólido trabajo de Rodríguez de Berlanga con tres aportaciones muy relevantes, Los bronces de Osuna (Rodríguez de Berlanga, 1873), Los nuevos bronces de Osuna (Rodríguez de Berlanga, 1876) y Los bronces de Lascuta, Bonanza y Aljustrel (Rodríguez de Berlanga, 1881c), mientras que la epigrafía árabe tuvo su primer estudio de conjunto en la Memoria acerca de algunas inscripciones arábigas de España y Portugal (Amador de los Ríos, 1883) (fig. 10).

En Prehistoria destaca el primer intento de síntesis sobre los hallazgos prehistóricos en España, Origen, naturaleza y antigüedad del hombre (Vilanova, 1872a), un trabajo heredero también de la fase anterior pues ya estaba redactado en 1868. La otra aportación

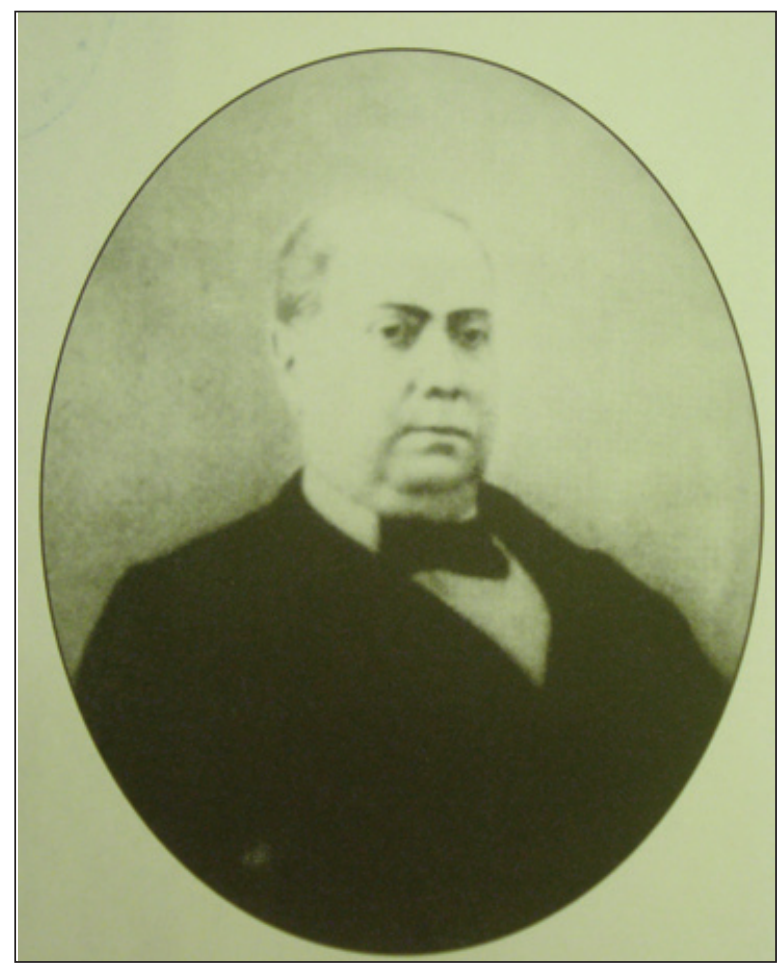

Figura 10. Antonio Delgado y Hernández.

relevante es el opúsculo de Sanz de Sautuola (1880), con el descubrimiento del arte prehistórico magdaleniense en la Cueva de Altamira, en sus Breves apuntes sobre algunos objetos prehistóricos de la provincia de Santander. A ellos cabe sumar el informe de Verneau (1887) sobre su misión científica en Canarias entre 1876-78, Rapport sur une mission scientifique dans l'Archipiel Canarien. No es fácil destacar un libro de Rada sobre Protohistoria porque carecía de una formación especializada.

Entre los filólogos, ya había pasado la mejor época de arabistas como Gayangos o Saavedra y apenas cabe destacar la primera aportación de García Ayuso (1871), El estudio de la filología en su relación con el sánskrito (1871), que fue traducido al francés en 1884, o la Gramática de la lengua arábiga de Moreno Nieto (1872: vi), un encargo del gobierno a propuesta de Amador de los Ríos y Gayangos, que fue entregado para su publicación casi 10 años antes, en 1863, y cuya redacción corresponde a la etapa precedente.

\section{Agradecimientos}

Este trabajo, elaborado a lo largo de varios años, se adscribe al Grupo de Investigación Hum F-003 de la Universidad Autónoma de Madrid, sobre estudios historiográficos, dirigido por J. Blánquez. Queremos agradecer la discusión de aspectos de la historia de la arqueología española del siglo XIX con Jorge Maier, Alicia Canto y Gloria Mora. 


\section{Bibliografía}

Abascal Palazón, J.M. (1996): "Fidel Fita y la epigrafía hispano-romana". Boletín de la Real Academia de la Historia, 193 (2): 305-334.

Abascal Palazón, J.M. (1999): Fidel Fita. Su legado documental en la Real Academia de la Historia. Real Academia de la Historia. Madrid.

Abascal Palazón, J.M. (2004): “Aureliano FernándezGuerra y Orbe". En M. Ayarzagüena y G. Mora (eds.): Pioneros de la Arqueología en España del siglo XVI a 1912. Zona Arqueológica, 3: 293-298.

Adán Álvarez, G.E. (1997): "Intervenciones arqueológicas de la Comisión de Monumentos Históricos Artísticos de Oviedo (1844-1978)". Lancia, 2: $207-$ 233.

Aguado y Alarcón, J. de D. (1875-76): “El Cerro de los Santos. Una aclaración". Revista de Historia Latina, 2 (1): 1-3 y 3: 241.

Ahrens, H. (1828/1841): Curso de Derecho Natural o Filosofía del Derecho. I-II. Boix editor. Madrid.

Alemany y Bolufer, J. (1895): Hitopadeza o Provechosa enseñanza. Imprenta de la Viuda e Hijos de P.V. Sabatel. Granada.

Alemany y Bolufer, J. (1896): Bhagavad Gita o Poema Sagrado. Establecimiento Tipográfico de Alfredo Alonso. Madrid.

Alfaro Asins, C. (1993): "Las colecciones numismáticas del M.A.N.”. en A. Marcos Pous (ed.): De Gabinete a Museo. Tres siglos de historia. Museo Arqueológico Nacional (Madrid, 1993). Museo Arqueológico Nacional-Ministerio de Cultura. Madrid: 147-158.

Almagro Cárdenas, A. (1897): “Catálogo de los manuscritos árabes que se conservan en la Universidad de Granada". XI ${ }^{\text {ème }}$ Congrès International des Orientalistes (Paris, 1897). III. Paris: 45-55.

Almagro Gorbea, Mª .J. (1989): "El Museo Nacional de Reproducciones Artísticas. Necesidad de su reorganización. Objetivos y finalidad". Boletín de la Asociación Nacional de Archiveros, Bibliotecarios, Arqueólogos y Documentalistas, 39 (2): 297-321.

Almagro Gorbea, M. (1999): "El Gabinete de Antigüedades de la Real Academia de la Historia. Pasado, Presente y Futuro". En M. Almagro Gorbea (ed.): El Gabinete de Antigüedades de la Real Academia de la Historia (Madrid, 1998). Real Academia de la Historia. Madrid: 15-173.

Almagro Gorbea, M. (2003): "El Archivo de la Comisión de Antigüedades: una visión de conjunto". En M. Almagro Gorbea y J. Maier (eds.): 250 años de Arqueología y Patrimonio (Madrid, 2002). Real Academia de la Historia. Madrid: 209-224.
Almela Boix, $\mathrm{M}^{\mathrm{a}}$.A. (1991a): "Influencia de la arqueología en la literatura realista española del siglo XIX: algunos cuentos de Don Juan Varela”. En J. Arce y R. Olmos (eds.): Historiografía de la Arqueología y de la Historia Antigua en España (Siglos XVIII-XX) (Madrid, 1988). Ministerio de Cultura. Madrid: 65-68.

Almela Boix, Ma.A. (1991b): “La aportación de José Ramón Mélida a la consolidación de la Arqueología como disciplina en España”. En J. Arce y R. Olmos (eds.): Historiografía de la Arqueología y de la Historia Antigua en España (Siglos XVIII-XX) (Madrid, 1988). Ministerio de Cultura. Madrid: 131-134.

Altamira y Crevea, R. (1901): "Don Juan Facundo Riaño". Revista Crítica de Historia y Literatura españolas, portuguesas e hispano-americanas, abril-mayo 1901 (4-5): 113-116.

Álvarez-Pedrosa Núñez, J.A. (1994): “La lingüística indoeuropea en España hasta 1930". Revista Española de Lingüística, 24 (1): 49-67.

Álvarez Sanchís, J.; Cardito, L.Mª ; Pérez Olmedo, E. y Ortiz de Urbina, C. (2000): Comisión de Antigüedades de la Real Academia de la Historia. Castilla y León. Catálogo e Índices. Real Academia de la Historia. Madrid.

Amador de los Ríos y Fernández de Villalta, R. (1889): Murcia y Albacete. España. Sus monumentos y artes. Su naturaleza é historia. Establecimiento Tipográfico-Editorial de Daniel Cortezo. Barcelona.

Amador de los Ríos y Fernández de Villalta, R. (1875): Inscripciones árabes de Sevilla. Imprenta de Fortanet. Madrid.

Amador de los Ríos y Fernández de Villalta, R. (1879): Inscripciones árabes de Córdoba. Precedidas de un estudio histórico-crítico de la Mezquita Aljama. Imprenta de Fortanet. Madrid.

Amador de los Ríos y Fernández de Villalta, R. (1883): Memoria acerca de algunas inscripciones arábigas de España y Portugal. Imprenta de Fortanet. Madrid.

Artola Gallego, M. (1973): La burguesía revolucionaria (1808-1869). En M. Artola (ed.): Historia de España Alfaguara. V. Alianza Universidad. Madrid.

Asís Aguilar, F. de (1873): El hombre, ¿es hijo del mono? Imprenta de Antonio Pérez Dubrull. Madrid.

Assas y de Ereño, M. de (1839): Diccionario General de Arquitectura. Burgos.

Assas y de Ereño, M. de (1846): “Apuntes sobre el origen y progresos de la Arquitectura”. Boletín Español de Arquitectura, 1: 49-51, 59-60, 78-79, 83-84, 91-92 y 100 . 
Assas y de Ereño, M. de (1848): Álbum artístico de Toledo. Julián Saavedra y Cía. Madrid.

Assas y de Ereño, M. de (1857a): "Nociones fisionómico-históricas de la Arquitectura en España. 1. Monumentos Célticos". Semanario Pintoresco Español, 22: 129-133, 140-142, 148-149, 155-158, $163-165$ y $172-173$.

Assas y de Ereño, M. de (1857b): "Nociones fisionómico-históricas de la Arquitectura en España. 2. Monumentos fenicios". Semanario Pintoresco Español, 22: 177-179.

Assas y de Ereño, M. de (1857c): "Nociones fisionómico-históricas de la Arquitectura en España. 3. Monumentos ciclópeos o pelásgicos". Semanario Pintoresco Español, 22: 193-194 y 196-197.

Assas y de Ereño, M. de (1857d): "Nociones fisionómico-históricas de la Arquitectura en España. 4. Monumentos griegos". Semanario Pintoresco Español, 22: 201-202, 209-210, 217-218, 225-226, 233-234 y 241-243.

Assas y de Ereño, M. de (1857e): "Nociones fisionómico-históricas de la Arquitectura en España. 5. Monumentos cartagineses". Semanario Pintoresco Español, 22: 252-253.

Assas y de Ereño, M. de (1857f): "Nociones fisionómico-históricas de la Arquitectura en España. 6. Monumentos romanos". Semanario Pintoresco Español, 22: 257-259, 265-269, 273-274, 281-283, 289-292, 297-299, 305-306, 313-314, 321-323, $329-330,345-346,353-354,361-363,369-372$, 379-380, 385-387 у 393-394.

Assas y de Ereño, M. de (1876): Programa de la asignatura de Arqueología. Escuela Superior de Diplomática especial del cuerpo facultativo de Archiveros, Bibiotecarios y Anticuarios. Universidad Central. Imprenta de T. Fortanet. Madrid.

Avilés, Á. (1901): “D. Juan F. Riaño”. Nuestro Tiempo. Revista mensual de ciencias y artes, política y hacienda, 1 (4): 652-656.

Ayarzagüena Sánz, M. (1997): “La Sociedad Antropológica Española (SAE) y el nacimiento de la Ciencia Prehistórica en España". En G. Mora y M. Díaz-Andreu (eds.): La cristalización del pasado: génesis y desarrollo del marco institucional de la arqueología en España (Madrid, 1995). Universidad de Málaga-C.S.I.C.-Ministerio de Educación y Cultura. Málaga: 295-301.

Ballesteros Beretta, A. y Ballesteros, P. (1913): Cuestiones históricas (edades antigua y media). III. Establecimiento Tipográfico de J. Pérez Torres. Madrid.

Barberá Martí, F. (1893): “D. Juan Vilanova y Piera. Apunte necrológico". Boletín del Instituto Médico Valenciano, junio 1893, 23: 194-200.
Barnett, R.D. (1998): Sculptures from the Southwest Palace of Sennacherib at Nineveh. British Museum Press. London.

Barros Silvelo, R. (1875): Antigüedades de Galicia. Imprenta Puga. La Coruña.

Beaud, M. (1981/1984): Historia del capitalismo. De 1500 a nuestros días. Ariel. Barcelona.

Belén Deamos, Ma . (2002): "Francisco María Tubino y la arqueología prehistórica en España”. En $\mathrm{M}^{\mathrm{a}}$. Belén y J. Beltrán Fortes (eds.): Arqueología fin de siglo. La arqueología española de la segunda mitad del siglo XIX. I Reunión Andaluza de Historiografía Arqueológica (Sevilla, 1999). Spal Monografías, 3. Universidad de Sevilla. Sevilla: 43-60.

Beltrán Fortes, J. (1997): “Arqueología e Instituciones en la Sevilla del siglo XIX. La Diputación Arqueológica". En G. Mora y M. Díaz-Andreu (eds.): La cristalización del pasado: génesis y desarrollo del marco institucional de la arqueología en España. II Congreso Internacional de Historiografía de la Arqueología en España ( siglos XVIII-XX) (Madrid, 1995). Universidad de MálagaC.S.I.C.-Ministerio de Educación y Cultura. Málaga: 321-329.

Beltrán Fortes, J. (2002): “Arqueología sevillana en la segunda mitad del siglo XIX: una práctica erudita y social". En M. Belén y J. Beltrán Fortes (eds.): Arqueología fin de siglo. La arqueología española de la segunda mitad del siglo XIX. I Reunión Andaluza de Historiografía Arqueológica (Sevilla, 1999). Spal Monografías, 3. Universidad de Sevilla. Sevilla: 11-42.

Beltrán Fortes, J. y Belén, M. (2007): “La Arqueología en la Universidad de Sevilla. I. El siglo XIX". En M. Belén y J. Beltrán Fortes (eds.): Las instituciones en el origen y desarrollo de la arqueología en España. III Reunión Andaluza de Historiografía Arqueológica (Sevilla, 2003). Spal Monografías, 10. Universidad de Sevilla. Sevilla: 94-142.

Beltrán Fortes, J.; Maier, J.; Miranda, J.; Morena, J.A. y Rodríguez Oliva, P. (2010): El Mausoleo de los Pompeyos de Torreparedones (Baena, Córdoba). Antiquaria Hispánica, 17-Salsum, 1. Real Academia de la Historia-Ayuntamiento de Baena. Madrid.

Berlanga Palomo, M M $^{\mathrm{a}}$.J. (2001): "La enseñanza de la arqueología en el siglo XIX: de las cátedras de Castellanos de Losada a la introducción en los estudios universitarios". Anales de Arqueología Cordobesa, 12: 13-33.

Berthelot, S. (1875): "Notice sur des caractères hiéroglyphiques gravés sur des rochers volcaniques aux îles Canaries". Bulletin de la Société de Géographie de Paris, 6e S., 9: 177-192. 
Berthelot, S. (1875/1877): "Noticias sobre los caracteres jeroglíficos grabados en las rocas volcánicas de las Islas Canarias". Boletín de la Sociedad Geográfica de Madrid, 1: 261-279.

Berthelot, S. (1879): Antiquités canariennes ou annotations sur l'origine des peuples qui occupèrent les Iles Fortunées, depuis les premiers temps jusqu'à l'époque de leur conquête. Plon et $\mathrm{C}$. le. Paris.

Berthelot, S. (1879/1980): Antigüedades Canarias. Anotaciones sobre el origen de los pueblos que ocuparon las Islas Afortunadas desde los primeros tiempos hasta la época de su conquista. Goya. Tenerife.

Biosca Mejía, J. (1873): "Consideraciones sobre dos medallones hallados en el Cerro de los Santos, Yecla”. Memorial Numismático Español, 3: 208215.

Bosch Millares, J. (1971): Don Gregorio Chil y Naranjo. Su vida y su obra. Cabildo Insular de Gran Canaria. Las Palmas.

Bosch Millares, J. (1971/2003): Don Gregorio Chil y Naranjo. Su vida y su obra. Colección Viera y Clavijo, 19. El Museo Canario. Las Palmas de Gran Canaria.

Botet y Sisó, J. (1879): Noticia histórica y arqueológica de la antigua ciudad de Emporion. Premiada por la Real Academia de la Historia en el concurso de 1875. Imprenta de Alejandro Gómez Fuentenebro. Madrid.

Boucher de Perthes, J. (1847): Antiquités celtiques et antédiluviennes; mémoire sur l'industrie primitive et les arts à leur origine. Treuttel et Wurtz, Derache. Paris.

Boucher de Perthes, J. (1860): De l'homme antédiluvien et de ses auvres. Jung-Treuttel. Paris.

Broca, P. (1868a): "Description sommaire des restes humains découverts dans les grottes de CroMagnon près de Les Eyzies". Annales de Sciences Naturelles, Zoologie et Paléontologie, 10: 145-155.

Broca, P. (1868b): "Sur les crânes et ossements des Eyzies". Bulletin et Mémoires de la Société d'Anthropologie de Paris, 3: 350-392.

Busk, G. (1869): "On the Caves of Gibraltar in which Human Remains and Works of Art have been found". $3^{\text {rd }}$ International Congress of Prehistoric Archaeology (Norwich-London, 1868). Longmans, Green and Co. London: 106-167.

Cacho Viú, V. (1962/2010): La Institución Libre de Enseñanza. O. Ruiz-Manjón (ed.). Fundación Albéniz-Sociedad Estatal de Conmemoraciones Culturales. Madrid.

Calderón y Arana, S. (1884): "Las antiguas pinturas rojas de España". Actas de la Sociedad Española de Historia Natural, 13: 9-14.
Calle Marín, S. (2004): "La Academia frustrada: la Real de Arqueología y Geografía del Príncipe Alfonso (1837-1868)". En J.L. Gómez Pantoja (ed.): Excavando papeles. Indagaciones arqueológicas en los archivos españoles. Aache Ediciones. Guadalajara: 121-151.

Campaner y Fuertes, A. (1879): Numismática Balear. Descripción histórica de las monedas de las islas Baleares acuñadas durante la dominación púnica, romana, árabe, aragonesa y española. Establecimiento Tipográfico Pedro José Gelabert. Palma de Mallorca.

Campaner y Fuertes, A. (1890): Indicador Manual de la Numismática española. Imprenta de J. Colomar y Salas. Barcelona.

Cánovas del Castillo, A. (1889): “Contestación al discurso de ingreso en la Real Academia de la Historia del doctor Don Juan Vilanova y Piera". En J. Vilanova y Piera, Discursos leídos en la Real Academia de la Historia en la recepción pública del Dr. Don Juan Vilanova y Piera, el día 29 de junio de 1889. Imprenta de A. Pérez Dubrull. Real Academia de la Historia. Madrid: 106-108.

Cartailhac, E. (1886): Les âges préhistoriques de l'Espagne et du Portugal. Résultats d'une mission scientifique du Ministère de l'instruction publique. C. Reinwald. Paris.

Cartailhac, E. (1902): "Les Cavernes ornées de dessins, la grotte d'Altamira (Espagne), 'Mea culpa' d'un sceptique”. L'Anthropologie, 13: 348-354.

Casado Rigalt, D. (2006): José Ramón Mélida (18561933) y la arqueología española. Anticuaria Hispánica, 13. Real Academia de la Historia. Madrid.

Castro y Pajares, F. de (1863): Compendio razonado de Historia General. I. Edad Antigua. Establecimiento tipográfico de Gregorio Estrada. Madrid.

Castro y Pajares, F. de (1866): Compendio razonado

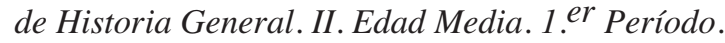
Imprenta de F. Martínez García. Madrid.

Castro y Pajares, F. de (1872): Compendio razonado de Historia General. III. Edad Media. 2. Período. Imprenta de Fermín Martínez García. Madrid.

Castro, F. de y Sales, F. de (1875): Compendio razonado de Historia General. IV. Edad Media. De las Cruzadas hasta fines del siglo XIII. Imprenta de José María Pérez. Madrid.

Chil y Naranjo, G. (1857): Des différentes moyens qui ont eté employés dans le but de guérir les rétrécissements de l'urétre. Thése pour le doctorat en Médecine. Rignoux, imprimeur de la Faculté de Médicine. Paris.

Chil y Naranjo, G. (1875a): "Origine des premiers canariens". III ème Congrès de l'Association 
Française pour l'Avancement des Sciences (Lille, 1874). Secrétariat de l'Association Française pour l'Avancement des Sciences. Paris: 501-506.

Chil y Naranjo, G. (1875b): "La religion des canariens primitifs, et la pierre polie ou néolithique aux Iles Canaries". IVème Congrès de l'Association Française pour l'Avancement des Sciences (Nantes, 1875). Secrétariat de l'Association Française pour l'Avancement des Sciences. Paris: 860-865.

Chil y Naranjo, G. (1876): Estudios históricos, climatológicos y patológicos de las Islas Canarias. Primera Parte. Historia. I. Ernest Leroux éditeurIsidro Miranda Impresor. Paris-Las Palmas.

Chil y Naranjo, G. (1880a): Estudios históricos, climatológicos y patológicos de las Islas Canarias. II. Imprenta de la Atlántida. Las Palmas-Ernest Leroux Libraires-Editeurs. Paris.

Chil y Naranjo, G. (1880b): "Expedición a Guayadeque". El Museo Canario, 1 (5): 129-133, 1 (6): 161-166 у 2 (13): 1-4.

Chinchilla Gómez, M. (1993): "El viaje a Oriente de la fragata Arapiles". en A. Marcos Pous (ed.): De Gabinete a Museo. Tres siglos de historia. Museo Arqueológico Nacional (Madrid, 1993). Museo Arqueológico Nacional-Ministerio de Cultura. Madrid: 286-294.

Coimbra, F.A. Rodrigues (1992-93): "Ricardo Severo e o desenvolvimento da arqueologia no Porto". Portugalia, N.S., 13-14: 307-314.

Cortadella Morral, J. (1997): “La investigación arqueológica en las asociaciones excursionistas catalanas". En G. Mora y M. Díaz-Andreu (eds.): La cristalización del pasado: génesis y desarrollo del marco institucional de la arqueología en España (Madrid, 1995). Universidad de MálagaC.S.I.C.-Ministerio de Educación y Cultura. Málaga: 273-285.

Corte y Ruano, M. de la (1839): “Antigüedades españolas. Descubrimientos de Baena". Semanario Pintoresco Español, 1839: 318-319, 326-328 y 356-358.

Costa, F.A. Pereira da (1865): Da existencia do homem em epochas remotas no valle do Tejo. Noticia sobre os esqueletos humanos descobertos no Cabeço da Arruda. Commissao Geologica de Portugal. Lisboa.

Costa, F.A. Pereira da (1868): "Monuments mégalithiques du Portugal". $2^{\text {me }}$ Congrès International d'Anthropologie et d'Archéologie Préhistoriques (Paris, 1867). C. Reinwald libraire-éditeur. Paris: 180-184

Costa y Martínez, J. (1877): Cuestiones celtibéricas. Religión. Imprenta Costanera del Diario de Huesca. Huesca. 16 p.
Costa y Martínez, J. (1879): “Organización política, civil religiosa de los celtíberos". Revista de España, 67 (2) (268): 490-518 у 67 (3) (269): 63-79.

Costa y Martínez, J. (1881): Introducción a un tratado de política: sacado textualmente de los refraneros, romanceros y gestas de la península. Poesía popular española y mitología y literatura celto-hispanas. Imprenta de la Revista de Legislación. Madrid.

Costa y Martínez, J. (1889): Plan de una Historia del Derecho español en la Antigüedad. Madrid.

Costa y Martínez, J. (1891-95): Estudios ibéricos. I. La servidumbre entre los iberos. II. Litoral ibérico del Mediterráneo en el siglo VI-V antes de J.C. Tipografía de San Francisco de Sales. Madrid.

Costa y Martínez, J. (1901/1967): “Oligarquía y caciquismo como la forma actual de gobierno en España”. Oligarquía y caciquismo, colectivismo agrario y otros escritos. R. Pérez de la Dehesa (ed.). Libro de Bolsillo, 51. Alianza Editorial. Madrid: 15-45.

Costa y Martínez, J. (1917): La religión de los celtíberos y su organización política y civil. Biblioteca Joaquín Costa, 12. Madrid.

Coulanges, F. de (1864): La cité antique. Durand. Paris.

Coulanges, F. de (1875): Histoire des institutions politiques de l'ancienne France. Première partie. L'empire romain, les germains, la royauté mérovingienne. Hachette. Paris.

Cuenca, C.L. de (1901): "D. Juan de Dios de la Rada y Delgado". La Ilustración Española y Americana, 45 (30): 84, 96.

Cueto y Ribero, M. de (1881): "D. Aureliano Fernández-Guerra". La Ilustración Católica, 2a S., 5 (14): 105-107, 5 (15): 114-115 y 5 (16): 122-125.

Darwin, C.R. (1859): On the Origin of Species by Means of Natural Selection, or the Preservation of Favoured Races in the Struggle for Life. John Murray. London.

Darwin, C.R. (1859/1877): El origen de las especies por medio de la selección natural o conservación de las razas en la lucha por la existencia. Trad. Enrique Godínez de la $6^{\mathrm{a}}$ edición inglesa. José de Perojo. Madrid-París.

Darwin, C.R. (1871): The Descent of Man, and Selection in Relation to Sex. John Murray. London.

Darwin, C.R. (1871/1876): El origen del hombre. La selección natural y la sexual. Llop. Imprenta de la Renaixensa. Barcelona.

Delgado y Hernández, A. (1871-73): Nuevo método de clasificación de las medallas autónomas de España. I-II. Imprenta de D. Antonio Izquierdo y García. Sevilla. 
Díaz-Andreu García, M. (1993-94): "La Arqueología en España en los siglos XIX y XX. Una visión de síntesis". O Arqueólogo Português, 4 ${ }^{\mathrm{a}}$ S., 11-12: 189-209.

Díaz-Jiménez y Villamor, J.E. (1922): "La 'Villa' romana de León". Boletín de la Real Academia de Historia, 80 (5): 446-462.

Diccionario Biográfico Español (2010-13). Tomos I-L. Real Academia de la Historia. Madrid.

Duque y Merino, D. (1885): "Nuevas antigüedades recién descubiertas en Juliobriga. Proyecto de un pequeño museo cántabro-juliobrigense". Revista de España, 105 (420): 519-537.

Escribano Martín, F. (2001): "Los estudios sobre Oriente en la España de finales del siglo XIX: la vida y la obra de Francisco García Ayuso”. En J. Córdoba, R. Jiménez Zamudio y C. Sevilla (eds.): El redescubrimiento de Oriente Próximo y Egipto. Viajes, hallazgos e investigaciones (Madrid, 1999). Universidad Autónoma de Madrid. Madrid: 107-116.

Escribano Martín, F. (2005): “Adolfo Rivadeneyra, un diplomático español al servicio del estudio y del viaje por Oriente". En J. Córdoba (ed.): Españoles en Oriente Próximo (1166-1926). Aventureros y peregrinos, militares, científicos y diplomáticos olvidados en el redescubrimiento de un mundo. Arbor, 180 (711-712): 789-804.

Estévez González, F. (1987): Indigenismo, raza y evolución. El pensamiento antropológico canario (1750-1900). Publicaciones científicas del Museo Etnográfico, 4. Cabildo Insular de Tenerife. Tenerife.

Farrujia de la Rosa, A.J. (2004): Ab initio (1342-1969). [Análisis historiográfico y arqueológico del primitivo poblamiento de Canarias]. Artemisa Ediciones. Sevilla-La Laguna.

Farrujia de la Rosa, A.J. (2005): Imperialist archaeology in the Canary Islands. French and German studies on prehistoric colonization at the end of the $19^{\text {th }}$ century. British Archaeological Reports, 1333. Archaeopress. Oxford.

Fernández Chaves, M.F. y Chaves, F. (2004): "Semblanza de un erudito decimonónico y crónica de un olvido. Francisco Mateos Gago y su colección numismática" en F. Chaves y F.J. García Fernández (eds.): Moneta qua scripta. La moneda como soporte de escritura. III Encuentro Peninsular de Numismática Antigua (Osuna, Sevilla, 2003). Anejos de Archivo Español de Arqueología, 33. Consejo Superior de Investigaciones Científicas-Universidad de Sevilla-Fundación El Monte. Sevilla: 313-330.

Fernández de Avilés y Álvarez Ossorio, A. (1948-49): "Las primeras investigaciones del Cerro de los Santos (1860-1870)". Boletín del Seminario de Estudios de Arte y Arqueología, 15 (49-50): 57-70.
Fernández Caro, A. (1889): “El Sr. D. Juan Vilanova y Piera". La Ilustración Española y Americana, 22 de julio, 33 (27): 43-44 y 46.

Fernández-Guerra y Orbe, A. (1834/2010): "Materiales para un opúsculo sobre Las ruinas de Castro-Prisco, y el sepulcro de los Pompeyos". En J. Beltrán Fortes et alii (eds.): El Mausoleo de los Pompeyos de Torreparedones (Baena, Córdoba). Antiquaria Hispánica, 17-Salsum, 1. Real Academia de la Historia-Ayuntamiento de Baena. Madrid: 252-273.

Fernández-Guerra y Orbe, A. (1839/2010): “Impreso de Aureliano Fernández Guerra en el que acusa de plagio a Manuel de la Corte Ruano, Granada, 9 de diciembre de 1839". En J. Beltrán Fortes et alii (eds.): El Mausoleo de los Pompeyos de Torreparedones (Baena, Córdoba). Antiquaria Hispánica, 17-Salsum, 1. Real Academia de la Historia-Ayuntamiento de Baena. Madrid: 308-311.

Fernández-Guerra y Orbe, A. (1840): Ligeros toques al retrato que de sí mismo ha hecho el autor del El más solemne mentís (comedia famosa). Imprenta y Librería de Sanz. Granada.

Fernández-Guerra y Orbe, A. (1852-59): Vida de D. Francisco de Quevedo Villegas, con el examen y juicio crítico de sus 'Discursos políticos satíricos, morales y festivos, ascéticos y filosóficos. I-II. Biblioteca de Autores Españoles, 23. Rivadeneyra. Madrid.

Fernández-Guerra y Orbe, A. (1858): La conjuración de Venecia de 1618, vindicando la memoria del Duque de Osuna y de los marqueses de Vedmar y de Villafranca calumniado de aquel suceso. Discurso leído en la Real Academia de la Historia y contestación de D. José Amador de los Ríos. Madrid.

Fernández-Guerra y Orbe, A. (1860): La canción a las ruinas de Itálica, y original, ya refundida, no es del licenciado Francisco de Rioja, sino del licenciado Rodrigo Caro. Memorias de la Academia Española. Imprenta Nacional. Madrid.

Fernández-Guerra y Orbe, A. (1866a): “Tres sarcófagos cristianos españoles del siglo III, IV y V". Monumentos Arquitectónicos de España. Madrid.

Fernández-Guerra y Orbe, A. (1866b): “Inscripciones cristianas y antiguos monumentos del Arte Cristiano español". El Arte en España, 4: 49-62 y 5: 73-87.

Fernández-Guerra y Orbe, A. (1866c): Munda Pompeyana. Dictamen de D. Aureliano Fernández-Guerra y Orbe. Viaje arqueológico de D. José Oliver y Hurtado. Rivadeyra. Madrid.

Fernández-Guerra y Orbe, A. (1867a): "Trois sarcophages chrétiens des $\mathrm{III}^{\mathrm{e}}, \mathrm{IV}^{\mathrm{e}}$ et $\mathrm{V}^{\mathrm{e}}$ siècles, en Espagne”. Bulletin Monumental, 33: 39-51. 
Fernández-Guerra y Orbe, A. (1867b): "Epigrafía romano-granadina. Carta de D. Aureliano Fernández-Guerra". Revista de Bellas Artes y Arqueología, 31 de agosto, 1 (44): 352-357.

Fernández-Guerra y Orbe, A. (1868): El rey D. Pedro de Castilla. Discurso leído ante la Real Academia de la Historia, en la recepción de D. Javier de Salas. Fortanet. Madrid.

Fernández-Guerra y Orbe, A. (1875a): "Regiones antiguas del Sudeste de España. La contestana ciudad de Ello, cabeza de un distrito ibérico y silla episcopal visigoda. El Heracles elotano, sobre la vía de Hércules llamada después Augusta". Discursos leídos ante la Real Academia de la Historia en la recepción pública de D. Juan de Dios de la Rada y Delgado. Fontanet. Madrid. : 111-179.

Fernández-Guerra y Orbe, A. (1875b): "Sarcófago cristiano de la catedral de Astorga, hoy depositado en el Museo Arqueológico Nacional". Museo Español de Antigüedades, 6: 587-601.

Fernández-Guerra y Orbe, A. (1877): “Una tésera celtíbera. Datos sobre las ciudades celtíberas de Ergávica, Munda, Cértima y Contrebia”. Boletín de la Real Academia de la Historia, 1: 129-139.

Fernández-Guerra y Orbe, A. (1887): "Nuevas inscripciones de Córdoba y Porcuna". Boletín de la Real Academia de la Historia, 11: 168-175.

Fernández-Guerra y Orbe, A. (1901): “Antigüedades romanas de Linares, Cazorla y Baeza". Boletín de la Real Academia de la Historia, 39: 300-306.

Fernández-Guerra y Orbe, A. e Hinojosa, E. (1891): Historia de España desde la invasión de los pueblos germánicos hasta la ruina de la monarquía visigoda. I-II. A. Cánovas del Castillo (ed.): Historia General de España. Real Academia de la Historia. El Progreso Editorial. Madrid.

Fernández-Guerra y Orbe, A. y Menéndez y Pelayo, M. (1897): Obras completas de Don Francisco de Quevedo Villegas. Edición crítica. I. Aparato biográfico y bibliográfico. Sociedad de Bibliófilos andaluces. Imprenta de E. Rasco. Sevilla.

Fernández-Guerra y Orbe, A. y Menéndez y Pelayo, M. (1903): Obras completas de Don Francisco de Quevedo Villegas. Edición crítica. II. Poesías I. Sociedad de Bibliófilos andaluces. Imprenta de E. Rasco. Sevilla.

Fernández-Guerra y Orbe, A. y Menéndez y Pelayo, M. (1907): Obras completas de Don Francisco de Quevedo Villegas. Edición crítica. III. Poesías II. Sociedad de Bibliófilos andaluces. Imprenta de Francisco de P. Díaz. Sevilla.

Fita y Colomé, F. (1882): "Lámina celtibérica de bronce, hallada en el término de Luzaga, partido judicial de Sigüenza". Boletín de la Real Academia de la Historia, 2 (1): 35-44.
Fita y Colomé, F. (1893): "Protohistoria. Conclusiones adoptadas por el Congreso Católico de Sevilla". Boletín de la Real Academia de la Historia, 22 (1): 109-110.

Fita, F. y Fernández-Guerra, A. (1880): Recuerdo de un viaje a Santiago de Galicia. Imprenta de los Sres. Lezcano y Comp. Madrid.

Flores y González, J.Mª (1878): Memoria relativa a las excavaciones de El Castejón en el Concejo de Coaña (Asturias). Oviedo.

Fontana Lázaro, J. (2007): La época del liberalismo. En J. Fontana y R. Villares (eds.): Historia de España. 6. Crítica-Marcial Pons. Barcelona.

Fustel de Coulanges, N.D. (1864): La cité antique. Librairie Hachette. Paris.

Fustel de Coulanges, N.D. (1875): Histoire des institutions politiques de l'ancienne France. Librairie Hachette. Paris

Gallero, V.; Martín Ruiz, J.A. y Pérez-Malumbres, A. (eds.) (2008): Manuel Rodríguez de Berlanga. Liber Amicorvm (1825-1909). Real Academia de Bellas Artes de San Telmo-Ayuntamiento de Alhaurín el Grande. Málaga.

Garay y Anduaga, R. de (1923): “Antigüedades prehistóricas de la provincia de Huelva. Primera comunicación, fecha 10 de febrero de 1870. Segunda comunicación, de fecha 4 de octubre de 1870". Boletín de la Real Academia de la Historia, 83 (1): 35-48.

García Álvarez, R. (1872): Discurso leído en la solemne apertura del curso académico de 1872 a 1873 en el Instituto de Segunda Enseñanza de Granada. Imprenta de Indalecio Ventura Sabatel. Granada.

García Álvarez, R. (1883): Estudio sobre el Transformismo. Imprenta de Ventura Sabatel. Granada.

García Ayuso, F. (1871): El estudio de la filología en su relación con el sánskrito. Imprenta de Rivadeneyra. Madrid.

García Ayuso, F. (1871/1884): L'étude de la philologie dans ses rapports avec le sanskrit. Budin. Angers.

García Ayuso, F. (1874): Los pueblos iranios y Zoroastro. Noguera. Madrid.

García Ayuso, F. (1877): Ensayo crítico de Gramática comparada de los idiomas indo-europeos, Sanskrit, Zend, Latín, Griego, Antiguo Eslavo, Litauico, Godo, Antiguo Alemán y Armenio. Capellanes. Madrid.

García Ayuso, F. (1881): "Los congresos de Orientalistas de Berlín”. Revista de España, 81 (322): 162-175 y 81 (327): 367-380.

García Ayuso, F. (1894): Estudio comparativo sobre el origen y formación de las lenguas neosanskritas y neolatinas. Discursos leídos ante la Real Academia 
Española en la recepción pública del señor D. Francisco García Ayuso, el 6 de mayo de 1894. Madrid.

García Ayuso, F. (1897): Las oposiciones de sánskrito por varios aficionados al estudio del sánskrito. Rectificación y réplica. Calumnia, que algo queda. Sucesores de Rivedeneyra. Madrid.

García y López, J.C. (1870): Catálogo de la biblioteca de la Sociedad Económica Matritense. Sociedad Económica Matritense. Madrid.

García y López, J.C. (1872): El municipio durante la monarquía visigoda. Madrid.

García y López, J.C. (1877): Datos bibliográficos sobre la Sociedad Económica Matritense. Imprenta y Fundición de M. Tello. Madrid.

García y López, J.C. (1878a): "La edad de piedra. Al excelentísimo señor Marqués de Cerralbo". La Ilustración Católica, 2 (3): 18-20, 2 (4): 27-30, 2 (5): 35-38, 2 (6): 42-43, 2 (7): 50-52 y 2 (9): 67-70.

García y López, J.C. (1878b): La edad de piedra. Imprenta de la Ilustración Católica. Madrid.

García y López, J.C. (1879): El hombre terciario. Discurso leído en la Juventud Católica de Madrid en la apertura de curso 1879-80, por su presidente don Juan Catalina García y López. Imprenta F. Maroto e Hijos. Madrid.

García y López, J.C. (1891-93): Castilla y León durante los reinados de Pedro I, Enrique II, Juan I y Enrique III. I-II. III (32 pp.). El Progreso Editorial. Madrid.

García y López, J.C. [y Rada y Delgado, J. de D. de la] (1903): Inventario de las antigüedades y objetos de arte que posee la Real Academia de la Historia. Boletín de la Real Academia de la Historia, 42 (4): 311-316, 42 (5): 321-368, 42 (6): 484-505 y 43 (4): 257-322. Real Academia de la Historia. Imprenta Fortanet. Madrid.

García Rueda Muñoz de San Pedro (1997): "La Sociedad Española de Excursiones. Sus primeros pasos para divulgar la Arqueología". En G. Mora y M. Díaz-Andreu (eds.): La cristalización del pasado: génesis y desarrollo del marco institucional de la arqueología en España (Madrid, 1995). Universidad de Málaga-C.S.I.C.-Ministerio de Educación y Cultura. Málaga: 287-293.

Gelabert y Gordiola, J. (1890): Manual de lengua sanscrita. Crestomatía y gramática. Madrid-Bonn.

Gestoso y Pérez, J. (1889): Necrología del Excmo. Señor D. Francisco María Tubino, escrita y publicada en cumplimiento de acuerdo de la Real Academia Sevillana de Buenas Letras. Tipografía de La Andalucía. Sevilla.

Giner de los Ríos, F. (1901): "Riaño y la Institución libre". Boletín de la Institución Libre de Enseñanza, 25 (494): 129-131.
Glick, T.F. (1982): Darwin en España. Ediciones Península. Barcelona.

Goberna Valencia, M ${ }^{\mathrm{a}}$.V. (1981): "La Sociedad Arqueológica Valenciana". Archivo de Prehistoria Levantina, 16: 575-605.

Gómez Pérez, J. (1958): “Castellanos de Losada y la Real Academia de Arqueología y Geografía". Revista de Archivos, Bibliotecas y Museos, 65: 561-567.

Góngora y Martínez, M. de (1868): Antigüedades prehistóricas de Andalucía. Monumentos, inscripciones, armas, utensilios y otros importantes objetos pertenecientes a los tiempos más remotos de su población. Imprenta C. Moro. Madrid.

González Alonso, E. (1997): "Lancia. Fuentes e Historiografía”. Lancia, 2: 181-206.

González de Linares, A. (1873): Ensayo de una introducción al estudio de la Historia Natural. Imprenta de M. Rivadeneyra. Madrid.

González Hurtebise, E. (1895): Apuntes de Numismática tomados de las explicaciones del catedrático de la asignatura D. Juan de Dios de la Rada y Delgado. Madrid.

González Ruibal, A. (2000): Comisión de Antigüedades de la Real Academia de la Historia. Galicia. Catálogo e Índices. Real Academia de la Historia. Madrid.

Gran-Aymerich, E. y Gran-Aymerich, J. (1991): “Les échanges franco-espagnols et la mise en place des institutions archéologiques (1830-1939)". En J. Arce y R. Olmos (eds.): Historiografía de la Arqueología y de la Historia Antigua en España (Siglos XVIII-XX) (Madrid, 1988). Ministerio de Cultura. Madrid: 117-124.

Guillén Robles, F. (1881): “Rapport sur l'état actuel des études arabes en Espagne". Verhandlungen des Fünften Internationalen Orientalisten-Congresses. Gehalten zu Berlin im september 1881. I. Berlin: 56-57.

Haeckel, E. (1876): “Origen y genealogía de la raza humana". Revista Mensual de Filosofía, Literatura y Ciencias, 6: 26.

Haeckel, E. (1878-79): Historia de la creación natural o doctrina científica de la evolución. I-II. Tipografía de J.C. Conde y Cía. Madrid.

Haeckel, E. (1886): La evolución y el transformismo. Imprenta Rollo. Madrid.

Harlé, E. (1881): "La grotte d'Altamira, près de Santander (Espagne)". Matériaux pour l'histoire primitive et naturelle de l'homme, $2^{\mathrm{a}}$ S., 12: 275-283.

Heiss, A. (1870): Description générale des monnaies antiques de l'Espagne. Imprimerie Nationale. Paris. 
Hernández Pacheco, E. (1911): "El profesor Don Salvador Calderón y Arana y su labor científica". Boletín de la Institución Libre de Enseñanza, 31 de diciembre, 35 (621): 353-365.

Hübner, E. (1871): Inscriptiones Hispaniae Christianae. Georgium Reimerum. Berolini-Berlin.

Hübner, E. (1876): "Reseña de J. de D. de la Rada y Delgado, Antigüedades del Cerro de los Santos en término de Montealegre, Madrid, 1875". Jenaer Literaturzeitung, 1876: 217.

Hübner, E. (1888): La arqueología de España. Tipografía-Litografía de los Sucesores de Ramírez y $\mathrm{C}^{\mathrm{a}}$. Barcelona.

Hübner, E. (1895): “Estudios ibéricos, por Joaquín Costa”. Revista Crítica de Historia y Literatura Española, marzo 1895, 1: 3.

Hübner, E. (1897): "Los trabajos científicos del Excmo. Sr. D. Jacobo Zóbel de Zangroniz, académico electo (1842-1896)". Boletín de la Real Academia de la Historia, 30 (2): 158-181.

Hübner, E. (1900): Inscriptionum Hispaniae Christianarum supplementum. Georgii Reimeri. Berolini-Berlin.

Huici Goñi, M ${ }^{\mathrm{a}}$.P. (1990): "Las Comisiones de Monumentos Históricos y Artísticos con especial referencia a la Comisión de Navarra". Príncipe de Viana, 51 (189): 119-209.

Ibarra y Manzoni, A. (1879): Illici, su situación y antigüedades. Establecimiento Tipográfico de Antonio Reus. Alicante.

Inchaurrandieta y Páez, R. de (1870a): "Estudios prehistóricos. La Edad del Bronce en la provincia de Murcia”. Revista de la Universidad de Madrid, 2 (13): 806-813.

Inchaurrandieta y Páez, R. de (1870b): "Relación de los objetos procedentes del Cerro de la Bastida, que existen en el Museo de la Escuela Especial de Ingenieros de Caminos". Revista de la Universidad de Madrid, 2 (13): 813-815.

Inchaurrandieta y Páez, R. de (1875): "Notice sur la montagne funéraire de La Bastida, province de Murcia". $\quad 4^{\grave{e ̀ m e}}$ Congrès International d'Anthropologie et d'Archéologie Préhistoriques (Copenhague, 1869). Imprimerie de Thiele. Copenhague: 344-350.

Iturralde y Suit, J. (1911): “Obras completas de D. Juan Iturralde y Suit. II. La Prehistoria en Navarra. Imprenta y Librería de J. García. Pamplona.

Jacques, V. (1891): "Les races préhistoriques de

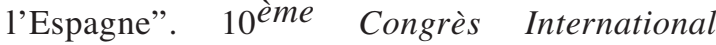
d'Anthropologie et d'Archéologie Préhistoriques (Paris, 1889). Ernest Leroux, éditeur. Paris: 451455.
Jiménez Díez, J.A. y Mederos, A. (2001): Comisión de Antigüedades de la Real Academia de la Historia. Baleares. Canarias. Melilla. Gibraltar. Extranjero. Catálogo e Índices. Real Academia de la Historia. Madrid.

Labra y Cadrana, R.M ${ }^{\mathrm{a}}$. de (1906): El Ateneo de Madrid, 1835-1905. Notas históricas. Tipografía de Alfredo Alonso. Madrid.

Lara Escoz, J.I. (2007): "La Comisión de Monumentos Históricos y Artísticos de Sevilla en el siglo XIX. Una perspectiva arqueológica". En M. Belén y J. Beltrán Fortes (eds.): Las instituciones en el origen y desarrollo de la arqueología en España. III Reunión Andaluza de Historiografía Arqueológica (Sevilla, 2003). Spal Monografías, 10. Universidad de Sevilla. Sevilla: 67-92.

Lasalde Lombela, C. (1871): "Primeros pobladores de España”. La Ilustración de Madrid, Revista de política, ciencias, artes y literatura, 15 de marzo de 1871, 2 (29): 67-69 y 30 de marzo de 1871, 2 (30): 91-94.

Lasalde Lombela, C. (1880-81): "Las antigüedades de Yecla". La Ciencia Cristiana, 16: 465-471 y 567571 y 17: 166-176.

Lasalde, C. y Sáez del Caño, T. (1871): Memoria sobre las Notables Escavaciones Hechas en el Cerro de los Santos. Publicada por los PP. Escolapios de Yecla. Imprenta de J. Limia y G. Vrosa. Madrid.

Lavín Berdonces, A.C. (1997): "La labor arqueológica de la Comisión de Monumentos de Navarra". Príncipe de Viana, 58 (211): 403-444.

Letamendi y Manjarrés, J. (1867): Discurso sobre la naturaleza y el origen del hombre. Pronunciado en el Ateneo catalán, (Sección de Ciencias exactas, físicas y naturales), en las noches del 13 y 14 de abril de 1867. Establecimiento Tipográfico de Narciso Ramírez y Compañía. Barcelona.

Liñán y Eguizábal, J.P., Conde de Doña Marina (1911): "Don Juan Catalina García". Revista de Archivos, Bibliotecas y Museos, $3^{\mathrm{a}}$ S., 15 (1-2): 177-186.

López Azorín, F. y Ruiz Molina, L. (2000): "El Padre Lasalde y la colección ibérica del Museo de Yecla (1873-1900)". En J. Blánquez y L. Roldán (eds.): La Cultura ibérica a través de la fotografía de principios de siglo. El litoral mediterráneo (Alcalá de Henares, 2000). Caja de Ahorros del Mediterráneo-Universidad Autónoma de Madrid. Madrid: 39-50.

López Cidad, F. y Tostón, F. (2004): “José Villa-Amil y Castro". En M. Ayarzagüena y G. Mora (eds.): Pioneros de la Arqueología en España del siglo XVI a 1912. Zona Arqueológica, 3: 107-112.

López García, B. (1990): “Arabismo y orientalismo en España: radiografía y diagnóstico de un gremio 
escaso y apartadizo". En V. Morales Lezcano (ed.): Africanismo y Orientalismo en España (18601930). Africanismo y Orientalismo en España (1860-1930) Awraq, 11 (anejo): 35-69.

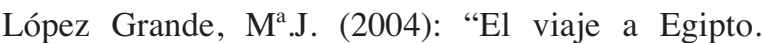
Primeros viajeros españoles y primeras miradas de la investigación española hacia las tierras del Nilo". Cuadernos de Prehistoria y Arqueología de la Universidad Autónoma de Madrid, 30: 225-239.

López Trujillo, M.A. y García-Risco, M.C. (1996): "La Comisión de Monumentos de Guadalajara. Breve reseña histórica e inventario de sus fuentes (1835-1939)". La investigación y las fuentes documentales de los archivos. Guadalajara: 443-456.

Lubbock, J., Barón de Avebury (1865): Prehistoric Times, as illustrated by Ancient Remains, and the Manners and Customs of Modern Savages. Williams and Norgate. London.

Luzón Nogué, J.Ma . (1993): "La Real Academia de Arqueología y Geografía del Príncipe Alfonso". A. Marcos Pous (ed.): De Gabinete a Museo. Tres siglos de historia. Museo Arqueológico Nacional (Madrid, 1993). Museo Arqueológico NacionalMinisterio de Cultura. Madrid: 271-275.

Luzón Nogué, J.Mª (1999): Sevilla la Vieja. Un paseo histórico por las ruinas de Itálica. Fundación Focus-Abengoa. Sevilla.

MacPherson y Hermás, G. (1870-71): La Cueva de la Muger. Descripción de una caverna conteniendo restos prehistóricos descubierta en las inmediaciones de Alhama de Granada. Primera y segunda parte. Imprenta de la Revista Médica, de D. Federico Joly. Cádiz.

Machado y Núñez, A. (1871): “Apuntes sobre la teoría de Darwin". Revista Mensual de Filosofía, Literatura y Ciencias, 3: 461-470.

Machado y Núñez, A. (1872a): “Teoría de Darwin. Combate por la existencia". Revista Mensual de Filosofía, Literatura y Ciencias, 4 : 3 y 129-133.

Machado y Núñez, A. (1872b): "Darwinismo". Revista Mensual de Filosofía, Literatura y Ciencias, 4: $523-524$ y 528.

Madariaga de la Campa, B. (1976): Marcelino Sanz de Sautuola. Escritos y Documentos. Institución Cultural de Cantabria de la Diputación Provincial. Santander.

Madariaga de la Campa, B. (2004): Marcelino Sanz de Sautuola y la Cueva de Altamira. Instituto para Investigaciones Prehistóricas de Santander. Santander.

Maier Allende, J. (1997): "Las sociedades arqueológicas en España: la Sociedad Arqueológica de Carmona". En G. Mora y M. Díaz-Andreu (eds.), La cristalización del pasado: génesis y desarrollo del marco institucional de la arqueología en España (Madrid, 1995). Universidad de MálagaC.S.I.C.-Ministerio de Educación y Cultura. Málaga: 303-319.

Maier Allende, J. (1998): Comisión de Antigüedades de la Real Academia de la Historia. Madrid. Catálogo e Índices. Real Academia de la Historia. Madrid.

Maier Allende, J. (1999a): Jorge Bonsor (1855-1930). Un Académico Correspondiente de la Real Academia de la Historia y la Arqueología Española. Real Academia de la Historia. Madrid.

Maier Allende, J. (1999b): Epistolario de Jorge Bonsor (1886-1930). Gabinete de Antigüedades, Estudios 6. Real Academia de la Historia. Madrid.

Maier Allende, J. (1999c): Comisión de Antigüedades de la Real Academia de la Historia. Castilla-La Mancha. Catálogo e Índices. Real Academia de la Historia. Madrid.

Maier Allende, J. (2003): "La Comisión de Antigüedades de la Real Academia de la Historia". En M. Almagro Gorbea y J. Maier (eds.): 250 años de Arqueología y Patrimonio. (Madrid, 2002) Real Academia de la Historia. Madrid: 27-51.

Maier Allende, J. (2007): “Aureliano FernándezGuerra, Giovanni Battista de Rossi y la Arqueología Paleocristiana en la segunda mitad del siglo XIX". En J. Beltrán, B. Cacciotti y B. Palma Venetucci (eds.): Arqueología, coleccionismo y Antigüedad. España e Italia en el siglo XIX (Sevilla, 2004). Universidad de Sevilla. Sevilla: 299-350.

Maier Allende, J. (2008): Noticias de Antigüedades de las Actas de Sesiones de la Real Academia de la Historia (1834-1874). Real Academia de la Historia. Madrid.

Maier, J. y Salas, J. (2007): "Los Inspectores de Antigüedades de la Real Academia de la Historia en Andalucía”. En M. Belén y J. Beltrán Fortes (eds.): Las instituciones en el origen y desarrollo de la arqueología en España. III Reunión Andaluza de Historiografía Arqueológica (Sevilla, 2003). Spal Monografías, 10. Universidad de Sevilla. Sevilla: 175-238.

Maier, J.; Salas, J.; Berlanga, Ma .J. y Bellón, J.P. (2000): Comisión de Antigüedades de la Real Academia de la Historia. Andalucía. Catálogo e Índices. Real Academia de la Historia. Madrid.

Manso Porto, C. (2008-09): "La colección de dibujos lucenses de José Villaamil y Castro conservados en la Real Academia de la Historia". Abrente, 40-41: 245-304.

Marcos Pous, A. (1993): "Origen y desarrollo del Museo Arqueológico Nacional". En A. Marcos Pous (ed.): De Gabinete a Museo. Tres siglos de 
historia. Museo Arqueológico Nacional (Madrid, 1993). Museo Arqueológico Nacional-Ministerio de Cultura. Madrid: 21-99.

Martínez Cuadrado, M. (1973): Restauración y crisis de la monarquía (1874-1931). En M. Artola (ed.): Historia de España Alfaguara. VI. Alianza Universidad. Madrid.

Martorell y Peña, F. (1879): Apuntes Arqueológicos. S. Sampere (ed.). V. Dona. Barcelona.

Mateu y Llopis, F. (1949): “Cartas numismáticas de don Jacobo Zóbel de Zangróniz a don Álvaro Campaner y Fuertes (1862-1881). Seleccionadas y anotadas". Boletín de la Real Academia de la Historia, 125 (1): 87-159.

Mederos Martín, A. (1997): “Trayectorias divergentes de las dos principales instituciones museísticas canarias". En G. Mora y M. Díaz-Andreu (eds.): La cristalización del pasado: génesis y desarrollo del marco institucional de la arqueología en España (Madrid, 1995). Universidad de Málaga-C.S.I.C.-Ministerio de Educación y Cultura. Málaga: 391-400.

Mederos Martín, A. (2003): "Islas Canarias". En M. Almagro Gorbea y J. Maier (eds.): 250 años de Arqueología y Patrimonio (Madrid, 2002). Real Academia de la Historia. Madrid: 195-207.

Mélida y Alinari, J.R. (1881): “Colección de antigüedades egipcias que se conserva en el Museo Arqueológico Nacional". Revista de España, 13 de enero de 1881, 78: 93-105.

Mélida y Alinari, J.R. (1882): “Sobre los vasos griegos, etruscos e italo-griegos del Museo Arqueológico Nacional". La Ilustración Española y Americana, 22 de agosto, 26 (31): 102-103 y 106.

Mélida y Alinari, J.R. (1883): "Las antigüedades de la Exposición de Minería". Revista de Archivos, Bibliotecas y Museos, $2^{\text {a }}$ S., 9: 354-358 y 386-398.

Mélida y Alinari, J.R. (1884a): Sobre las esculturas de barro cocido, griegas, etruscas y romanas del M.A.N. Sucesores de Rivadeneyra. Madrid.

Mélida y Alinari, J.R. (1884b): La Religión Egipcia. Conferencia leída en el Ateneo de Madrid el 6 de mayo de 1884. Tipografía de El Correo. Madrid.

Mélida y Alinari, J.R. (1900): "La colección de bronces antiguos de D. Antonio Vives". Revista de Archivos, Bibliotecas y Museos, $3^{\text {a }}$ S., 4 (1): 27-30, 4 (2): 70-76, 4 (3) 154-164, 4 (6): 351-354, 4 (7): $404-410,4$ (8-9): 541-546, 4 (11): 624-627 у 4 (12): 649-651.

Mélida y Alinari, J.R. (1903a): "Las esculturas del Cerro de los Santos: cuestión de autenticidad". Revista de Archivos, Bibliotecas y Museos, $3^{\text {a }}$ S., 7 (2): $85-90$ y 7 (6): 470-485.

Mélida y Alinari, J.R. (1903b): "Las esculturas del Cerro de los Santos: cuestión de autenticidad".
Revista de Archivos, Bibliotecas y Museos, $3^{\text {a }}$ S., 9 (8-9): 140-148, 9 (10): 247-255 у 9 (12): 365-372.

Menéndez y Pelayo, M. (1881/1967): Historia de los Heterodoxos Españoles. I-II. Biblioteca de Autores Cristianos. Madrid.

Menéndez y Pelayo, M. (1982-91/1999): Epistolario. I-XXIII. Fundación Universitaria Española. Madrid. Cd-rom. Caja Cantabria. Santander.

Merino Santisteban, J. (1997): “Arqueología y conservación del Patrimonio Histórico en la Mallorca de la Restauración”. En G. Mora y M. Díaz-Andreu (eds.): La cristalización del pasado: génesis y desarrollo del marco institucional de la arqueología en España (Madrid, 1995). Universidad de Málaga-C.S.I.C.-Ministerio de Educación y Cultura. Málaga: 369-379.

Miranda Valdés, J. (2005): Aureliano FernándezGuerra y Orbe (1816-1894). Un romántico, escritor y anticuario. Anticuaria Hispánica, 10. Real Academia de la Historia. Madrid.

Miranda, J.; Gimeno, H. y Sánchez Medina, E. (2011): Emil Hübner, Aureliano Fernández-Guerra y la Epigrafía de Hispania. Correspondencia 18601894. Antiquaria Hispánica, 22. Real Academia de la Historia-Universidad de Alcalá. Madrid.

Molinero Polo, M.A. (2004): “El pozo y el péndulo. La actividad egiptológica de anticuarios y arqueólogos españoles, 1868-1966". En A. Martín Flores y $\mathrm{M}^{\mathrm{a}}$.V. López Hervás (eds.): Españoles en el Nilo. I. Misiones Arqueológicas en Egipto. Museo de San Isidro. Madrid: 15-62.

Molinero Polo, M.A. (2011): "La creación frustrada de cátedras de lenguas orientales (egipcio antiguo, asirio y chino) en la Universidad Central". Gerión, 29 (2): 15-33.

Mora Rodríguez, G.; Tortosa, T. y Gómez Gómez, Ma.A. (2001): Comisión de Antigüedades de la Real Academia de la Historia. Valencia. Murcia. Catálogo e Índices. Real Academia de la Historia. Madrid.

Mora Serrano, B. y Volk, T. (2002): "La numismática en Andalucía en la segunda mitad del siglo XIX". En $\mathbf{M}^{\mathrm{a}}$. Belén y J. Beltrán Fortes (eds.): Arqueología fin de siglo. La arqueología española de la segunda mitad del siglo XIX. I Reunión Andaluza de Historiografía Arqueológica (Sevilla, 1999). Spal Monografías, 3. Universidad de Sevilla. Sevilla: 179-204.

Moreno Tovillas, S. (1872/1942): Apuntes sobre las estaciones prehistóricas de la sierra de Orihuela. Trabajos Varios del Servicio de Investigación Prehistórica, 7. Valencia.

Mortillet, G. de (1883): Le Préhistorique. Antiquité de l’homme. C. Reinwald Libraire-Éditeur. Paris. 
Navarro Pérez, E.J. (1884): Estudio prehistórico sobre la Cueva del Tesoro. Sociedad Malagueña de Ciencias Físicas y Naturales. Tipografía de la Biblioteca Andaluza. Málaga.

Núñez Encabo, M. (1976): Manuel Sales y Ferré: los orígenes de la Sociología en España. Editorial Cuadernos para el Diálogo-Edicusa. Madrid.

Núnez Ruiz, D. (1977): El darwinismo en España. Castalia. Madrid.

Oliver y Hurtado, J. y Oliver y Hurtado, M. (1875): Granada y sus monumentos árabes. Imprenta de M. Oliver Navarro. Málaga.

Olmedo Checa, M. (1985): “Manuel Rodríguez de Berlanga: un hombre singular en la Málaga del XIX”. Jábega , 49: 71-80.

Olmedo Checa, M. (2000): "Introducción”. En M. Rodríguez de Berlanga, Monumentos Históricos del Municipio Flavio Malacitano. Diputación Provincial de Málaga. Málaga: 9-129.

Padró i Parcerisa, J. (1988): "Eduard Toda, diplomate espagnol, érudit catalan et égyptologue du XIX $\mathrm{X}^{\mathrm{e}}$ siècle". Bulletin de la Société Française d'Egyptologie, 113: 32-45.

Papí Rodes, C. (2004): "Juan de Dios de la Rada y Delgado". En M. Ayarzagüena y G. Mora (eds.): Pioneros de la Arqueología en España del siglo XVI a 1912. Zona Arqueológica, 3: 253-260.

Paris, P. (1908): "Proménades Archéologiques en Espagne". Bulletin Hispanique, 10: 7-13.

Paris, P. (1910): Proménades archéologiques en Espagne. E. Leroux. Paris.

Pasamar, G. y Peiró, I. (2002): Diccionario Akal de Historiadores españoles contemporáneos (18401980). Akal. Madrid.

Pascual González, J. (2001): “Las jornadas en Siria y Palestina de Juan de Dios de la Rada y la expedición de la fragata de guerra Arapiles". En J. Córdoba, R. Jiménez Zamudio y C. Sevilla (eds.): El redescubrimiento de Oriente Próximo y Egipto. Viajes, hallazgos e investigaciones (Madrid, 1999). Universidad Autónoma de Madrid. Madrid: 31-50.

Pascual González, J. (2005): "Don Juan de Dios de la Rada y Delgado y los expedicionarios de la fragata de guerra Arapiles en Tierra Santa”. En J. Córdoba (ed.): Españoles en Oriente Próximo (1166-1926). Aventureros y peregrinos, militares, científicos y diplomáticos olvidados en el redescubrimiento de un mundo. Arbor, 180 (711-712): 805-824.

Pégot-Ogier, E. (1869): Les iles Fortunées ou Archipel des Canaries. Librairie Internationale-A. LacroixVerboechkhoven et Cie. Editeurs. Paris-BruxellesLeipzig.

Pégot-Ogier, E. (1869/2009): Las Islas Afortunadas o Archipiélago de las Canarias. I-II. J.J. Vega (ed.). Cabildo de Gran Canaria. Madrid-Las Palmas.
Peiró Martín, I. (1995/2006): Los guardianes de la historia. La historiografía académica de la Restauración. $2^{\mathrm{a}}$ edición revisada y aumentada. Institución Fernando el Católico. Zaragoza.

Peiró Martín, I. (1996): “Los historiadores oficiales de la Restauración (1874-1910)". Boletín de la Real Academia de la Historia, 193 (1): 13-72.

Peiró, I. y Pasamar, G. (1996): La Escuela Superior de Diplomática (los archiveros en los historiografía española contemporánea). Asociación Española de Archiveros, Bibliotecarios, Museólogos y Documentalistas. Madrid.

Pelayo López, F. (1995): “Un capítulo en la creación de la cátedra de Geología y Paleontología de la Universidad Central: la formación científica de Juan Vilanova en Europa”. Llull, 18: 494-516.

Pelayo, F. y Gozalo, R. (2012): Juan Vilanova y Piera (1821-1893), la obra de un naturalista y prehistoriador valenciano. La donación Masiá Vilanova en el Museo de Prehistoria de Valencia. Trabajos Varios del Servicio de Investigación Prehistórica, 114. Diputación de Valencia. Valencia.

Peña y Fernández, M. de la (1890): Manual de Arqueología Prehistórica: precedido de nociones preliminares de arqueología general, geología y paleontología; y seguido de cinco cuadros sinópticos de arquitectura cristiana y de vocabularios para la debida inteligencia de las voces técnicas. Tipografía de los Sres. A. Izquierdo y Sobo. Sevilla.

Peñuela, J.A. (1966): “Tres restos de lápida asirios en la Real Academia de la Historia”. Sefarad, 26 (2): 247-252.

Pérez-Accino, J.R. (2001): “Se mecieron en la misma cuna'. Egipto en el descubrimiento de la cultura ibérica". En J. Córdoba, R. Jiménez Zamudio y C. Sevilla (eds.): El redescubrimiento de Oriente Próximo y Egipto. Viajes, hallazgos e investigaciones (Madrid, 1999). Universidad Autónoma de Madrid. Madrid: 251-262.

Pérez de la Dehesa, R. (1967): "Prólogo". Joaquín Costa, Oligarquía y caciquismo, colectivismo agrario y otros escritos. R. Pérez de la Dehesa (ed.). Libro de Bolsillo, 51. Alianza Editorial. Madrid: 7-14.

Pérez-Villamil García-Somolinos, M. (1911): "Don Juan Catalina García y López". Boletín de la Real Academia de Historia, 58 (2): 149-154.

Pericot García, L. (1964): Medio siglo de Prehistoria hispánica. Discurso inaugural del año académico 1964-1965. Universidad de Barcelona. Barcelona.

Peset, J.L. (1988): “El Real Consejo de Instrucción Pública y la Restauración canovista". Hispania, 48 (170): 989-1030. 
Prado y Vallo, C. de (1863): "Sobre la adopción de voces nuevas en la geología”. Revista Minera, 14: 3-9.

Prado y Vallo, C. de (1864): Descripción física y geológica de la provincia de Madrid. Imprenta Nacional. Madrid.

Puelles Benítez, M. de (1980/1991): Educación e ideología en la España contemporánea. Colección Labor, 7. Labor. Barcelona.

Pujol y Camps, C. (1878): Estudio de las monedas de Empuries y Rhode con sus imitaciones. Imprenta de José María Ariza. Sevilla.

Quatrefages de Breu, J.L.A. de (1870): Darwin et ses précurseurs français. Félix Alcan. Paris.

Quatrefages de Breu, J.L.A. de (1874): Historia Natural del hombre (Vincennes, 1868). M. Sales y Ferré (ed.). Madrid.

Quatrefages, J.L.A. de y Hamy, E. (1874): "La race de Cro-Magnon dans l'espace et dans le temps". Bulletin et Mémoires de la Société d'Anthropologie de Paris, 9: 260-266.

Quintana, M.J. (1877): Siria y Líbano. Imprenta de Manuel G. Hernández. Madrid.

Quintero y Atauri, P. (1914): "Necrópolis ante-romana de Cádiz”. Boletín de la Sociedad Española de Excursiones, 22 (2): 81-107 y 22 (3): 161-175.

Quiroga Rodríguez, F. (1893): “El Profesor D. Juan Vilanova y Piera". Actas de la Sociedad Española de Historia Natural, 22: 132-137.

Quiroga, F. y Torres Campos, R. (1880): "La cueva de Altamira". Boletín de la Institución Libre de Enseñanza, 16 de noviembre, 90: 161-163.

Rada y Delgado, J. de D. de la (1858): "Momias egipcias". El Museo Universal, 2 (12): 92-95, 2 (13): 101-103 y 2 (14): 110-111.

Rada y Delgado, J. de D. de la (1860): “Arquitectura egipcia”. El Museo Universal, 4 (2): 11-13.

Rada y Delgado, J. de D. de la (1863): "Estudios arqueológicos. Situación de la antigua illiberis". El Museo Universal, 7 (25): 194-195, 7 (28): 219-220 y 7 (29): 230-231.

Rada y Delgado, J. de D. de la (1875a): Antigüedades del Cerro de los Santos en término de Montealegre. Discursos leídos ante la Real Academia de la Historia en la recepción pública de D. Juan de Dios de la Rada y Delgado. Fontanet. Madrid.

Rada y Delgado, J. de D. de la (1875b): “Antigüedades del Cerro de los Santos en término de Montealegre, conocidas vulgarmente bajo la denominación de "Antigüedades de Yecla"'. Museo Español de Antigüedades, 6: 249-290.

Rada y Delgado, J. de D. de la (1876a): "Esculturas chipriotas traídas al Museo Arqueológico Nacional por la Comisión Arqueológica de Oriente". Museo Español de Antigüedades, 7: 685-692.

Rada y Delgado, J. de D. de la (1876b): "Esculturas procedentes del Cerro de los Santos, en término de Montealegre, nuevamente adquiridas por el Museo Arqueológico Nacional”. Museo Español de Antigüedades, 7: 595-599.

Rada y Delgado, J. de D. de la (1876-82): Viaje a Oriente de la fragata de guerra Arapiles y de la Comisión científica que llevó a su bordo. I-III. Emilio Oliver y Compañía, Editores. Barcelona.

Rada y Delgado, J. de D. de la (1880): "Vasos chipriotas que se conservan en el Museo Arqueológico Nacional, traídos a España por la Comisión de Oriente en 1871". Museo Español de Antigüedades, 10: 441-482.

Rada y Delgado, J. de D. de la (1885): La Necrópolis de Carmona. Memoria escrita en virtud de acuerdo de las Reales Academias de la Historia y de Bellas Artes de San Fernando. Manuel Tello. Madrid.

Rada y Delgado, J. de D. de la (1894a): Discursos leídos ante la Real Academia de la Historia en la recepción pública del Excmo. Señor D. Juan Catalina García en 27 de mayo de 1894. Contestación del Excelentísimo Señor D. Juan de Dios de la Rada y Delgado. El Progreso Editorial. Madrid: 139-154.

Rada y Delgado, J. de D. de la (1894b): "Aureliano Fernández-Guerra y Orbe”. La Ilustración Española y Americana, 15 de septiembre, 38 (34): 158-159.

Rada y Delgado, J. de D. de la e Hinojosa, E. (1878): "Los Nuevos Bronces de Osuna". Museo Español de Antigüedades, 8: 115-174.

Rada y Delgado, J. de D. de la [y Mélida, J.R.] (1883): Catálogo del Museo Arqueológico Nacional, que se publica siendo Director del mismo el Excmo. Señor Don Antonio García Gutiérrez, con la colaboración de los facultativos. Sección primera. Tomo I. Imprenta de Fortanet. Madrid.

Rada, J. de D. de la; [Vives, A. y Codera, F.] (1892): Catálogo de monedas arábigas españolas que se conservan el Museo Arqueológico Nacional publicado siendo Director del mismo D. Juan de Dios de la Rada y Delgado. Establecimiento tipográfico de Fortanet. Madrid.

Ramallo Ortiz, J.A. (1976): Catálogo de los profesores de la Universidad de Granada (1845-1935). Universidad de Granada. Granada.

Ramírez de las Casas Deza, L. (1977): Biografía y Memorias especialmente literarias de Don Luis María Ramírez de las Casas Deza. Córdoba. 
Rasilla Vives, M. de la (2000): Comisión de Antigüedades de la Real Academia de la Historia. Asturias. Catálogo e Índices. Real Academia de la Historia. Madrid.

Remesal, J.; Aguilera, A. y Pons, L. (2000): Comisión de Antigüedades de la Real Academia de la Historia. Cataluña. Catálogo e Índices. Real Academia de la Historia. Madrid.

Renero Arribas, V.M. (2004): "Manuel de Assas y Ereño". En M. Ayarzagüena y G. Mora (eds.): Pioneros de la Arqueología en España del siglo XVI a 1912. Zona Arqueológica, 3: 95-101.

Revilla y Moreno, M. de la (1876): "Revista científica”. Revista Contemporánea, 1: 128 y 3: 383-384.

Revulta Tubino, M. (1989): "Un académico olvidado: Francisco María Tubino, a los cien años de su muerte (1833-1888)". Academia. Boletín de la Real Academia de Bellas Artes de San Fernando, 68: 61-101.

Riaño y Montero, J.F. (1869): Crónica general de D. Alonso el Sabio, y los elementos que concurren á la cultura de la época. Discursos leídos ante la Academia de la Historia en la recepción pública de Don Juan Facundo Riaño el día 10 de octubre de 1869. Imprenta y Estereotipia de M. Rivadeneyra. Madrid.

Riaño y Montero, J.F. (1872): "Antiquities of Yecla". Athenaeum, 2: 23.

Riaño y Montero, J.F. (1876): Programa de la Historia de las Bellas Artes impartida por Juan Facundo Riaño. Escuela Superior de Diplomática especial del cuerpo facultativo de Archiveros, Bibiotecarios y Anticuarios. Universidad Central. Imprenta de T. Fortanet. Madrid.

Riaño y Montero, J.F. (1879): The Industrial Arts in Spain. South Kensington Museum Art Handbooks. Chapman \& Hall. Bradbury Agnew \& Co. printers. London.

Riaño y Montero, J.F. (1880): Los orígenes de la arquitectura arábiga, su transición en los siglos XI y XII y su florecimiento inmediato. Discursos leídos ante la Real Academia de Bellas Artes de San Fernando en la recepción pública de D. Juan Facundo Riaño y Montero, el 16 de mayo de 1880. Contestación por D. Pedro de Madrazo. Real Academia de Bellas Artes de San FernandoArribau y Cia. Madrid.

Riaño y Montero, J.F. (1884): “La Alhambra. Estudio crítico de las descripciones antiguas y modernas del palacio árabe". Revista de España, 97 (385): 525 y 97 (386): 183-207.

Riaño y Montero, J.F. (1895): "Inscripción asiria". Boletín de la Real Academia de la Historia, 27 (4): 264-266.
Ribeiro, C. (1873): "Sur des silex taillés découverts dans les terrains miocène et pliocène du Portugal". $6^{\grave{e ̀ m e}}$ Congrès International d'Anthropologie et d'Archéologie Préhistoriques (Bruxelles, 1872). C. Muquardt, éditeur. Bruxelles: 95-98.

Ribeiro, C. (1878-80): Estudos prehistóricos em Portugal. Noticia de algumas estações e monumentos prehistoricos. Typografia da Academia Real das Sciencias de Lisboa. Lisboa.

Ribeiro, C. (1884): "Les Kjoekkenmoeddings de la vallée du Tage". 9ème Congrès International d'Anthropologie et d'Archéologie Préhistoriques (Lisboa, 1880). Académie Royale des Sciences. Lisbonne: 279-290.

Ríos y Ríos, A. de los (1889): “Campamentos romanos de Julióbriga". Boletín de la Real Academia de la Historia, 14 (6): 509-514.

Ríos y Serrano, D. de los (1875): "Itálica. Últimos descubrimientos de 1874". La Ilustración Española y Americana, 19 (2): 34-35, 19 (5): 83-86 y 19 (8): 134.

Ríos y Serrano, D. de los (1879): Itálica. Historia y descripción artística de esta infortunada ciudad. Ms. 22.283. Biblioteca Nacional. Madrid.

Ríos y Serrano, J. Amador de los (1863): "Algunas consideraciones sobre la estatuaria, durante la monarquía visigoda". El Arte en España, 2: 13-18.

Ríos y Serrano, J. Amador de los (1867): "La arqueología prehistórica en la Real Academia de la Historia". Revista de Bellas Artes e HistóricoArqueológica, 13 de octubre, 2 (53): 20-29.

Ríos y Serrano, J.A. de los; Rada y Delgado, J. de D. de la y Rosell, C. (1860-64): Historia de la Villa y Corte de Madrid. I-IV. Imprenta Ferrá de Mena. Madrid.

Ripoche y Torrens, D. (1883): "Carta de París: La Cueva Pintada de Gáldar”. El Liberal, Las Palmas de Gran Canaria, 4-12-1883.

Rivero Godoy, F.Ma . (1881): Gramática elemental del sánscrito clásico. Imprenta Enrique Teodoro. Madrid.

Roca, P. (1898): "Noticias de la vida y obras de don Pascual de Gayangos". Revista de Archivos, Bibliotecas y Museos, $3^{\text {a }}$. S., 2 (1): 13-22, 2 (2): 7082, 2 (3): 110-130, 2 (12): 562-568.

Rodríguez de Berlanga y Rosado, M. (1873): Los bronces de Osuna. Imprenta de Ambrosio Rubio y Alonso Cano. Málaga.

Rodríguez de Berlanga y Rosado, M. (1876): Los nuevos bronces de Osuna. Imprenta de Ambrosio Rubio. Málaga.

Rodríguez de Berlanga y Rosado, M. (1881a): Hispaniae Anteromanae Syntagma. Los bronces de Lascuta, Bonanza y Aljustrel. I. Imprenta de Ambrosio Rubio. Málaga: 1-399. 
Rodríguez de Berlanga y Rosado, M. (1881b): "Acuñaciones tartesias". En M. Rodríguez de Berlanga, Hispaniae Anterromanae Syntagma. Los bronces de Lascuta, Bonanza y Aljustrel. I. Imprenta de Ambrosio Rubio. Málaga: 400-445.

Rodríguez de Berlanga y Rosado, M. (1881c): Hispaniae Anteromanae Syntagma. Los bronces de Lascuta, Bonanza y Aljustrel. II. Imprenta de Ambrosio Rubio. Málaga: 477-542, 543-622 y 625-830.

Rodríguez de Berlanga y Rosado, M. (1891): El nuevo bronce de Itálica. Imprenta de Ambrosio Rubio. Málaga.

Rodríguez de Berlanga y Rosado, M. (1902): “De algunos manuales de numismática clásica". Revista de la Asociación Artístico Arqueológica Barcelonesa, 4 (32): 573-591 y 4 (33): 657-677.

Rodríguez de Berlanga y Rosado, M. (1903a): Catálogo del Museo de los Excelentísimos Señores Marqueses de Casa-Loring. Gilbert. MálagaBruxelles.

Rodríguez de Berlanga y Rosado, M. (1903b): “Tres objetos malacitanos de época incierta". Bulletin Hispanique, 5 (3): 213-230.

Rodríguez-Ferrer, M. (1880): “Apuntes de un diario. La llegada. Torrelavega. La Cueva de Altamira". La Ilustración Española y Americana, 24 (37): 206-207 y 210.

Rodríguez Oliva, P. (1991): "Manuel Rodríguez de Berlanga (1825-1909): Notas sobre la vida y la obra un estudioso andaluz del mundo clásico". En J. Arce y R. Olmos (eds.): Historiografía de la Arqueología y de la Historia Antigua en España (siglos XVIII-XX) (Madrid, 1988). Ministerio de Cultura. Madrid: 99-106.

Romero Recio, M. (2007): "La Arqueología en la enseñanza española durante el siglo XIX: nuevas aportaciones a la luz de documentos inéditos”. En J. Beltrán (eds.): Arqueología, Coleccionismo y Antigüedad: España e Italia en el siglo XIX (Sevilla, 2004). Universidad de Sevilla. Sevilla: 581-601.

Ronzón, E. (1991): Antropología y antropologías. Ideas para una historia crítica de la antropología española. El siglo XIX. Pentalfa Ediciones. Oviedo.

Ruiz Cabriada, A. (1958): Bio-Bibliografía del Cuerpo Facultativo de Archiveros, Bibliotecarios y Arqueólogos. 1858-1958. Junta Técnica de Archivos, Bibliotecas y Museos. Madrid.

Saavedra y Moragas, E. (1869): Discursos leídos ante la Academia de la Historia en la recepción pública de Don Juan Facundo Riaño el día 10 de octubre de 1869. Contestación del Illmo. Sr. D. Eduardo Saavedra, individuo de número. Imprenta $\mathrm{y}$ Estereotipia de M. Rivadeneyra. Madrid.
Saavedra y Moragas, E. (1883): "Discurso en elogio de D. Adolfo Rivadeneyra". Boletín de la Real Sociedad Geográfica de Madrid, 12 (2): 495-513.

Sáez del Caño, T. (1871): "Las antigüedades del Cerro de los Santos". Revista de Archivos, Bibliotecas y Museos, 1: 317-319.

Salas Álvarez, J. de la A. (2000): "La Sociedad Arqueológica de Excavaciones de Osuna". En V. Oliveira Jorge (ed.): $3^{\circ}$ Congresso de Arqueologia Peninsular. I. Arqueologia Peninsular. História, teoria y prática (Vila Real, 1999). Adecap. Porto: 291-300.

Salas, J. y Beltrán Fortes, J. (2008): "La labor de las Comisiones Científicas del Museo Arqueológico Nacional en Osuna (Sevilla) en 1875 y 1876. Trabajos arqueológicos de Juan de Dios de la Rada y de Francisco Mateos-Gago". En G. Mora, C. Papí y M. Ayarzagüena (eds.): Documentos inéditos para la historia de la arqueología (Madrid, 2007). Memorias de la Sociedad Española de Historia de la Arqueología, 1. Madrid-Toledo: 241-256.

Salavert, V., Pelayo, F. y Gozalo, R. (2003): Los inicios de la prehistoria en la España del siglo XIX: Juan Vilanova y Piera y el origen y antigüedad del hombre. Fundación Marcelino Botín-Universitat de València-Consejo Superior de Investigaciones Científicas. CD-rom. València.

Sales y Ferré, M. (1880): Prehistoria y origen de la civilización. Tomo I. Edad paleolítica. Imprenta Francisco Álvarez y Compañía. Sevilla.

Sales y Ferré, M. (1881): El hombre primitivo y las tradiciones orientales. La Ciencia y la Religión. Conferencias dadas en el Ateneo de Sevilla. Biblioteca Científico-Literaria. El Mercantil Sevillano. Sevilla.

Sales y Ferré, M. (1883-86): Compendio de Historia Universal. Edad prehistórica y período oriental. III. Imprenta Francisco Álvarez y Francisco Tello. Madrid.

Sales y Ferré, M. (1887): Estudios arqueológicos e históricos. Necrópolis de Carmona. Funerales romanos y sus creencias acerca del alma y de otra vida. Sarcófago visigodo de Écija. Excursión al Aljarafe. Victoriano Suárez. Madrid.

Sales y Ferré, M. (1889): Estudios de Sociología. Evolución social y política. I. Victoriano Suárez. Madrid.

Sales y Ferré, M. (1894-97): Tratado de Sociología. Evolución social y política. II-IV. Victoriano Suárez. Madrid.

Sampayo, P. y Zuaznavar, M. (1868): Descripción con planos de la cueva llamada de Atapuerca. Imprenta de D. Timoteo Arnaiz. Burgos.

Sánchez Arteaga, J. (2005): “Eduardo Boscá Casanoves y la renovación taxonómica de los catá- 
logos faunísticos en España durante el último tercio del siglo XIX”. Asclepio, 57 (2): 81-108.

Sanpere i Miquel, S. (1880): “Contribución al estudio de la religión de los iberos". Revista de Ciencias Históricas, 2: 1-45.

Sanpere i Miquel, S. (1881): “Contribución al estudio de los monumentos megalíticos ibéricos". Revista de Ciencias Históricas, 2: 434-519.

Sanz de Sautuola y Pedrueca, M. (1880): Breves apuntes sobre algunos objetos prehistóricos de la provincia de Santander. Imprenta y Litografía de Telesforo Martínez. Santander.

Sanz de Sautuola y Pedrueca, M. (1880/1976): Breves apuntes sobre algunos objetos prehistóricos de la provincia de Santander. B. Madariaga de la Campa (ed.): Marcelino Sanz de Sautuola. Escritos y Documentos. Institución Cultural de Cantabria de la Diputación Provincial. Santander: 69-104.

Sanz del Río, J. (1850): Lecciones sobre el sistema de la Filosofía analítica. Primera, segunda y tercera lección. Imprenta de los sucesores de Andrés Díaz. Madrid.

Sanz-Pastor y Fernández de Pierola, C. (1967): "Origen y evolución histórica de la sección de Museos del Cuerpo Facultativo de Archiveros, Bibliotecarios y Arqueólogos". Revista de Archivos, Bibliotecas y Museos, $4^{\text {a }}$ S., 74 (1-2): 75 104.

Sarmento, M.F. Martins (1879): Observaçoes á Citânia do Snr. Doutor Emilio Hübner. Tipographia de Antonio José da Silva Teixeira. Porto.

Sarmento, M.F. Martins (1880): Os lusitanos: questões d'ethnología. Typographia de Antonio José da Silva Teixeira. Porto.

Sarmento, M.F. Martins (1884): "Les Lusitaniens".

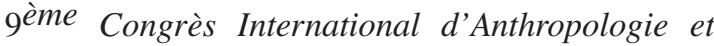
d'Archéologie Préhistoriques (Lisboa, 1880). Académie Royale des Sciences. Lisbonne: 393-431.

Savirón y Esteban, P. (1873): "Estatua de piedra procedente del Cerro de los Santos en la provincia de Albacete". Revista de Archivos, Bibliotecas y Museos, $1^{\text {a }}$ S., 3 (12): 177-180.

Savirón y Esteban, P. (1875): "Noticia de varias excavaciones del Cerro de los Santos en el término de Montealegre". Revista de Archivos, Bibliotecas y Museos, $1^{\text {a }}$ S., 5 (8): 125-129, 5 (10): 161-164, 5 (12): 193-197, 5 (14): 229-234 y 5 (15): 245-247.

Seco Álvarez, M. (2009): "Eduardo Toda y la tumba de Sennedjem". En Ma .C. Pérez Die y W. al-Sadiik (eds.): 120 años de arqueología española en Egipto. 120 years of Spanish Archaeology in Egypt. Sociedad Estatal de Conmemoraciones Culturales. Madrid: 30-33.
Señán y Alonso, E. (1915): Ensayo biográfico-crítico del Excmo. Señor D. Aureliano FernándezGuerra y Orbe. Discurso leído en la solemne inauguración del curso académico de 1915 a 1916 por el Señor Doctor D. Eloy Señán y Alonso, catedrático de Lengua y Literatura Españolas y Decano de la Facultad de Filosofía y Letras. Universidad de Granada. Tipografía de López Guevara. Granada.

Sentenach y Cabañas, N. (1901): "D. Juan de Dios de la Rada y Delgado". Revista de Archivos, Bibliotecas y Museos, 5: 638-645.

Silva, J. Possidónio da (1875): "Uma Necrópole Romana en Portugal". Boletim Architectonico e da Archaeologia da Real Associaçao de Arquitectos Civis e Arqueólogos Portugueses, 1 (6): 91.

Silva, J. Possidónio da (1878): Noções elementares de archeologia. Lallemant frères. Lisboa.

Silva, J. Possidónio da (1884): "Sur les haches en bronze trouvées en Portugal". 9ème Congrès International d'Anthropologie et d'Archéologie Préhistoriques (Lisboa, 1880). Académie Royale des Sciences. Lisbonne: 358-363.

Silva, J. Possidonio da (1887): "Sobre a necrópole de Alcácer do Sal". Boletim Architectonico e da Archaeologia da Real Associaçao de Arquitectos Civis e Arqueólogos Portugueses, 1887.

Simoes, A.F. (1878): Introducçao a Archeologia da Peninsula Iberica. Antiguidades prehistoricas. Livraria Ferreira. Lisboa.

Simonet y Baca, F.J. (1891): Memoria presentada al IX Congreso Internacional de Orientalistas celebrado en Londres en septiembre de 1891. Breve noticia de los Orientalistas que ha producido la Universidad de Granada. La mujer arábigo-española. El dialecto hispano-mozárabe. Imprenta J.L. Guevara. Granada.

Sociedad Antropológica Española (1865): Estatutos y Reglamento de la Sociedad Antropológica Española. Imprenta de J.M. Ducazcal. Madrid.

Sociedad Antropológica y Etnográfica Española (1880): Estatutos y Reglamento de la Sociedad Antropológica y Etnográfica Española. Imprenta Central á cargo de Victor Saiz. Madrid.

Solano y Eulate, J. (1880): Relaciones entre la Geología y la Revelación. Discurso pronunciado en la solemne inauguración del año académico de 1880 á 1881 en la Universidad Central. Madrid.

Toda y Güell, E. (1886): Sesostris. Tipografía de Manuel Ginés Hernández. Madrid.

Toda y Güell, E. (1887a): "Son notém en Tebas. Inventario y texto de un sepulcro egipcio de la XX dinastía". Boletín de la Real Academia de la Historia, 10: 91-148. 
Toda y Güell, E. (1887b/1916): Catálogo de la Colección Egipcia. Biblioteca-Museo Balaguer. Imprenta de Manuel Tello. Madrid.

Toda y Güell, E. (1887c): La Muerte en el Antiguo Egipto. Tipografía de Manuel Ginés Hernández. Madrid.

Toda y Güell, E. (1889): "Las Momias Reales de Bulaq". En G. Rawlison, Historia del Antiguo Egipto. Trad. E. Toda. Madrid.

Tortosa, T. y Mora, G. (1996): "La actuación de la Real Academia de la Historia sobre el patrimonio arqueológico: ruinas y antigüedades". Archivo Español de Arqueología 69 (173-174): 191-217.

Trigueros Gordillo, G. (1998): La Universidad de Sevilla durante el Sexenio revolucionario. Universidad de Sevilla. Sevilla.

Trusted, M. (2006): "In all cases of difference adopt Signor Riaño's view. Collecting Spanish decorative arts at South Kensinton in the late nineteenth century". Journal of the History of Collections, 2006: $1-12$.

Truyols Santonja, J. (1993): “La geología española en la época de Juan Vilanova y Piera”. Homenaje a Juan Vilanova y Piera 1883-1993. Geología, Paleontología y Prehistoria en el siglo XIX (Valencia, 1993). Real Sociedad Económica de Amigos del País de Valencia. Valencia: 213-228.

Tubino y Oliva, F.M ${ }^{\mathrm{a}}$. (1868a): Estudios prehistóricos. Cuaderno I. Oficinas de la 'Revista de Bellas Artes'. Madrid.

Tubino y Oliva, F.Mª (1868b): "Monumento prehistórico de Castilleja de Guzmán”. Estudios prehistóricos. Cuaderno I. Oficinas de la "Revista de Bellas Artes'. Madrid: 49-59.

Tubino y Oliva, F.M" . (1870a): "El hombre terciario". La Ilustración Española y Americana, 10 de abril, 14 (8): 115-117.

Tubino y Oliva, F.M . (1870b): "Recientes publicaciones sobre la ciencia prehistórica. Huxley, De la place de l'homme dans la nature; Büchner, Conférences sur la théorie darwinienne, application de cette doctrine à l'homme; Royer, Origine de l'homme et des sociétés; Figuier, L'homme primitif'. Boletín-Revista de la Universidad de Madrid, 2: 956-966 y 1058-1068.

Tubino y Oliva, F.M" (1872): "Primera parte. El origen de las especies. Antecedentes de la teoría de Darwin. Segunda parte. El origen del hombre según Darwin”. En J. Vilanova (ed.): La Creación. Historia Natural. I-VIII. Imprenta de Montaner y Simón. Barcelona: i-lxx.

Tubino y Oliva, F.M'. (1874): "Darwin y Haeckel. Antecedentes de la teoría de Darwin". Revista de Antropología, 1: 238-256, 356-, 401- y 481-.
Tubino y Oliva, J.Mª (1875): "Monuments mégalithiques de l'Andalousie". 4ème Congrès International d'Anthropologie et d'Archéologie Préhistoriques (Copenhague, 1869). Imprimerie de Thiele. Copenhague: 93-97.

Tubino y Oliva, F.M" (1876): "Los monumentos megalíticos de Andalucía, Extremadura y Portugal y los aborígenes ibéricos". Museo Español de Antigüedades, 7: 303-364.

Tubino y Oliva, F.M' (1886): Estudios sobre el arte en España. La arquitectura hispano-visigoda y árabe española. El Alcázar de Sevilla. Una idea mozárabe. Imprenta La Andalucía. Sevilla.

Tuñón de Lara, M. (1960/1973): La España del siglo XIX. Editorial Laia. Barcelona.

Tuñón de Lara, M. (1970/1982): Medio siglo de cultura española. Bruguera. Barcelona.

Tuñón de Lara, M. (1999): "Historia Contemporánea". En M. Tuñón de Lara (ed.): Historia de España. Ámbito ediciones. Valladolid: 389-636.

Urigüen González, Mª .B. (1986): Orígenes y evolución de la derecha española: el neo-catolicismo. Consejo Superior de Investigaciones Científicas. Madrid.

Urquinaona y Bidot, J.M' (1876): Carta pastoral que el Ilmo. y Rmo. Sr. D. José María de Urquinaona, obispo de Canarias y administrador apostólico de Tenerife dirige al clero y fieles de ambas diócesis, con motivo de la obra, que ha empezado a publicarse en esta ciudad, con el título de 'Estudios históricos, climatológicos y patológicos de las Islas Canarias', prohibiendo su lectura. Victor Doreste. Las Palmas.

Valverde y Perales, F. (1903): "D. José Amador de los Ríos". Historia de la Villa de Baena. Imprenta y librería de la Viuda e hijos de J. Peláez. Toledo: 418-433.

Vargas-Zúñiga, A., Marqués de Siete Iglesias (1978): "Real Academia de la Historia. Catálogo de sus individuos. Noticias sacadas de su archivo.". Boletín de la Real Academia de la Historia, 175 (1): 19-105, 175 (2): 309-352 y 175 (3): 533-574.

Vargas-Zúñiga, A., Marqués de Siete Iglesias (1979): "Real Academia de la Historia. Catálogo de sus individuos. Noticias sacadas de su archivo.". Boletín de la Real Academia de la Historia, 176 (1): 7-33, 176 (2): 288-365 y 176 (3): 499-538.

Vargas-Zúñiga, A., Marqués de Siete Iglesias (1981): Real Academia de la Historia. Catálogo de sus individuos. Noticias sacadas de su archivo. I. Académicos de Número. Real Academia de la Historia. Madrid.

Vasconcelos, J. de Leite de (1885): Portugal pre-histórico. Biblioteca do Povo e das Escolas, 106. Lisboa. 
Veiga, S.P.M. Estácio da (1886-91): Antiguidades Monumentaes do Algarve. Tempos prehistoricos. IIV. Imprensa Nacional. Lisboa.

Verde Casanova, A.M" (1980): "La primera sociedad antropológica de España”. I Congreso Español de Antropología. II. Madrid: 17-37.

Verneau, R. (1886): "La race de Cro-Magnon. Ses migrations, ses descendants". Revue d'Anthropologie, $3^{\mathrm{a}}$ S., 1: 10-24.

Verneau, R. (1886/1996): "La raza de Cromañón. Sus emigraciones, sus descendientes". A través del tiempo, 14. J.A.D.L. La Laguna-La Orotava: 7-27.

Verneau, R. (1887): Rapport sur une mission scientifique dans l'Archipiel Canarien. Imprimerie Nationale. Paris. Archives des Missions scientifiques et littéraires, $3^{\mathrm{a}}$ série, 13: 569-817.

Verneau, R. (1891): Cinq années de sejour aux Iles Canaries. Imprimerie Hannuyer. Paris.

Verneau, R. (1891/1981): Cinco años de estancia en las Islas Canarias. A través del tiempo, 1. Ediciones J.A.D.L. Madrid-La Orotava.

Verneuil, J. y Lartet, J.L. (1863): "Note sur un silex taillé trouvé dans le diluvium des environs de Madrid". Bulletin de la Société Geologique de France, 20: 698-702.

Vilanova y Piera, J. (1859): Memoria Geognósticaagrícola sobre la provincia de Castellón. Memoria de la Real Academia de Ciencias. Madrid.

Vilanova y Piera, J. (1860-61): Manual de Geología aplicada a la agricultura y a las artes industriales. I-II. III atlas. Imprenta Nacional. Madrid.

Vilanova y Piera, J. (1863/2012): "Sobre lenguaje geológico. Prado". En F. Pelayo y R. Gozalo, Juan Vilanova y Piera (1821-1893), la obra de un naturalista y prehistoriador valenciano. La donación Masiá Vilanova en el Museo de Prehistoria de Valencia. Trabajos Varios del Servicio de Investigación Prehistórica, 114. Diputación de Valencia. Valencia: 290-294.

Vilanova y Piera, J. (1868): "Conferencias del Ateneo. El hombre fósil". Revista de Bellas Artes é Histórico-Arqueológica, 3 (68): 264-266, 3 (69): 281-282, 3 (71): 313-315 у 378-379.

Vilanova y Piera, J. (1869a): "Prehistoric Remains in Valencia". $3^{\text {rd }}$ International Congress of Prehistoric Archaeology (Norwich-London, 1868). Longmans, Green and Co. London: 398-400.

Vilanova y Piera, J. (1869b): “Origen y antigüedad del hombre". Boletín-Revista de la Universidad de Madrid, 1 (5): 233-247, 1 (9): 449-462 y 1 (12) 641-663.

Vilanova y Piera, J. (1870): Ensayo de descripción geognóstica de la provincia de Teruel en sus relaciones con la agricultura de la misma. Imprenta Nacional. Madrid.
Vilanova y Piera, J. (1872a): Origen, Naturaleza y Antigüedad del Hombre. Imprenta de la Cía. de Impresores y Libreros del Reino. Madrid.

Vilanova y Piera, J. (1872b): "Lo prehistórico en España”. Anales de la Sociedad Española de Historia Natural, 1: 187-229.

Vilanova y Piera, J. (ed.) (1872-76): La Creación. Historia Natural. I-VIII. Imprenta de Montaner y Simón. Barcelona.

Vilanova y Piera, J. (1874): “Origen, antigüedad y naturaleza del hombre". Revista de Antropología, 1 (1): 53-64, 1 (2): 125-136 y 1 (3): 185-203.

Vilanova y Piera, J. (1875a): "Découvertes archéologiques préhistoriques faites en Espagne". $4^{\grave{e ̀ m e}}$ Congrès International d'Anthropologie et d'Archéologie Préhistoriques (Copenhague, 1869). Imprimerie de Thiele. Copenhague: 221-234.

Vilanova y Piera, J. (1875b): "El hombre terciario". Revista Europea, 6: 86.

Vilanova y Piera, J. (1876a): "Sur les études préhistoriques en Espagne". $7^{\text {ème }}$ Congrès International d'Anthropologie et d'Archéologie Préhistoriques (Stockholm, 1874). P.A. Norstedt \& Söner. Stockholm: 838-839.

Vilanova y Piera, J. (1876b): "La doctrina de Darwin". Revista Europea, 7: 356-358.

Vilanova y Piera, J. (1876c): "La cátedra de prehistoria en el Ateneo y su censor Revilla". Revista Europea, 8: 219-223.

Vilanova y Piera, J. (1876d): "Horizonte superior del corte de San Isidro". Anales de la Sociedad Española de Historia Natural, 5: 45-46.

Vilanova y Piera, J. (1877): "Sur les études préhistoriques en Espagne". 8ème Congrès International d'Anthropologie et d'Archéologie Préhistoriques (Budapest, 1876). Imprimerie Franklin-Tarsulat. Budapest: 838-839.

Vilanova y Piera, J. (1881a): Conferencias dadas en Santander. Imprenta de Bernardo Rueda. Torrelavega, Santander.

Vilanova y Piera, J. (1881a/1997): Conferencias dadas en Santander. O. Cendrero Uceda (ed.). Universidad de Cantabria-Ayuntamiento de Santillana del Mar. Santander.

Vilanova y Piera, J. (1881b): "Viaje á Argelia y á la provincia de Almería". Actas de la Sociedad Española de Historia Natural, 10: 27-35.

Vilanova y Piera, J. (1883): "Sur la caverne de Santillana". $11^{\text {ème }}$ Congrès de l'Association française pour l'avancement des sciences (La Rochelle, 1882). Secrétariat de l'Association française pour l'avancement des sciences. Paris: 669-673.

Vilanova y Piera, J. (1884a): "De cuivre et du bronze en Espagne et de la période qui les a précédés". gème Congrès International d'Anthropologie et 
d'Archéologie Préhistoriques (Lisboa, 1880). Académie Royale des Sciences. Lisbonne: 352354.

Vilanova y Piera, J. (1884b): Los Congresos Científicos de Chalons [1876], Berna [1878], París [1878], Lisboa [1880] y Argel [1881]. Imprenta del Colegio Nacional de Sordo-Mudos y de Ciegos. Madrid.

Vilanova y Piera, J. (1884c): “Cueva próxima á Alcoy". Actas de la Sociedad Española de Historia Natural, 13: 97.

Vilanova y Piera, J. (1886a): “Congresos de Ginebra y Nancy". Actas de la Sociedad Española de Historia Natural, 15: 76-80.

Vilanova y Piera, J. (1886b): "Los dibujos y pinturas de la cueva de Santillana". Actas de la Sociedad Española de Historia Natural, 15: 89-91.

Vilanova y Piera, J. (1889a): Historia del planeta. Síntesis abreviada de los positivos documentos de la primitiva especie de España hasta el presente descubiertos. Discursos leídos en la Real Academia de la Historia en la recepción pública del Dr. Don Juan Vilanova y Piera, el día 29 de junio de 1889. Imprenta de A. Pérez Dubrull. Real Academia de la Historia. Madrid.

Vilanova y Piera, J. (1891): "Questions touchant l'archéologie en Espagne". 10ème Congrès International d'Anthropologie et d'Archéologie Préhistoriques (Paris, 1889). Ernest Leroux, éditeur. Paris: 250-252.

Vilanova y Piera, J. (1893): Memoria Geognósticoagrícola y protohistórica de Valencia. Establecimiento Tipográfico de Fontanet. Madrid.

Vilanova, J. y Rada, J. de D. de la (1893): Geología y Proto-historia ibéricas. En A. Cánovas del Castillo (ed.): Historia General de España. Real Academia de la Historia. El Progreso Editorial. Madrid.

Vilanova, J. y Tubino, F.Mª (1868): “Exploración geológico-arqueológica de Cerro Muriano”. En F. Tubino, Estudios prehistóricos. Cuaderno I. Oficinas de la 'Revista de Bellas Artes'. Madrid: 97-106.

Vilanova, J. y Tubino, F.M (1871): Viaje científico a Dinamarca y Suecia con motivo del Congreso Internacional Prehistórico celebrado en Copenhague en 1869. Imprenta de A. Gómez Fuentenebro. Madrid.
Villa-Amil y Castro, J. (1867): Rudimentos de arqueología sagrada. Imprenta de Soto Freire. Lugo.

Villa-Amil y Castro, J. (1873): Antigüedades prehistóricas y célticas de Galicia ( $1^{a}$. Parte). Imprenta Soto Freire. Lugo.

Villa-Amil y Castro, J. (1874): “Adornos de oro encontrados en Galicia". Museo Español de Antigüedades, 3: 545-555.

Villa-Amil y Castro, J. (1875): “Armas, utensilios y adornos de bronce recogidos en Galicia”. Museo Español de Antigüedades, 4: 59-71.

Villa-Amil y Castro, J. (1876): "Castros y mamoas de Galicia”. Museo Español de Antigüedades, 7: 195237.

Villares, R. (2009): “Alfonso XII y Regencia”. En J. Fontana y R. Villares (eds.): Historia de España. 7. Restauración y Dictadura. Crítica-Marcial Pons. Barcelona: 1-304.

Wallace, A.R. (1889): Darwinism: An Exposition of the Theory of Natural Selection, with Some of its Applications. Macmillan. London.

Zapata Parra, J.A. (2004): "Rodrigo Amador de los Ríos: la defensa del patrimonio y la arqueología". Revista Arqueomurcia, 2: 1-70.

Zobel de Zangróniz, J. (1866): "Noticia de varios monumentos que demuestran la existencia de un alfabeto desconocido empleado antiguamente en alguna de las regiones meridionales de la Bética". En A. Campaner (ed.): Memorial Numismático Español: colección de trabajos, artículos, etc., sobre la numismática antigua y moderna, especialmente la española, 1 . Establecimiento tipográfico de Narciso Ramírez y Compañía. Barcelona: $7-41$.

Zobel de Zangróniz, J. (1877-79): Estudio histórico de la moneda antigua española desde su origen hasta el Imperio romano. En A. Campaner (ed.): Memorial Numismático Español, 4 (1): 85-289 y 4 (2): 73-208.

Zobel de Zangróniz, J. (1880): Estudio histórico de la moneda antigua española desde su origen hasta el Imperio romano. En A. Campaner (ed.): Memorial Numismático Español, 5: 1-300. 
